\title{
An update to the fatty acid profiles of bovine retail milk in the United Kingdom: implications for nutrition in different age and gender groups
}

Article

Accepted Version

Creative Commons: Attribution-Noncommercial-No Derivative Works 4.0

Stergiadis, S., Berlitz, C. B., Hunt, B., Garg, S., Givens, D. I. and Kliem, K. E. (2019) An update to the fatty acid profiles of bovine retail milk in the United Kingdom: implications for nutrition in different age and gender groups. Food Chemistry, 276. pp. 218-230. ISSN 0308-8146 doi:

https://doi.org/10.1016/j.foodchem.2018.09.165 Available at https://centaur.reading.ac.uk/79463/

It is advisable to refer to the publisher's version if you intend to cite from the work. See Guidance on citing.

To link to this article DOI: http://dx.doi.org/10.1016/j.foodchem.2018.09.165

Publisher: Elsevier

All outputs in CentAUR are protected by Intellectual Property Rights law, including copyright law. Copyright and IPR is retained by the creators or other copyright holders. Terms and conditions for use of this material are defined in the End User Agreement. 


\section{www.reading.ac.uk/centaur}

\section{CentAUR}

Central Archive at the University of Reading

Reading's research outputs online 


\section{An update to the fatty acid profiles of bovine retail milk in the United Kingdom: implications for nutrition in different age and gender groups}

\section{Running title: Fatty acid profile of UK retail milk and dietary intake implications}

Sokratis Stergiadis*a, Carolina B. Berlitz ${ }^{\mathrm{a}, \mathrm{b}}$, Benjamin Hunt ${ }^{\mathrm{a}}$, Sneha Garg $^{\mathrm{a}}$, D. Ian Givens ${ }^{\mathrm{c}}$, Kirsty E. Kliem ${ }^{\text {a, c }}$

${ }^{a}$ University of Reading, Animal, Dairy and Food Chain Sciences, School of Agriculture, Policy and Development, PO Box 237, Earley Gate, Reading, RG6 6AR, United Kingdom

b Federal University of Rio Grande do Sul, Department of Animal Science, Av Bento Gonçalves, 7712, Porto Alegre, RS, 91540-000, Brazil.

${ }^{\mathrm{c}}$ University of Reading, Institute for Food, Nutrition and Health, PO Box 237, Earley Gate, Reading, RG6 6AR, United Kingdom

* Corresponding author: Sokratis Stergiadis, s.stergiadis@ reading.ac.uk 
2 This study investigated the effect of UK dairy production system, month, and their interaction, 3 on retail milk fatty acid (FA) profile throughout the year. Milk samples $(n=120)$ from four 4 conventional (CON), four organic (ORG) and two free-range (FR) brands were collected 5 monthly. ORG milk had more nutritionally-desirable polyunsaturated $\mathrm{FA}$, including rumenic 6 acid and the omega-3 PUFA $\alpha$-linolenic, eicosapentaenoic and docosapentaenoic acids, and 7 less of the nutritionally-undesirable palmitic acid. Milk FA profile was similar between FR and 8 CON, but FR milk had less SFA and/or palmitic acid, and/or greater $\alpha$-linolenic and rumenic 9 acids in certain months within the peak-grazing season. According to the measured milk FA 10 profiles and UK milk fat intakes, milk and dairy products contribute around one-third of the 11 maximum recommended saturated FA intake. A small increased intake of beneficial PUFA 12 may be expected by consuming ORG milk but human health implications from such differences 13 are unknown.

14

15 Keywords: milk; dairy management; dietary intakes; fatty acids; free-range; human health; 16 omega-3; organic 
Milk and dairy products provide a range of beneficial nutrients for human health, including fatty acids (FA), proteins, bioactive peptides, minerals, carotenoids and vitamins (Haug, Hostmark, \& Harstad, 2007; Pereira, 2014; Thorning, et al., 2017). However, milk and dairy products are dietary sources of saturated fatty acids (SFA), such as C12:0, C14:0 and C16:0, elevated consumption of which may increase the risk of cardiovascular disease (CVD) (EFSA, 2010; FAO, 2010). These concerns and the increased incidence of lifestyle-related diseases, such as obesity and CVD, may have contributed to the reduction in whole milk consumption in developed countries, including UK, Denmark, France, USA, Canada and Germany (Kliem \& Givens, 2011). In the UK, whole milk consumption has decreased 5-fold compared with 1970s' levels, and despite the simultaneous increase in semi-skimmed milk consumption, the overall milk intake has declined (Kliem, et al., 2011). In contrast, milk is also rich in FA with potentially beneficial effects on human health (see reviews from (Barcelo-Goblijn \& Murphy, 2009; Dilzer \& Park, 2012; Field, Blewett, Proctor, \& Vine, 2009; Haug, et al., 2007; Swanson, Block, \& Mousa, 2012)), such as the monounsaturated FA (MUFA) t11 C18:1 (VA, vaccenic acid) and c9 C18:1 (OA, oleic acid), the polyunsaturated FA (PUFA) c9c12c15 C18:3 (ALNA, $\alpha$-linolenic acid), c5c8c11c14c17 C20:5 (eicosapentaenoic, EPA), c7c10c13c16c19 C22:5 (docosapentaenoic, DPA) and c4c7c10c13c16c19 C22:6 (docosahexaenoic acid, DHA), which are omega-3 PUFA (n-3), the c9c12 C18:2 (LA, linoleic acid), which is an omega-6 PUFA (n6), and the conjugated FA c9t11 C18:2 (RA, rumenic acid) (Kliem \& Shingfield, 2016; Pereira, 2014).

Current nutritional recommendations are to reduce SFA consumption (as low as possible and not exceeding $10 \%$ of total energy intake) and substitute dietary SFA with MUFA and/or PUFA (EFSA, 2010; FAO, 2010). Previous research has shown that dairy management, and especially 
higher dietary forage:concentrate ratio, and/or diets supplemented with plant oils, oilseeds or protected lipids may produce milk with a FA profile that contains less SFA and more n-3 and RA (Chilliard, Glasser, Ferlay, Bernard, Rouel, \& Doreau, 2007; Elgersma, 2015; Kliem, et al., 2016). Therefore, potential differences between different dairy production systems, which involve differences in cow nutrition, may reflect on milk FA composition. In the UK, organic milk contained greater concentrations of ALNA, EPA and n-3 PUFA all year round, and less SFA in milk fat, including C16:0, during summer, when compared with conventional milk (Butler, Stergiadis, Seal, Eyre, \& Leifert, 2011b; Stergiadis, et al., 2012). A seasonal effect on milk FA composition has been previously demonstrated in UK retail milk (Kliem, Shingfield, Livingstone, \& Givens, 2013), which also influences the extent of the compositional differences between organic and conventional milk (Butler, et al., 2011b). However, the interaction between production system and season has been assessed only during January and July (Butler, et al., 2011b), which are potentially among the months with the highest difference in pasture intake in UK dairy systems (Stergiadis, et al., 2012), so a more detailed assessment throughout the year is required.

Fresh grass intake strongly influences n-3 PUFA content of milk fat, as recently highlighted in several multivariate redundancy analyses (Stergiadis, et al., 2015a; Stergiadis, et al., 2015b; Stergiadis, et al., 2012). Bulk tank milk from conventional extensive pasture-based farms, (pasture intake contributing more than $90 \%$ of cow dry matter intake), contained more of the 61 potentially nutritionally beneficial, when replacing SFA in human diets, MUFA and/or PUFA and less SFA when compared with conventional and/or organic milk, although differences were not consistent throughout the year or in all studies (Butler, et al., 2008; Stergiadis, et al., 2015b). Recently, free-range milk, certified on farms where cows have access to pasture for a minimum of 180 days/year and being outdoors for a minimum of 23 hours/day during the grazing season, reached the UK market. In the Netherlands, retail milk from dairy farms under a similar 
certification scheme, but with less mandatory access to pasture (minimum 120 days/year at pasture and 6 hours/day), had a similar FA profile to retail conventional milk (Capuano, Gravink, Boerrigter-Eenling, \& van Ruth, 2015) but potential differences under the UK dairy management practices have not yet been investigated.

This study therefore aimed to (i) investigate the effect of production system (conventional, organic and, for the first time in the UK, free-range), month (March through to February) and their interaction, on retail milk FA profile throughout the year, and (ii) assess the potential implications on the intakes of FA which are relevant to human health.

\section{Materials and methods}

\subsection{Experiment/survey design}

All milk samples $(n=120)$ in the present study were collected from retail outlets in England. The survey lasted for 12 months and samples were collected monthly between March 2016 and February 2017. Four brands of conventional milk and four brands of organic milk were sampled monthly from four retail outlets within a $8 \mathrm{~km}$ radius of the University of Reading. The only two brands of free-range-certified milk available to UK consumers during the period of this study were obtained monthly from dairies in Lancashire and Gloucestershire. All retail milk samples were whole, pasteurized and homogenized, while conventional and free-range milk had also their fat content standardized to approximately 3.5 and $3.7 \mathrm{~g} / 100 \mathrm{~g}$ milk, respectively. Milk samples were collected to represent the latest "best before" date, available at the day of sampling, to ensure minimum storage time at retail outlet. Milk samples in commercial packaging were immediately transferred to the laboratories of the University of Reading, and aliquoted into $30-\mathrm{ml}$ sterile polypropylene screw-top containers and were frozen at $-20^{\circ} \mathrm{C}$ until analysis.

\subsection{Milk analysis}


91 Concentrations of fat, protein, casein, and lactose were analysed using a Milkoscan FT6000

92 (Foss Electric, Hillerod, Denmark), while somatic cell count (SCC) was analysed by a 93 Fossomatic (Foss Electric, Hillerod, Denmark), in the National Milk Laboratories 94 (Wolverhampton, UK). Milk FA profiles were analysed by GC flame ionisation detection 95 (Bruker $350 \mathrm{GC}$, Bruker, Germany) according to previously described methods of esterification 96 and methylation (Chilliard, Martin, Rouel, \& Doreau, 2009), and techniques of peak 97 identification and quantification (Kliem, et al., 2013). A combined correction factor, to account 98 for carbon deficiency in the response of flame ionization detector for FA methyl esters with 49910 atoms of carbon was used (Ulberth, Gabernig, \& Schrammel, 1999).

\subsection{Statistical analysis}

101

Analysis of variance (ANOVA), derived from linear mixed effects models (residual maximum likelihood analysis; REML) (Gilmour, Thompson, \& Cullis, 1995) in GenStat (VSN International, $17^{\text {th }}$ Edition, Hempstead, UK), by considering management (Conventional,

104 CON; Organic, ORG; Free-Range, FR) and month (March, April, May, June, July, August, 105 September, October, November, December, January, February), and their interaction, as fixed factors and milk ID (which was unique for each combination of brand/retailer and management) as a random factor. Significant effect of the main treatments was declared when $P<0.05$ and tendencies were declared when $0.05<P<0.10$. The residual diagnostics of the

109 final model were assessed using normality plots, with no data showing deviation from 110 normality except for SCC which were log-transformed prior to ANOVA. Pairwise comparisons 111 of means $(P<0.05)$ were performed using Fisher's Least Significant Difference test. Milk FA 112 profiles are reported as $\mathrm{g} / \mathrm{kg}$ milk fat. Atherogenicity index (AI), thrombogenicity index (TI), 113 as markers to indicate potential risk of CVD, were calculated according to Srednicka-Tober et 114 al. (2016), as follows:

- $\mathrm{AI}=(\mathrm{C} 12: 0+4 \times \mathrm{C} 14: 0+\mathrm{C} 16: 0) /(\mathrm{MUFA}+\mathrm{PUFA})$, 
- $\mathrm{TI}=(\mathrm{C} 14: 0+\mathrm{C} 16: 0+\mathrm{C} 18: 0) /[(0.5 \times$ MUFA $)+(0.5 \times \mathrm{n}-6)+(3 \times \mathrm{n}-3)+(\mathrm{n}-3 / \mathrm{n}-6)]$.

$\Delta^{9}$-desaturase activity index $\left(\Delta^{9} \mathrm{I}\right)$ was calculated according to Kay et al. (2004) as:

$$
\mathrm{C} 16: 0+\mathrm{C} 18: 0+\mathrm{VA})
$$

120 For the purposes of the intake calculations, this study assumes that all dairy products produced

121 in the UK have the same FA profile as the whole milk analysed. Intakes of individual FA or

122 FA groups, for males/females/all for the age groups of 4-10/11-18/19-64/65+ were estimated

123 separately as:

124 FA intake $(\mathrm{g} / \mathrm{d})=$ fat intake $(\mathrm{g} / \mathrm{d})($ Bates, et al., 2014) $\times$ contribution of fat from milk and dairy

125 products $(\%$ of total fat intake) (Bates, et al., 2014) $\times 0.933$ (correction factor representing \%

126 of FA in total milk fat) (Kliem, et al., 2013) $\times$ milk FA concentration (\% of total FA).

\section{Results}

128 All differences discussed in the Results section were statistically significant $(\mathrm{P}<0.05)$ unless 129 otherwise stated.

\subsection{Milk basic composition}

\subsubsection{Effect of production system}

132 Significant effect of production system was identified for milk concentrations of fat and lactose

133 (Table 1). Compared with CON and FR milk, respectively, ORG milk contained more fat and 134 less lactose (Table 1). There were no significant differences in milk composition between CON and FR milk (Table 1).

\subsubsection{Effect of month}

137 Significant effects of month were identified for milk concentrations of all basic composition parameters (Table 2). Milk contained less fat during May-September and December than in 
139 March-April, with the remaining months showing intermediate values, mostly without being

140 significantly different (Table 2). Protein concentrations in milk were higher in May, October

141 and November (highest) than in June-September, December and February, with the remaining

142 months showing intermediate values, mostly without being significantly different (Table 2).

143 Casein concentrations in milk were highest in October-November when compared with all

144 other months, although the difference with May was not statistically significant (Table 2).

145 Highest lactose concentrations were observed in March-May and lowest in July, September,

146 October and December with intermediate values being observed during the other months,

147 mostly without being significantly different (Table 2). Milk had higher SCC during winter

148 (December-February) than in March-November, although the difference with January was not

149 statistically significant (Table 2).

\subsubsection{Effect of the production system $\times$ month interaction}

151 Significant effects of the production system $\times$ month interaction were identified for milk lactose

152 concentrations (Appendix; Figure A1); CON milk had more lactose than ORG and FR milk in

153 June, September and November, and less lactose than FR milk in July.

\subsubsection{Effect of production system}

156 Significant effect of the production system was identified for milk concentrations of C16:0,

157 RA, ALNA, EPA, DPA, PUFA, n-3, and trans FA and the ratios of n-3/n-6, TI, C14:1/C14:0,

158 C16:1/C16:0 and OA/C18:0 (Table 1). Compared with CON and FR milk, respectively, ORG

159 milk had lower concentrations of C16:0 and higher concentrations of RA, ALNA, EPA, DPA, 160 trans MUFA, PUFA, cis PUFA, trans PUFA, cis/trans plus trans/cis PUFA, n-3 and trans FA

161 (Table 1). ORG milk had a higher ratio of $n-3 / n-6$ and lower ratio of TI, C14:1/C14:0,

$162 \mathrm{C} 16: 1 / \mathrm{C} 16: 0$ and OA/C18:0 than CON and FR milk although the difference between ORG and 
163 FR milk for OA/C18:0 ratio was not statistically significant (Table 1). There were no 164 significant differences in FA profile between CON and FR milk (Table 1). The effect of 165 production system in the full FA profile of milk (80 individual FA) is shown in the Appendix 166 (Table A1).

\subsubsection{Effect of month}

Significant effects of month were identified for milk concentrations of all individual FA (except DHA) and FA groups and indices (Table 2). Concentrations of C12:0 in milk fat were lower in June-October than in March-May and November-February, with numerically smaller significant differences between months within these periods also being observed (Table 2).

172 Concentrations of C14:0 and SFA and the AI and TI in milk were lower in May-October than in March and November-February, with numerically smaller significant differences between months within these periods also being observed; their values were intermediate in April and lower when compared with March and November-February (Table 2). Milk contained more

$176 \mathrm{C} 16: 0$ in March and October-February than in May-August and had intermediate 177 concentrations in April and September, which were also lower when compared with October178 February (Table 2). Milk contained more C18:0 in May-September than in March and

179 November-February, and had intermediate concentrations in April and October (Table 2).

180 Concentrations of VA, ALNA and EPA and n-3/n-6 in milk were higher in May-October than 181 in March-April and November-February, with numerically smaller significant differences 182 between months within these periods also being observed (Table 2). OA concentrations and $183 \Delta^{9} \mathrm{I}$ in milk were higher in May-October than in March and November-February, with numerically smaller significant differences between months within these periods also being observed; their values were intermediate in April (Table 2). Milk contained more LA in March-

186 May and October, than in July and November-February, with the remaining months showing 187 intermediate values, mostly without being significantly different (Table 2). RA and trans FA 
concentrations in milk were highest in May-September, lowest in March and November-

189 February, and showed intermediate values in April and October, with numerically smaller

190 significant differences between months within these periods also being observed (Table 2).

191 DPA concentrations in milk were higher in May-November than in March-April and

192 December-February, with numerically smaller significant differences between months within

193 these periods also being observed; the means for these parameters were intermediate in

194 January-February and higher when compared with March-April (Table 2).

195 Concentrations of MUFA, cis MUFA, trans MUFA, PUFA, cis PUFA, trans PUFA, cis/trans

196 plus trans/cis PUFA and n-3 in milk were higher in May-October than in March and

197 November-February, with numerically smaller significant differences between months within

198 these periods also being observed; the means for these parameters were intermediate in April

199 (Table 2). Milk contained more n-6 in March-May and September-October, than in July and

200 November-January, with the remaining months showing intermediate values, mostly without

201 being significantly different (Table 2). When excluding VA, trans FA concentrations in milk

202 were highest in May-July, lowest in September-November, and showed intermediate values in

203 March-April, August and December-February; numerically smaller significant differences

204 between months within these periods were also observed (Table 2).

205 Ratio of C14:1/C14:0 was higher in September-November than in March-June and February,

206 with numerically smaller significant differences between months within these periods also

207 being observed; the means for these parameters were intermediate in July-August and

208 December-January and higher when compared with March-May (Table 2). Ratio of

209 C16:1/C16:0 in milk was highest in May-October, lowest in March and December-February,

210 and showed intermediate values in April and November, with numerically smaller significant

211 differences between months within these periods also being observed (Table 2). Ratio of

212 OA/C18:0 in milk was highest in September-November, lowest in April and December- 
213 February, and showed intermediate values in March and May-August, although the difference 214 between March and April and December-February was not statistically significant; numerically

215 smaller significant differences between months within these periods were also observed (Table

216 2). Milk had higher ratio of RA/VA in June-August and October-December than in May, with

217 the remaining months showing intermediate values, mostly without being significantly

218 different (Table 2). The effect of month in the full FA profile of milk (80 individual FA) is

219 shown in the Appendix (Table A2).

\subsubsection{Effect of the production system $\times$ month interaction}

221 Significant effects of the production system $\times$ month interaction were identified for milk concentrations of C12:0, C16:0, LA, RA, ALNA (Figure 1), SFA, MUFA, PUFA, n-6, trans FA (total or by excluding VA), n-3/n-6 ratio and AI (Figure 2), $\Delta^{9} \mathrm{I}, \mathrm{C} 14: 1 / \mathrm{C} 14: 0, \mathrm{C} 16: 1 / \mathrm{C} 16: 0$, OA/C18:0 and VA/RA (Appendix, Figure A2). C12:0 concentrations in ORG milk were lower than in CON and FR milk in March, but higher than in FR milk in May; C12:0 concentrations in FR milk were higher than in ORG and CON milk in July and December-February (Figure 1a). C16:0 concentrations were lower in ORG milk than in CON milk in April-November, and compared with FR milk in February; concentrations in FR milk were also lower than in CON milk in May and August-September (Figure 1b).

LA concentrations were higher in ORG milk than in FR milk in April-May and higher in CON milk than in FR milk in December (Figure 1c). ORG milk had higher RA concentrations when compared with FR and CON milk throughout the year, although differences were not statistically significant between ORG and FR milk in August-September and between ORG and CON milk in January-February; FR milk had higher RA concentrations than CON milk in September (Figure 1d). ORG milk had higher ALNA concentrations when compared with FR and CON milk throughout the year; FR milk had higher ALNA concentrations than CON milk in May and August-September (Figure 1e). 
238 SFA concentrations were lower in ORG milk than in FR milk in April, October and February, 239 and when compared with CON milk in April-May; when compared with CON milk, FR milk 240 had less SFA in May but more SFA in February (Figure 2a). FR milk had lower MUFA 241 concentrations than ORG milk in May and CON milk in February, and higher MUFA 242 concentrations than CON milk in June (Figure 2b). ORG milk had higher trans MUFA 243 concentrations than FR and CON milk in April-November but differences in April-May and 244 November were not significant when compared with FR and CON milk, respectively (Figure 2c). ORG milk had higher PUFA concentrations when compared with FR and CON milk throughout the year; CON milk had higher PUFA concentrations than FR milk in November-

247 February (Figure 2d). ORG milk had higher concentrations of cis PUFA than FR milk in April248 July and October-February, and when compared with CON milk in April-May, July, 249 November-December and February; CON milk also contained more cis PUFA than FR milk in 250 November-December and February (Figure 2e). FR milk had lower n-6 concentrations 251 compared with ORG milk in May and with CON milk in November-December and February; 252 CON milk had higher LA concentrations than ORG milk in September (Figure 2f). ORG milk 253 had higher concentrations of trans FA in April-July and October, than CON and FR milk 254 (Figure 2g). When excluding VA from trans FA, ORG milk had higher concentrations than FR 255 milk in April, and when compared with CON milk in July; FR milk contained less trans FA 256 (excluding VA) than CON milk in April, November and December (Figure 2h). ORG milk had 257 higher n-3/n-6 when compared with FR and CON milk in June-February, and when compared 258 with CON milk in April-May; FR milk also had higher n-3/n-6 than CON milk in May (Figure 259 2i). AI was higher in FR milk than in ORG milk in April and February and higher than in CON 260 milk in February; ORG milk had lower AI than CON milk in April (Figure 2j). 
262 When the effect of production system on the estimated FA intakes (according to the National

263 Diet and Nutrition survey (Bates, et al., 2014) and milk FA profiles measured in the present

264 study) was assessed, significant effects were identified for the intakes of PUFA, n-3, ALNA,

265 EPA+DHA, and trans FA across all age groups and genders (Table 3). In male children 4-10

266 years old (yo), estimated intakes from ORG milk fat were higher for PUFA $(+67$ and +85

$267 \mathrm{mg} / \mathrm{d}), \mathrm{n}-3(+51$ and $+41 \mathrm{mg} / \mathrm{d})$, ALNA (+31 and +26 mg/d), EPA+DHA (+3 and +2 mg/d),

268 and trans FA (+57 and $+70 \mathrm{mg} / \mathrm{d}$ ), when compared with CON and FR milk fat, respectively.

269 In male teenagers 11-18 yo, estimated intakes from ORG milk fat were higher for PUFA (+60

270 and $+77 \mathrm{mg} / \mathrm{d}), \mathrm{n}-3(+46$ and $+47 \mathrm{mg} / \mathrm{d})$, ALNA $(+28$ and $+24 \mathrm{mg} / \mathrm{d})$, EPA+DHA $(+2$ and +2

$271 \mathrm{mg} / \mathrm{d})$, and trans FA (+52 and $+63 \mathrm{mg} / \mathrm{d})$, when compared with CON and FR milk fat,

272 respectively. In adult males 19-64 yo, estimated intakes from ORG milk were higher for PUFA

273 (+61 and $+77 \mathrm{mg} / \mathrm{d}), \mathrm{n}-3(+46$ and $+37 \mathrm{mg} / \mathrm{d})$, ALNA $(+28$ and $+24 \mathrm{mg} / \mathrm{d})$, EPA+DHA (+2 and

$274+2 \mathrm{mg} / \mathrm{d})$, and trans FA (+52 and $+64 \mathrm{mg} / \mathrm{d})$, when compared with CON and FR milk fat,

275 respectively. In adult males over 65 yo, estimated intakes from ORG milk were higher for

276 PUFA (+77 and +99 mg/d), n-3 (+58 and +47 mg/d), ALNA (+36 and +30 mg/d), EPA+DHA

277 (+3 and $+3 \mathrm{mg} / \mathrm{d})$, and trans FA (+66 and $+81 \mathrm{mg} / \mathrm{d})$, when compared with CON and FR milk

278 fat, respectively. In female children 4-10 yo, estimated intakes from ORG milk were higher for

PUFA (+63 and +81 mg/d), n-3 (+48 and +39 mg/d), ALNA (+30 and +25 mg/d), EPA+DHA

(+3 and $+2 \mathrm{mg} / \mathrm{d})$, and trans FA (+54 and $+66 \mathrm{mg} / \mathrm{d})$, when compared with CON and FR milk fat, respectively. In female teenagers 11-18 yo, estimated intakes from ORG milk fat were higher for PUFA (+49 and +62 mg/d), n-3 (+37 and +30 mg/d), ALNA (+23 and +19 mg/d), $\mathrm{EPA}+\mathrm{DHA}(+2$ and $+1 \mathrm{mg} / \mathrm{d})$, and trans FA $(+42$ and $+51 \mathrm{mg} / \mathrm{d})$, when compared with CON and FR milk fat, respectively. In adult females 19-64 yo, estimated intakes from ORG milk were higher for PUFA (+42 and $+54 \mathrm{mg} / \mathrm{d}), \mathrm{n}-3(+32$ and $+26 \mathrm{mg} / \mathrm{d})$, ALNA $(+20$ and +17 $\mathrm{mg} / \mathrm{d})$, EPA+DHA (+2 and $+1 \mathrm{mg} / \mathrm{d})$, and trans FA (+36 and $+44 \mathrm{mg} / \mathrm{d})$, when compared with 
287 CON and FR milk, respectively. In adult females over 65 yo, estimated intakes from ORG milk were higher for PUFA (+66 and $+84 \mathrm{mg} / \mathrm{d}), \mathrm{n}-3(+50$ and $+40 \mathrm{mg} / \mathrm{d})$, ALNA $(+30$ and +25 $\mathrm{mg} / \mathrm{d})$, EPA+DHA $(+3$ and $+2 \mathrm{mg} / \mathrm{d})$, and trans FA $(+56$ and $+68 \mathrm{mg} / \mathrm{d})$, when compared with 290 CON and FR milk fat, respectively.

\section{Discussion}

\subsection{Milk basic composition}

293 ORG milk contained more fat than CON milk (as in previous UK retail studies; (Butler, et al., 294 2011b)), and FR milk. This may be an effect of fat standardisation at processing plants rather 295 than an effect of production system, as this is common practice in CON and FR, but not in 296 ORG, supply chain. Although the effect of production system on lactose content was 297 significant, the numerical differences were marginal $(0.4 \mathrm{~g} / \mathrm{kg}$ less in ORG than in CON and FR milk) and potential relevance to consumer health is small. This difference may be due to fat standardisation in CON and FR milk; removing fat from whole milk decreases the dilution

300 factor for remaining milk solids, so could increase milk lactose concentration when expressed as $\mathrm{g} / \mathrm{kg}$ of milk. A significant effect of production system was not observed, for milk protein, casein and SCC contents, in agreement with previous reports for UK milk (Butler, et al., 2011b; Stergiadis, et al., 2012).

\subsection{Milk fatty acid profile}

\subsubsection{Organic milk}

306 The finding that ORG milk contains similar concentrations of SFA to CON milk is consistent with previous UK retail (Butler, et al., 2011b) and farm (Ellis, et al., 2006; Stergiadis, et al., 2012) surveys. In the current study, ORG milk had lower SFA concentrations during the period when cows are turned out to graze (spring) in UK, but also in October and December. However, 
310 the principal SFA in milk fat, C16:0, which is considered undesirable in human nutrition, was

311 found in lowest concentrations in ORG milk, in line with a previous UK retail study (Butler, et

312 al., 2011b). Milk C16:0 originates both from diet and endogenous synthesis by the mammary

313 gland (Chilliard, et al., 2007). Concentration of C16:0 in ORG milk may reflect that lipids in

314 ORG cow diets (rich in fresh grass and with a high forage:concentrate ratio) may contain

315 proportionately less C16:0 than conventional cow diets; and/or cause a potential modification

316 in the amounts of the C16:0 substrates in the rumen, which are used for its de novo synthesis

317 in the mammary gland (Chilliard, et al., 2007). Multivariate analyses in other studies

318 (Stergiadis, et al., 2015a; Stergiadis, et al., 2015b; Stergiadis, et al., 2012) have shown a

319 negative relationship between fresh forage intake (which is expected to be higher in ORG

320 systems), and milk C16:0 concentration. Conversely, other studies reported a higher 16:0

321 concentration (USA; (O'Donnell, Spatny, Vicini, \& Bauman, 2010)) or no difference (the

322 Netherlands; (Capuano, et al., 2015)) between organic and conventional milk. As cow diet is a

323 major driver of milk FA profile (Stergiadis, et al., 2015a; Stergiadis, et al., 2015b; Stergiadis,

324 et al., 2012), these discrepancies probably arise due to variations in diets used in different

325 countries as result of contrasting soil, climate, tradition and legislation (Butler, et al., 2011a).

326 Milk MUFA concentrations, mainly characterised by the nutritionally-desirable OA which

327 represented $73.1 \%$ of total MUFA in the present work, were similar between ORG and CON

328 milk, thus agreeing with previous UK studies (Butler, et al., 2011b; Stergiadis, et al., 2012).

329 The concentrations of OA may be affected by dietary supply, extent of rumen biohydrogenation

$330(\mathrm{RBH})$, but also its synthesis from C18:0 by $\Delta^{9}$-desaturase action in the mammary gland

331 (Destaillats, Trottier, Galvez, \& Angers, 2005). Differences between ORG and CON systems

332 in these factors may have been either small or showing a counteracting effect, thus resulting in

333 similar concentrations of OA in ORG and CON milk. 
334 The finding that ORG milk contains more VA and RA than CON milk is in line with previous retail surveys (Butler, et al., 2011b; Capuano, et al., 2015; O'Donnell, et al., 2010), although other UK farm surveys have shown either no differences (Ellis, et al., 2006) or a significant difference only when ORG was compared with intensive CON production systems during summer (Stergiadis, et al., 2012). VA is an intermediate product of RBH of dietary PUFA, and in particular ALNA (Chilliard, et al., 2007; Destaillats, et al., 2005). Upon absorption and delivery to the mammary gland, part of VA is converted to RA, under the effect of mammary $\Delta^{9}$-desaturase (Chilliard, et al., 2007; Destaillats, et al., 2005). Therefore, cow diets rich in ALNA, such as those of high pasture intake characterizing ORG systems, will increase the availability of substrate for higher VA production in the rumen and the subsequent RA synthesis in the mammary gland (Chilliard, et al., 2007; Elgersma, 2015). Pasture intake is potentially the main driver for milk VA and RA concentrations in the current study because differences in RA concentrations between ORG and CON were not significant during the period that pasture was not available in the UK (December to February).

The higher concentrations of ALNA, EPA and DPA, and consequently the n-3, in ORG than in CON milk is in line with other retail surveys (Butler, et al., 2011b; Capuano, et al., 2015; O'Donnell, et al., 2010). However, for DPA, retail surveys may show only a tendency for higher concentrations in ORG (Butler, et al., 2011b) or inconsistent results between summer and winter (Capuano, et al., 2015). In a previous UK farm survey, ORG milk contained more DPA only when compared with milk from highly-intensive CON production systems (Stergiadis, et al., 2012). The higher concentrations of ALNA in ORG milk were observed throughout the year. In summer, milk ALNA concentrations can be enhanced by (i) higher pasture intake in ORG systems, due to the higher ALNA supply from fresh forage than conserved forage and/or concentrates (Elgersma, 2015), and (ii) clover contribution to the grazing swards, potentially due to the increased transfer rates of dietary ALNA when fresh clover substitutes fresh grass 
in cow diets (Stergiadis, et al., 2018). In winter, grass/clover silage commonly used in ORG systems when pasture is not available, has been found to increase ALNA concentrations when compared with grass or grass/maize silage (Dewhurst, Fisher, Tweed, \& Wilkins, 2003; Wiking, Theil, Nielsen, \& Sorensen, 2010), commonly used in the CON systems. This may be explained by the slower DM degradation (Dewhurst, Evans, Scollan, Moorby, Merry, \& Wilkins, 2003) and rates of RBH of clover compared with grass (Lejonklev, Storm, Larsen, Mortensen, \& Weisbjerg, 2013), which may increase rumen passage rates, reduce RBH of ALNA, and eventually increase transfer rates of dietary ALNA to milk. In humans and animals, including cattle, ALNA is used as substrate for the synthesis of EPA and DPA by various enzymes, including elongases, $\Delta^{5}$-desaturase and $\Delta^{6}$-desaturase (Barcelo-Goblijn, et al., 2009).

Therefore, a higher supply of ALNA in the mammary gland of cows in the ORG systems, as a consequence of the combined effect of high pasture and clover intake, may have increased the substrate available for EPA and DPA synthesis.

372 Factors affecting $\Delta^{9}$-desaturase activity, potentially including, animal genetics, production stage and diet, are not well understood. Transition from winter diets (relying on conserved forages and concentrates) to summer diets (including substantial amounts of pasture) is likely to (i) alter the supply of FA, transferred directly to milk or acting as substrate for conversion to other milk FA, and (ii) exert metabolic changes in the rumen and/or the cow, possibly altering the activity of nutritionally-sensitive enzymes responsible for de novo synthesis of

378 short and medium chain SFA or desaturation of FA in the mammary gland (Lock \& 379 Garnsworthy, 2003). Higher fresh grass intakes, which increase water-soluble carbohydrate 380 intakes and the subsequent insulin levels, may increase $\Delta^{9}$-desaturase activity (Lock, et al., 381 2003), but the opposite was observed in the ORG milk in the current study. ORG dairy herds 382 in the UK extensively use crossbred cows (most typically crosses between Holstein, 383 British/New Zealand Friesian, Jersey and/or Scandinavian Red) while CON herds rely almost 
entirely in Holstein cows. Provided the well documented substantial effect of breed and individual differences on $\Delta^{9}$-desaturase activity, such as the lower activity in Jersey and Holstein $\times$ Jersey crosses than in pure Holstein cows (Palladino, Buckley, Prendiville, Murphy, Callan, \& Kenny, 2010), it is possible that the effect of breed may have overridden any potential effect of diet.

Department of Health and Social Care in the UK has set a maximum reference nutrient intakes (RNI) of SFA and trans FA at $11 \%$ and $2 \%$ of food energy intake, respectively, and recommended intakes of PUFA at $6.5 \%$ of food energy intake (Department of Health, 1991). According to the current average requirements for energy for the different age groups and genders, and an energy content of fat at $37 \mathrm{~kJ} / \mathrm{g}$ (SACN, 2011), under the current dairy fat intakes in the UK (Bates, et al., 2014), milk fat contributes 24-37\% of the maximum recommended intakes of SFA intakes in adults (being maximum for men over 65 yo, which is the group with the maximum milk fat intakes) and $20-43 \%$ of the maximum recommended intakes in children. Overall intakes of SFA will not be affected by switching between milks from different production systems because the effect of production system on milk SFA concentrations was not significant. Even within months that the difference between ORG and CON was maximised and was statistically significant (April; milk SFA concentrations of 680.4 and $705.2 \mathrm{~g} / \mathrm{kg}$ FA respectively), consumption of ORG milk would minimally reduce SFA intake by $0.250 \mathrm{~g} / \mathrm{d}$ in men over 65 yo (contributing $36.5 \% \mathrm{RNI}$ than $37.4 \% \mathrm{RNI}$ ) and 0.214 $\mathrm{g} / \mathrm{d}$ in women (contributing $36.7 \%$ RNI than $37.6 \% \mathrm{RNI}$ ), when compared with CON milk. Previous work has suggested that in order to benefit public health and reduce health care costs, a reduction on milk SFA should be at the level of $150 \mathrm{~g} / \mathrm{kg} \mathrm{FA}$ (Kliem, et al., 2013). According

407 to these, any potential public health impact from the occasional reduction in milk SFA intakes 408 via consumption of ORG milk cannot be claimed by the results of the present work. 
409 Previous work has highlighted that some milk SFA included in the calculations of total milk

410 SFA (e.g. C4:0, C8:0, C10:0), may have beneficial implications to human health (Haug, et al.,

411 2007). Therefore, focusing on SFA which, if excessively consumed, increase CVD risk (C12:0,

412 C14:0 and C16:0; (FAO, 2010)), may be more accurate when discussing milk fat profile.

413 According to the results of this survey and current dairy food consumption in the UK (Bates,

414 et al., 2014), switching from CON to ORG milk fat will reduce consumption of C16:0 by 0.206

$415 \mathrm{~g} / \mathrm{d}$ (from 4.0 to $3.8 \mathrm{~g} / \mathrm{d}$ ) in children 4-10 yo, by $0.164 \mathrm{~g} / \mathrm{d}$ (from 3.2 to $3.0 \mathrm{~g} / \mathrm{d}$ ) in children 11 -

41618 yo, by $181 \mathrm{mg} / \mathrm{d}$ (from 3.5 to $3.3 \mathrm{~g} / \mathrm{d}$ ) in adults $19-64$ yo, and by $243 \mathrm{mg} / \mathrm{d}$ (from 4.7 to 4.5

$417 \mathrm{~g} / \mathrm{d}$ ) in adults over 65 yo. Nutritional recommendations are provided only for total SFA

418 (Department of Health, 1991), so it is not possible to estimate C16:0 contribution from dairy

419 foods.

420 According to the results of the present survey and the current dairy fat intakes in the UK (Bates, et al., 2014), switching from CON to ORG milk fat will increase the contribution of PUFA, expressed as \% RNI, from $4.0 \%$ to $4.6 \%$ in children $4-10$ yo, from $2.1 \%$ to $2.7 \%$ in children 11-18 yo, from $2.4 \%$ to $2.9 \%$ of adults $19-64$ yo, and from $3.6 \%$ to $4.4 \%$ in adults over 65 yo.

The maximum benefit to PUFA intakes from switching from CON to ORG milk was observed 425 in May (milk PUFA concentrations $52.1 \mathrm{~g} / \mathrm{kg}$ FA for ORG and $43.7 \mathrm{~g} / \mathrm{kg}$ FA for CON) when intakes were increased by $131 \mathrm{mg} / \mathrm{d}$ in men over 65 yo (contributing $4.0 \%$ RNI than $4.7 \%$ $\mathrm{RNI}$ ), and $111 \mathrm{mg} / \mathrm{d}$ in women over 65 yo (contributing $4.0 \% \mathrm{RNI}$ than $4.8 \% \mathrm{RNI}$ ). Although the potential health effects by these changes have not been investigated in the current study, these differences are rather small and are unlikely to be associated with reduced chronic disease 430 risk within a whole diet.

431 A switch to ORG milk would increase the intakes of trans FA, expressed as \% RNI, from $10.4 \%$ to $11.8 \%$ in children $4-10$ yo, from $6.0 \%$ to $6.8 \%$ in children $11-18$ yo, from $6.7 \%$ to $7.6 \%$ of adults $19-64$ yo, and from $10.1 \%$ to $11.4 \%$ in adults over 65 yo. However, in this study 
$43 \%$ of trans FA in milk fat was VA, which is associated with positive effects in human health

435 (Field, et al., 2009). If concentrations of VA are not included in the calculation of trans FA,

436

437

438

440

441

442

443

444

445

446

447

448

449

450

451

452

453

454

455

456

457

458

the overall intakes will not be affected by switching between milks from different production systems because the effect of production system on milk trans FA (excluding VA) concentrations was not statistically significant.

The European Food and Safety Authority set the adequate intake (ADI) for ALNA at $0.5 \%$ energy intake (EFSA, 2010). According to the results of the present survey and the current dairy fat intakes in the UK (Bates, et al., 2014), switching from CON to ORG milk fat will increase the intakes of ALNA from 5.8\% to 8.9\% ADI in children 4-10 yo, from $3.0 \%$ to $4.6 \%$ ADI in children $11-18$ yo, from $3.4 \%$ to $5.2 \%$ ADI in adults $19-64$ yo and from $5.2 \%$ to $7.9 \%$ ADI in adults over 65 yo. The maximum potential benefit in intakes of ALNA was observed in September (milk ALNA concentrations $7.8 \mathrm{~g} / \mathrm{kg}$ FA for ORG and $4.7 \mathrm{~g} / \mathrm{kg}$ FA for CON) when intakes could have been increased by $48 \mathrm{mg} / \mathrm{d}$ in males over 65 yo (contributing 9.2\% RNI than 5.6\% ADI), and $40.8 \mathrm{mg} / \mathrm{d}$ in females over 65 yo (contributing 9.3\% ADI than 5.6\% ADI), when compared with CON milk.

The European Food and Safety Authority set the adequate intake (ADI) for EPA+DHA of 250 $\mathrm{mg} / \mathrm{d}$ in adults and children over 24 months old (EFSA, 2010). According to the results of this survey and the current milk intakes in the UK (Bates, et al., 2014), switching from CON to ORG milk fat will increase the intakes of EPA+DHA from $2.7 \%$ ADI to $3.6 \%$ ADI in children 4-10 yo, from $2.1 \%$ ADI to $2.9 \%$ ADI in children $11-18$ yo, from $2.7 \%$ to $3.2 \%$ ADI in adults 19-64 yo, and from $3.2 \%$ to $4.3 \%$ ADI in adults over 65 yo. The maximum potential benefit in intakes of EPA+DHA was observed in June (milk EPA+DHA concentrations $0.84 \mathrm{~g} / \mathrm{kg}$ FA for ORG and $0.78 \mathrm{~g} / \mathrm{kg}$ FA for CON) when intakes could have been increased by $4.0 \mathrm{mg} / \mathrm{d}$ in males over 65 yo (contributing 5.2\% ADI than $3.6 \%$ ADI), and $3.4 \mathrm{mg} / \mathrm{d}$ in females over 65 yo (contributing 4.4\% ADI than 3.1\% ADI), when compared with CON milk. Part of dietary 
459 ALNA in humans is converted to EPA, DPA and DHA, but with conversion efficiencies being 460 lower than $0.2 \%$ (Barcelo-Goblijn, et al., 2009). An additional supply of EPA+DHA may 461 therefore be expected, as a result of milk ALNA metabolism, but the low conversion 462 efficiencies, will result in minimal additional supply of EPA+DHA from ORG than CON milk 463 (less than $1 \mathrm{mg} / \mathrm{d}$ ).

464 According to the results of this survey and the current milk intakes in the UK (Bates, et al., 465 2014), switching from CON to ORG milk fat will increase RA intake by $24.7 \mathrm{mg} / \mathrm{d}$ (from 71.5 to $96.2 \mathrm{mg} / \mathrm{d}$ ) in children $4-10$ yo, by $19.6 \mathrm{mg} / \mathrm{d}$ (from 56.9 to $76.5 \mathrm{mg} / \mathrm{d}$ ) in children $11-18$ yo, by $21.6 \mathrm{mg} / \mathrm{d}$ (from 62.6 to $84.2 \mathrm{mg} / \mathrm{d}$ ) in adults $19-64$ yo, and by $29.1 \mathrm{mg} / \mathrm{d}$ (from 84.2 to $113.3 \mathrm{~g} / \mathrm{d}$ ) in adults over 65 yo. Given that on average $19 \%$ of VA is also endogenously converted to RA in the human body (Field, et al., 2009), consumption of ORG milk may also increase the available RA via endogenous synthesis, because of its higher VA concentrations. RA has been previously associated with a number of health benefits in humans (Dilzer, et al., 2012). However, nutritional recommendations for RA are not currently developed, so it is not possible to estimate RA contribution from dairy foods.

Overall, organic milk could be considered desirable from a human nutrition perspective, in terms of lower SFA and higher PUFA, n-3, ALNA, RA contents, as well as a higher ratio of n3/n-6 and lower TI (which however refer to the whole diet), thus aligning with current nutritional recommendations (EFSA, 2010; FAO, 2010; Givens, 2017). A switch from CON to ORG milk will influence the intakes of these FA, but any implications for human health cannot 479 be drawn in the present study, because these changed intakes are relatively small. The 480 nutritional recommendations (Department of Health, 1991; EFSA, 2010; SACN, 2011) for individual FA or FA groups refer to the total diet rather than a single food, and although the current study estimates the potential changes on FA intakes from dairy products, any potential effect on human health will be influenced by FA intakes from other foods. Current evidence 
suggests there is no positive association between intake of milk and dairy products and the risk of CVD and type-2 diabetes, while consumption of cheese and yoghurt also showed a negative association (Kliem, et al., 2011; Thorning, et al., 2017). This may be an effect of interactions between milk matrix components and enhances the necessity for future research on the effect of milk and dairy products as whole foods, alongside investigations of the nutritional role of their individual components (Kliem, et al., 2011; Thorning, et al., 2017).

\subsubsection{Free-range milk}

The lack of differences between the two conventional systems (CON, FR), one representing typical CON UK dairy management and the other FR practices, is in line with recent results

493 from the Netherlands (Capuano, et al., 2015). Provided that diet, and in particular fresh grass 494 intake, is the major driver for milk FA profiles (Elgersma, 2015; Stergiadis, et al., 2015b; Stergiadis, et al., 2012), the similarities between CON and FR milk may potentially reflect small differences in cow nutrition between the two production systems. Previous studies that showed substantial differences in the FA profile of milk between pasture-based, ORG and CON milk at farm level had investigated low-input pasture-based farms where the average pasture intake was more than 95\% of total cow diet (Butler, et al., 2008; Stergiadis, et al., 2015b).

Provided that FR certification refers to access to outdoors/pasture but without setting minimum requirements for pasture intake, lower contribution of pasture in cow diet when compared with

502 the low-input farms assessed in other studies (Butler, et al., 2008; Stergiadis, et al., 2015b),

503 may potentially explain the lack of effect on milk FA profile. In addition, allowing cows access to pasture for six months is a typical practice in UK CON dairy systems, although maybe at a lesser extent than in FR systems, and this may further contribute to the similarities in cow diets and the subsequent FA profile between $\mathrm{CON}$ and FR milk. Other potential reasons for this

507 observations that have been provided in the Netherlands was (i) that not all farms provide 508 access to pasture the same time, thus diluting the effect of pasture intake when bulking milk at 
the dairy, and (ii) the contribution of fresh-cut grass in indoor CON systems, which would reduce the differences between grazing and indoor cows (Capuano, et al., 2015).

511 Despite the overall similarities between FR and CON milk, significant differences were

512 observed in specific months within the grazing season, potentially as an effect of the higher

513 pasture intake in FR herds than in CON herds during these months. For example, FR milk had

514 a more preferable FA profile than CON milk in May, August and/or September, by containing 515 less of the nutritionally-undesirable C16:0, more of the nutritionally-desirable ALNA and RA and by having a higher n-3/n-6 ratio; thus representing a favourable effect of substituting SFA with MUFA and PUFA, in line with current recommendations (EFSA, 2010; FAO, 2010; Givens, 2017). FR milk also contained less SFA and more MUFA in May, but this relationship was reversed in February. The lower PUFA in FR than CON milk during the indoor period mainly reflects the lower concentrations of n-6 and LA, which may be a result of lower use of maize silage, a main driver for milk n-6 concentrations (Chilliard, et al., 2007; Stergiadis, et al., 2015b), in FR than in CON herds. Inconsistency in the differences between FR and CON milk throughout the year may have also been a consequence of the small number of farms contributing the FR milk at the dairies. Because of that, the effect of cow diet in individual FR farms has a proportionately higher impact to the final product.

\subsubsection{Seasonal variation}

527

The effect of season on the FA profile of UK retail milk has been extensively investigated in other surveys (Butler, et al., 2011b; Kliem, et al., 2013). In agreement with the present work, these previous studies highlighted that concentrations of milk total SFA and individual SFA (C12:0, C14:0, C16:0) are lower, and those of VA, OA, RA, ALNA, EPA, n-3, PUFA, EPA are higher, during the grazing season. In the UK, in dairy systems where cows have access to pasture, and in line with local climate, animals are housed in winter (December-February), turn out to pasture at March-April, have a period where grazing is maximised (May-September) and 
then gradually return to indoor diets rich in conserved forages and concentrates late in autumn

535 (October-November). Fresh grass is rich in PUFA, including ALNA, and therefore its 536 potentially higher dietary intakes may result in (i) higher milk ALNA concentrations, via direct 537 transfer to milk (Elgersma, 2015), (ii) higher OA, via rumen synthesis of C18:0 (end product 538 of RBH of FA) and the subsequent increased C18:0 supply in the mammary gland for OA 539 synthesis (Destaillats, et al., 2005), (iii) higher milk VA and RA concentrations, via rumen synthesis of VA and the subsequent increase in VA supply in the mammary gland for RA synthesis (Chilliard, et al., 2007; Destaillats, et al., 2005), (iv) higher EPA and DPA, potentially via the higher supply of their substrate ALNA (Barcelo-Goblijn, et al., 2009), and eventually (v) lower total SFA and individual SFA (C12:0, C14:0, C16:0) concentrations. Given that 60\% of the samples in the present study were from ORG and FR farms, which are expected to provide access to pasture during the grazing season, the effect of pasture intake appears to be the most possible explanation of the seasonal variation. The fact that pasture intake is among the strongest drivers of milk FA profiles in the UK, has been previously demonstrated in multivariate redundancy analyses in data collected from dairy farms (Stergiadis, et al., 2015b;

549 Stergiadis, et al., 2012).

\section{Conclusions}

551 Organic retail milk showed a more favourable FA profile, containing more nutritionally552 desirable FA, less C16:0, and a higher n-3/n-6 ratio than conventional milk. During specific 553 months, organic milk also had less total SFA. The free-range milk had similar FA profile to conventional milk, but contained less SFA (including C16:0) and more ALNA and RA, in specific months within the outdoor/grazing season. Although background information on dairy management practices was not available, it is highly likely that differences in milk FA profiles

557 resulted from contrasting cow diets, and in particular the intakes of pasture, clover and 558 forage:concentrate ratio. Based on measured milk FA profiles across the production systems, 
559 dairy fat contributes approximately one-third of the maximum recommended intake of SFA in

560 adult consumer diets. Consuming organic dairy products would increase intakes of

561 nutritionally-desirable PUFA, and reduce consumption of nutritionally-undesirable SFA.

562 However, when compared with conventional milk in terms of daily recommended intakes of

563 these FA, there would be relatively little difference. Therefore, any implications to human

564 health cannot be drawn from the present study.

\section{Acknowledgements}

566 The authors gratefully acknowledge financial support from the University of Reading. CBB

567 was in receipt of a Science Without Borders scholarship from the Brazilian Federal

568 Government. The work of SG in the project was funded by the Undergraduate Research

569 Opportunities Programme of the University of Reading. Authors would also like to

570 acknowledge the help of dairies working in collaboration with the Free Range Dairy Network

571 with the collection and postage of free-range retail milk samples. 
573 Barcelo-Goblijn, G., \& Murphy, E. J. (2009). Alpha-linolenic acid and its conversion to longer chain n-3 fatty acids: benefits for human health and a role in maintaining tissue n-3 fatty acid levels. Progress in Lipid Research, 48, 355-374.

Bates, B., Lennox, A., Prentice, A., Bates, C., Page, P., Nicholson, S., \& Swan, G. (2014). National Diet and Nutrition Survey. Results from Years 1-4 (combined) of the rolling https://www.gov.uk/government/statistics/national-diet-and-nutrition-survey-resultsfrom-years-1-to-4-combined-of-the-rolling-programme-for-2008-and-2009-to-2011and-2012 (Ed.), (pp. 139): Public Health England.

Butler, G., Nielsen, J. H., Larsen, M. K., Rehberger, B., Stergiadis, S., Canever, A., \& Leifert, C. (2011a). The effects of dairy management and processing on quality characteristics of milk and dairy products. NJAS Wageningen Journal of Life Science, 58, 97-102.

Butler, G., Nielsen, J. H., Slots, T., Seal, C. J., Eyre, M. D., Sanderson, R., \& Leifert, C. (2008). Fatty acid and fat-soluble antioxidant concentrations in milk from high- and low-input conventional and organic systems: seasonal variation. Journal of Science of Food and Agriculture, 88, 1431-1441.

Butler, G., Stergiadis, S., Seal, C. J., Eyre, M. D., \& Leifert, C. (2011b). Fat composition of organic and conventional retail milk in northeast England. Journal of Dairy Science, 94, 24-36.

Capuano, E., Gravink, R., Boerrigter-Eenling, R., \& van Ruth, S. M. (2015). Fatty acid and triglycerides profiling of retail organic, conventional and pasture milk: Implications for health and authenticity. International Dairy Journal, 42, 58-63. 
595 Chilliard, Y., Glasser, F., Ferlay, A., Bernard, L., Rouel, J., \& Doreau, M. (2007). Diet, rumen biohydrogenation and nutritional quality of cow and goat milk fat. European Journal of Lipid Science and Technology, 109, 828-855.

598 Chilliard, Y., Martin, C., Rouel, J., \& Doreau, M. (2009). Milk fatty acids in dairy cows fed whole crude linseed, extruded linseed, or linseed oil, and their relationship with methane output. Journal of Dairy Science, 92, 5199-5211.

Department of Health. (1991). Dietary reference values for food energy and nutrients for the United Kingdom. London, UK: H.M. Stationery Office.

Destaillats, F., Trottier, J. P., Galvez, J. M. G., \& Angers, P. (2005). Analysis of $\alpha$-linolenic acid biohydrogenation intermediates in milk fat with emphasis on conjugated linolenic acids. Journal of Dairy Science, 88, 3231-3239.

607

Dewhurst, R. J., Evans, R. T., Scollan, N. D., Moorby, J. M., Merry, R. J., \& Wilkins, R. J. (2003). Comparison of grass and legume silages for milk production. 2. In vivo and in sacco evaluations of rumen function. Journal of Dairy Science, 86(8), 2612-2621.

Dewhurst, R. J., Fisher, W. J., Tweed, J. K. S., \& Wilkins, R. J. (2003). Comparison of grass and legume silages for milk production. 1. Production responses with different levels of concentrate. Journal of Dairy Science, 86(8), 2598-2611.

Dilzer, A., \& Park, Y. (2012). Implication of Conjugated Linoleic Acid (CLA) in Human Health. Critical Reviews in Food Science and Nutrition, 52(6), 488-513.

614 EFSA. (2010). Scientific Opinion on Dietary Reference Values for fats, including saturated fatty acids, polyunsaturated fatty acids, monounsaturated fatty acids, trans fatty acids, and cholesterol. EFSA Journal, 8, 1461.

617 Elgersma, A. (2015). Grazing increases the unsaturated fatty acid concentration of milk from grass-fed cows: A review of the contributing factors, challenges and future perspectives. European Journal of Lipid Science and Technology, 117, 1345-1369. 
Ellis, K. A., Innocent, G., Grove-White, D., Cripps, P., McLean, W. G., Howard, C. V., \& Mihm, M. (2006). Comparing the fatty acid composition of organic and conventional milk. Journal of Dairy Science, 89, 1938-1950.

FAO. (2010). Fats and fatty acids in human nutrition - Report of an expert consultation. Rome, Italy: Food and Agriculture Organization of the United Nations.

Field, C. J., Blewett, H. H., Proctor, S., \& Vine, D. (2009). Human health benefits of vaccenic acid. Applied Physiology, Nutrition, and Metabolism, 34, 979-991.

Gilmour, A. R., Thompson, R., \& Cullis, B. R. (1995). Average information REML: an efficient algorithm for variance parameter estimation in linear-mixed models. Biometrics, 51, 1440-1450.

Givens, D. I. (2017). Saturated fats, dairy foods and health: A curious paradox? Nutrition Bulletin, 42, 274-282.

Haug, A., Hostmark, A. T., \& Harstad, O. M. (2007). Bovine milk in human nutrition. Lipids in Health and Disease, 6, 25.

Kay, J. K., Mackle, T. R., Auldist, M. J., Thomson, N. A., \& Bauman, D. E. (2004). Endogenous synthesis of cis-9, trans-11 conjugated linoleic acid in dairy cows fed fresh pasture. Journal of Dairy Science, 87, 369-378.

Kliem, K. E., \& Givens, D. I. (2011). Dairy products in the food production chain: their impact on health. Annual Review of Food Science and Technology, 2, 21-36.

Kliem, K. E., \& Shingfield, K. J. (2016). Manipulation of milk fatty acid composition in lactating cows: Opportunities and challenges. European Journal of Lipid Science and Technology, 118, 1661-1683.

Kliem, K. E., Shingfield, K. J., Livingstone, K. M., \& Givens, D. I. (2013). Seasonal variation in the fatty acid composition of milk available at retail in the United Kingdom and implications for dietary intake. Food Chemistry, 141, 274-281. 
645 Lejonklev, J., Storm, A. C., Larsen, M. K., Mortensen, G., \& Weisbjerg, M. R. (2013). Differences in rate of ruminal hydrogenation of $\mathrm{C} 18$ fatty acids in clover and ryegrass. Animal, 7(10), 1607-1613.

Lock, A., \& Garnsworthy, P. (2003). Seasonal variation in milk conjugated linoleic acid and $\Delta^{9}$-desaturase activity in dairy cows. Livestock Production Science, 79, 47-59.

O'Donnell, A. M., Spatny, K. P., Vicini, J. L., \& Bauman, D. E. (2010). Survey of the fatty 651 acid composition of retail milk differing in label claims based on production management practices. J Dairy Sci, 93, 1918-1925.

Palladino, R. A., Buckley, F., Prendiville, R., Murphy, J. J., Callan, J., \& Kenny, D. A. (2010). A comparison between Holstein-Friesian and Jersey dairy cows and their F1 hybrid on milk fatty acid composition under grazing conditions. Journal of Dairy Science, 93, 2176-2184.

658

Pereira, P. C. (2014). Milk nutritional composition and its role in human health. Nutrition, 30, 619-627.

SACN. (2011). Dietary reference values for energy. In Scientific Advisory Committee in 660 Nutrition (Ed.)). London, UK: Crown Copyright.

Srednicka-Tober, D., Baranski, M., Seal, C., Sanderson, R., Benbrook, C., Steinshamn, H., 662 Gromadzka-Ostrowska, J., Rembialkowska, E., Skwarlo-Sonta, K., Eyre, M., Cozzi, G., Larsen, M. K., Jordon, T., Niggli, U., Sakowski, T., Calder, P. C., Burdge, G. C., Sotiraki, S., Stefanakis, A., Yolcu, H., Stergiadis, S., Chatzidimitriou, E., Butler, G., Stewart, G., \& Leifert, C. (2016). Composition differences between organic and 668 Stergiadis, S., Bieber, A., Franceschin, E., Isensee, A., Eyre, M. D., Maurer, V., 669 Chatzidimitriou, E., Cozzi, G., Bapst, B., Stewart, G., Gordon, A., \& Butler, G. (2015a). 
Impact of Brown Swiss genetics on milk quality from low-input herds in Switzerland: interactions with grazing intake and pasture type. Food Chemistry, 175, 609-618.

Stergiadis, S., Hynes, D. N., Thomson, A. L., Kliem, K. E., Berlitz, C. G. B., Gunal, M., \& Yan, T. (2018). Effect of substituting fresh-cut perennial ryegrass with fresh-cut white clover on bovine milk fatty acid profile. Journal of the Science of Food and Agriculture, under review.

Stergiadis, S., Leifert, C., Seal, C. J., Eyre, M. D., Larsen, M. K., Slots, T., Nielsen, J. H., \& Butler, G. (2015b). A 2-year study on milk quality from three pasture-based dairy systems of contrasting production intensities in Wales. Journal of Agricultural Science, 153(4), 708-731.

Stergiadis, S., Leifert, C., Seal, C. J., Eyre, M. D., Nielsen, J. H., Larsen, M. K., Slots, T., Steinshamn, H., \& Butler, G. (2012). Effect of feeding intensity and milking system on nutritionally relevant milk components in dairy farming systems in the north east of England. Journal of Agricultural and Food Chemistry, 60, 7270-7281.

Swanson, D., Block, R., \& Mousa, S. (2012). Omega-3 fatty acids EPA and DHA: health benefits throughout life. Advances in Nutrition, 3, 1-7.

Thorning, T. K., Bertram, H. C., Bonjour, J.-P., de Groot, L., Dupont, D., Feeney, E., Ipsen, R., Lecerf, J. M., Mackie, A., McKinley, M. C., Michalski, M.-C., Rémond, D., Risérus, U., Soedamah-Muthu, S. S., Tholstrup, T., Weaver, C., Astrup, A., \& Givens, I. (2017). Whole dairy matrix or single nutrients in assessment of health effects: current evidence and knowledge gaps. The American Journal of Clinical Nutrition, 105(5), 1033-1045.

Ulberth, F., Gabernig, R. G., \& Schrammel, F. (1999). Flame-ionization detector response to methyl, ethyl, propyl and butyl esters of fatty acids. Journal of the American Oil Chemists Society, 76, 263-266. 
694 Wiking, L., Theil, P. K., Nielsen, J. H., \& Sorensen, M. T. (2010). Effect of grazing fresh 695 legumes or feeding silage on fatty acids and enzymes involved in the synthesis of milk fat in dairy cows. Journal of Dairy Research, 77(3), 337-342. 
Table 1

Means (and average SE) and ANOVA P-values for the effect of production system (conventional, CON; organic, ORG; free-range, FR) on the basic composition and fatty acid (FA) profile ( $\mathrm{g} / \mathrm{kg}$ total FA) of milk collected from retail outlets during the year

\begin{tabular}{|c|c|c|c|c|c|}
\hline \multirow[b]{2}{*}{ Parameters assessed } & \multicolumn{3}{|c|}{ Production System } & \multirow[b]{2}{*}{ SE } & \multirow[b]{2}{*}{$\begin{array}{l}\text { ANOVA } \\
\text { P-values }{ }^{b}\end{array}$} \\
\hline & $\begin{array}{l}\mathrm{CON} \\
\mathrm{n}=48\end{array}$ & $\begin{array}{l}\text { ORG } \\
\mathrm{n}=48\end{array}$ & $\begin{array}{c}\mathrm{FR} \\
\mathrm{n}=24^{a}\end{array}$ & & \\
\hline \multicolumn{6}{|l|}{ Basic composition } \\
\hline Fat (g/kg milk) & $34.9^{\mathrm{B}}$ & $40.0^{\mathrm{A}}$ & $37.0^{\mathrm{B}}$ & 0.60 & $* * *$ \\
\hline Protein (g/kg milk) & 32.7 & 32.4 & 32.7 & 0.49 & ns \\
\hline Casein (g/kg milk) & 25.5 & 25.2 & 25.4 & 0.41 & ns \\
\hline Lactose ( $\mathrm{g} / \mathrm{kg}$ milk) & $45.2^{\mathrm{A}}$ & $44.8^{\mathrm{B}}$ & $45.2^{\mathrm{A}}$ & 0.10 & $*$ \\
\hline $\mathrm{SCC}^{c}\left(\mathrm{x} 10^{3} / \mathrm{ml} \mathrm{milk}\right)$ & 38 & 137 & 58 & 30 & ns \\
\hline \multicolumn{6}{|l|}{ Individual FA } \\
\hline \multicolumn{6}{|l|}{$\mathbf{S F A}^{d}$} \\
\hline C12:0 & 33.4 & 32.4 & 34.8 & 0.67 & ns \\
\hline C14:0 & 111 & 114 & 114 & 1.2 & ns \\
\hline C16:0 & $331^{\mathrm{A}}$ & $314^{\mathrm{B}}$ & $325^{\mathrm{A}}$ & 2.0 & $* * *$ \\
\hline C18:0 & 99.5 & 106.1 & 103.3 & 2.36 & ns \\
\hline \multicolumn{6}{|l|}{ MUFA $^{e}$} \\
\hline VA & $12.2^{\mathrm{B}}$ & $17.1^{\mathrm{A}}$ & $12.3^{\mathrm{B}}$ & 0.68 & $* *$ \\
\hline $\mathrm{OA}$ & 200 & 197 & 199 & 2.6 & ns \\
\hline \multicolumn{6}{|l|}{ PUFA $^{f}$} \\
\hline LA & 17.1 & 16.6 & 15.3 & 0.75 & ns \\
\hline RA & $5.91^{\mathrm{B}}$ & $7.95^{\mathrm{A}}$ & $6.06^{\mathrm{B}}$ & 0.259 & $* * *$ \\
\hline ALNA & $4.39^{\mathrm{B}}$ & $6.71^{\mathrm{A}}$ & $4.76^{\mathrm{B}}$ & 0.124 & $* * *$ \\
\hline EPA & $0.484^{\mathrm{B}}$ & $0.674^{\mathrm{A}}$ & $0.551^{\mathrm{B}}$ & 0.0226 & $* * *$ \\
\hline DPA & $0.795^{\mathrm{B}}$ & $1.024^{\mathrm{A}}$ & $0.834^{\mathrm{B}}$ & 0.0279 & $* * *$ \\
\hline DHA & 0.067 & 0.078 & 0.060 & 0.0100 & ns \\
\hline \multicolumn{6}{|l|}{ FA groups } \\
\hline SFA & 688 & 684 & 692 & 2.6 & ns \\
\hline MUFA & 273 & 272 & 270 & 2.4 & ns \\
\hline cis MUFA $^{g}$ & 242 & 237 & 240 & 2.9 & ns \\
\hline trans MUFA $^{h}$ & $31.0^{\mathrm{B}}$ & $35.0^{\mathrm{A}}$ & $30.0^{\mathrm{B}}$ & 0.84 & $* * *$ \\
\hline PUFA & $39.7^{\mathrm{B}}$ & $44.7^{\mathrm{A}}$ & $38.3^{\mathrm{B}}$ & 0.42 & $* * *$ \\
\hline cis PUFA ${ }^{i}$ & $25.9^{\mathrm{B}}$ & $28.0^{\mathrm{A}}$ & $24.4^{\mathrm{B}}$ & 0.31 & $*$ \\
\hline trans $\mathrm{PUFA}^{j}$ & $0.34^{\mathrm{B}}$ & $0.52^{\mathrm{A}}$ & $0.37^{\mathrm{B}}$ & 0.033 & $*$ \\
\hline cis/trans + trans $/$ cis PUFA $^{k}$ & $13.4^{\mathrm{B}}$ & $16.1^{\mathrm{A}}$ & $13.5^{\mathrm{B}}$ & 0.49 & $* *$ \\
\hline$n-3^{l}$ & $7.93^{\mathrm{B}}$ & $11.69^{\mathrm{A}}$ & $8.66^{\mathrm{B}}$ & 0.332 & $* * *$ \\
\hline$n-6^{m}$ & 20.9 & 20.0 & 18.9 & 0.81 & ns \\
\hline$n-3 / n-6$ & $0.39^{\mathrm{B}}$ & $0.59^{\mathrm{A}}$ & $0.46^{\mathrm{B}}$ & 0.031 & $* *$ \\
\hline trans $\mathrm{FA}^{n}$ & $3.13^{\mathrm{B}}$ & $3.55^{\mathrm{A}}$ & $3.03^{\mathrm{B}}$ & 0.086 & $* *$ \\
\hline trans FA (exc. VA) & 1.90 & 1.84 & 1.81 & 0.043 & ns \\
\hline \multicolumn{6}{|l|}{ Indices } \\
\hline \multicolumn{6}{|l|}{ Human health-related } \\
\hline $\mathrm{AI}^{o}$ & 2.60 & 2.56 & 2.69 & 0.047 & ns \\
\hline $\mathrm{TI}^{p}$ & $3.13^{\mathrm{A}}$ & $2.89^{\mathrm{B}}$ & $3.15^{\mathrm{A}}$ & 0.027 & $* * *$ \\
\hline \multicolumn{6}{|l|}{$\Delta^{9}$-desaturase activity } \\
\hline$\Delta^{9} \mathrm{I}^{r}$ & 0.297 & 0.296 & 0.296 & 0.0026 & ns \\
\hline $\mathrm{C} 14: 1 / \mathrm{C} 14: 0$ & $0.084^{\mathrm{A}}$ & $0.080^{\mathrm{B}}$ & $0.084^{\mathrm{A}}$ & 0.0007 & $* *$ \\
\hline $\mathrm{C} 16: 1 / \mathrm{C} 16: 0$ & $0.058^{\mathrm{A}}$ & $0.056^{\mathrm{B}}$ & $0.058^{\mathrm{A}}$ & 0.0006 & $*$ \\
\hline OA/C18:0 & $2.011^{\mathrm{A}}$ & $1.856^{\mathrm{B}}$ & $1.928^{\mathrm{A}}$ & 0.0371 & $*$ \\
\hline RA/VA & 0.491 & 0.469 & 0.501 & 0.0085 & $\dagger$ \\
\hline \multicolumn{6}{|c|}{$\begin{array}{l}{ }^{a} \text { In September, there was a missing sample of free-range milk in the analysis of basic } \\
\text { composition and the mean on this set of parameters was calculated from } 23 \text { samples } \\
{ }^{b} \text { Significances were declared at } * * *, P<0.001 ; * *, P<0.01 ; *, P<0.05 ;+, 0.05<\mathrm{P}<0.10 \\
\text { (trend); ns, } \mathrm{P}>0.10 \text { (non-significant). Means for production system within a row with } \\
\text { different upper case letters are significantly different according to Fisher's Least Significant }\end{array}$} \\
\hline
\end{tabular}




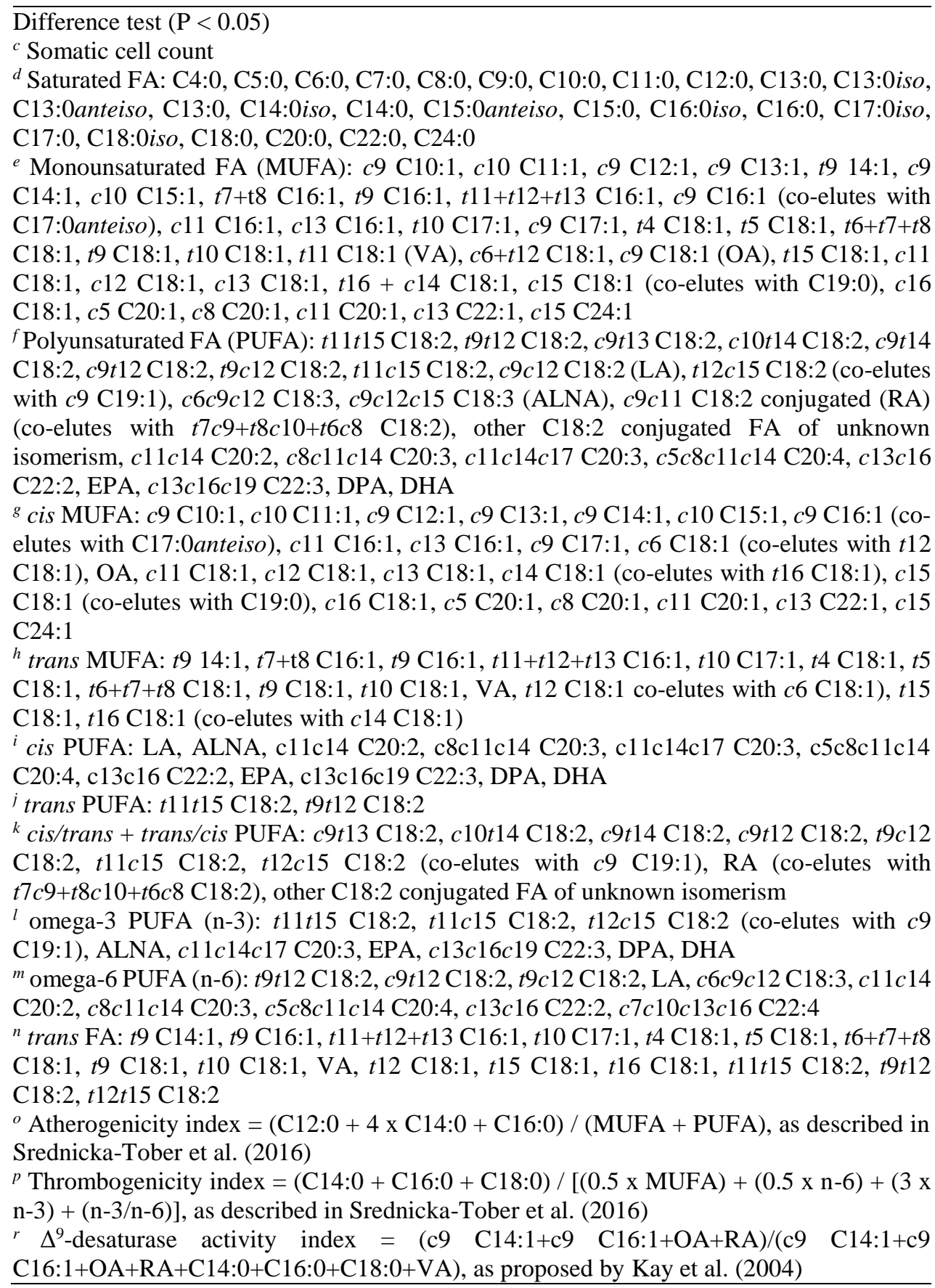


Table 2

Means (and average SE) and ANOVA P-values for the effect of month on the basic composition and fatty acid (FA) profile (g/kg total FA) of milk collected from retail outlets during the year

\begin{tabular}{|c|c|c|c|c|c|c|c|c|c|c|c|c|c|c|}
\hline \multirow[b]{2}{*}{ Parameters assessed } & \multicolumn{12}{|c|}{ Month } & \multirow[b]{2}{*}{ SE } & \multirow[b]{2}{*}{$\begin{array}{l}\text { ANOVA } \\
\text { P-values }\end{array}$} \\
\hline & $\begin{array}{c}\text { March } \\
n=10\end{array}$ & $\begin{array}{l}\text { April } \\
\mathrm{n}=10\end{array}$ & $\begin{array}{l}\text { May } \\
\mathrm{n}=10\end{array}$ & $\begin{array}{l}\text { June } \\
\mathrm{n}=10\end{array}$ & $\begin{array}{c}\text { July } \\
\mathrm{n}=10\end{array}$ & $\begin{array}{c}\text { August } \\
n=10\end{array}$ & $\begin{array}{c}\text { September } \\
\mathrm{n}=10^{a}\end{array}$ & $\begin{array}{c}\text { October } \\
n=10\end{array}$ & $\begin{array}{c}\text { November } \\
n=10\end{array}$ & $\begin{array}{c}\text { December } \\
n=10\end{array}$ & $\begin{array}{c}\text { January } \\
n=10\end{array}$ & $\begin{array}{c}\text { February } \\
n=10\end{array}$ & & \\
\hline \multicolumn{15}{|l|}{ Basic composition } \\
\hline Fat ( $\mathrm{g} / \mathrm{kg}$ milk) & $38.0^{\mathrm{AB}}$ & $38.0^{\mathrm{AB}}$ & $36.8^{\mathrm{D}}$ & $36.9^{\mathrm{CD}}$ & $36.6^{\mathrm{D}}$ & $36.9^{\mathrm{D}}$ & $37.2^{\mathrm{CD}}$ & $37.2^{\mathrm{BCD}}$ & $38.5^{\mathrm{A}}$ & $36.9^{\mathrm{D}}$ & $37.7^{\mathrm{ABC}}$ & $37.7^{\mathrm{ABC}}$ & 0.49 & $* * *$ \\
\hline Protein ( $\mathrm{g} / \mathrm{kg}$ milk) & $32.8^{\mathrm{BCE}}$ & $32.4^{\mathrm{CDEF}}$ & $33.2^{\mathrm{B}}$ & $32.2^{\mathrm{DEF}}$ & $31.8^{\mathrm{F}}$ & $32.1^{\mathrm{CDEF}}$ & $32.4^{\mathrm{EF}}$ & $33.2^{\mathrm{B}}$ & $34.0^{\mathrm{A}}$ & $32.1^{\mathrm{DEF}}$ & $32.5^{\mathrm{CDEF}}$ & $32.1^{\mathrm{F}}$ & 0.36 & $* * *$ \\
\hline Casein (g/kg milk) & $25.2^{\mathrm{CD}}$ & $25.0^{\mathrm{D}}$ & $25.7^{\mathrm{BC}}$ & $24.8^{\mathrm{D}}$ & $24.9^{\mathrm{D}}$ & $25.3^{\mathrm{CD}}$ & $25.3^{\mathrm{CD}}$ & $26.0^{\mathrm{AB}}$ & $26.6^{\mathrm{A}}$ & $24.8^{\mathrm{D}}$ & $25.3^{\mathrm{CD}}$ & $25.0^{\mathrm{D}}$ & 0.32 & $* * *$ \\
\hline Lactose (g/kg milk) & $45.5^{\mathrm{ABC}}$ & $45.6^{\mathrm{A}}$ & $45.7^{\mathrm{AB}}$ & $45.2^{\mathrm{BCD}}$ & $44.4^{\mathrm{EF}}$ & $44.9^{\mathrm{DE}}$ & $44.2^{\mathrm{F}}$ & $44.3^{\mathrm{F}}$ & $45.4^{\mathrm{ABCD}}$ & $44.5^{\mathrm{EF}}$ & $45.2^{\mathrm{CD}}$ & $45.4^{\mathrm{ABCD}}$ & 0.19 & $* * *$ \\
\hline $\operatorname{SCC}^{c}\left(\times 10^{3}\right)$ & $52^{\mathrm{C}}$ & $48^{\mathrm{C}}$ & $49^{\mathrm{C}}$ & $30^{\mathrm{C}}$ & $40^{\mathrm{C}}$ & $38^{\mathrm{C}}$ & $44^{\mathrm{C}}$ & $38^{\mathrm{C}}$ & $35^{\mathrm{C}}$ & $219^{\mathrm{AB}}$ & $117^{\mathrm{BC}}$ & $270^{\mathrm{A}}$ & 48 & $* * *$ \\
\hline \multicolumn{15}{|l|}{ Individual FA } \\
\hline \multicolumn{15}{|l|}{ SFA ${ }^{d}$} \\
\hline C12:0 & $35.9^{\mathrm{B}}$ & $34.8^{\mathrm{BCD}}$ & $34.2^{\mathrm{D}}$ & $31.1^{\mathrm{EF}}$ & $31.4^{\mathrm{E}}$ & $31.1^{\mathrm{EF}}$ & $27.5^{\mathrm{G}}$ & $29.9^{F}$ & $37.7^{\mathrm{A}}$ & $35.7^{\mathrm{BC}}$ & $35.6^{\mathrm{BC}}$ & $34.3^{\mathrm{CD}}$ & 0.61 & $* * *$ \\
\hline $\mathrm{C} 14: 0$ & $116^{\mathrm{B}}$ & $113^{\mathrm{C}}$ & $109^{\mathrm{DE}}$ & $107^{\mathrm{E}}$ & $109^{\mathrm{D}}$ & $109^{\mathrm{DE}}$ & $105^{\mathrm{F}}$ & $110^{\mathrm{D}}$ & $123^{\mathrm{A}}$ & $117^{\mathrm{B}}$ & $117^{\mathrm{B}}$ & $116^{\mathrm{B}}$ & 1.1 & $* * *$ \\
\hline C16:0 & $341^{\mathrm{A}}$ & $321^{\mathrm{C}}$ & $289^{\mathrm{E}}$ & $297^{\mathrm{D}}$ & $299^{\mathrm{D}}$ & $305^{\mathrm{D}}$ & $319^{C}$ & $329^{\mathrm{B}}$ & $346^{\mathrm{A}}$ & $348^{\mathrm{A}}$ & $344^{\mathrm{A}}$ & $342^{\mathrm{A}}$ & 2.7 & $* * *$ \\
\hline C18:0 & $97.2^{\mathrm{D}}$ & $104.0^{\mathrm{C}}$ & $108.1^{\mathrm{B}}$ & $110.1^{\mathrm{AB}}$ & $108.7^{\mathrm{B}}$ & $107.7^{\mathrm{B}}$ & $111.3^{\mathrm{A}}$ & $104.1^{\mathrm{C}}$ & $90.4^{\mathrm{E}}$ & $96.6^{\mathrm{D}}$ & $97.3^{\mathrm{D}}$ & $99.3^{\mathrm{D}}$ & 1.80 & $* * *$ \\
\hline \multicolumn{15}{|l|}{ MUFA $^{e}$} \\
\hline VA & $10.1^{\mathrm{E}}$ & $12.2^{\mathrm{D}}$ & $20.9^{\mathrm{A}}$ & $15.9^{\mathrm{C}}$ & $16.1^{\mathrm{C}}$ & $17.2^{\mathrm{BC}}$ & $18.6^{\mathrm{B}}$ & $17.7^{\mathrm{BC}}$ & $10.9^{\mathrm{DE}}$ & $9.9^{\mathrm{E}}$ & $10.2^{\mathrm{E}}$ & $10.5^{\mathrm{DE}}$ & 0.72 & $* * *$ \\
\hline OA & $186^{\mathrm{D}}$ & $195^{\mathrm{C}}$ & $209^{\mathrm{B}}$ & $212^{\mathrm{B}}$ & $211^{\mathrm{B}}$ & $211^{\mathrm{B}}$ & $223^{\mathrm{A}}$ & $213^{\mathrm{B}}$ & $183^{\mathrm{DE}}$ & $178^{\mathrm{E}}$ & $179^{\mathrm{E}}$ & $184^{\mathrm{DE}}$ & 2.5 & $* * *$ \\
\hline \multicolumn{15}{|l|}{ PUFA $^{f}$} \\
\hline LA & $17.4^{\mathrm{AB}}$ & $18.1^{\mathrm{A}}$ & $17.2^{\mathrm{ABC}}$ & $16.8^{\mathrm{BCD}}$ & $15.5^{\mathrm{EF}}$ & $16.4^{\mathrm{CDE}}$ & $16.9^{\mathrm{CD}}$ & $17.2^{\mathrm{ABC}}$ & $15.7^{\mathrm{EF}}$ & $15.6^{\mathrm{F}}$ & $15.5^{\mathrm{F}}$ & $16.1^{\mathrm{DEF}}$ & 0.55 & $* * *$ \\
\hline ALNA & $4.76^{\mathrm{E}}$ & $5.65^{\mathrm{C}}$ & $8.83^{\mathrm{A}}$ & $8.31^{\mathrm{AB}}$ & $8.52^{\mathrm{AB}}$ & $8.44^{\mathrm{AB}}$ & $8.36^{\mathrm{AB}}$ & $7.97^{\mathrm{B}}$ & $5.62^{\mathrm{CD}}$ & $4.76^{\mathrm{E}}$ & $4.92^{\mathrm{DE}}$ & $4.93^{\mathrm{DE}}$ & 0.286 & $* * *$ \\
\hline RA & $4.69^{\mathrm{D}}$ & $5.20^{\mathrm{C}}$ & $6.54^{\mathrm{A}}$ & $6.09^{\mathrm{B}}$ & $6.07^{\mathrm{B}}$ & $5.99^{\mathrm{B}}$ & $6.11^{\mathrm{B}}$ & $5.51^{\mathrm{C}}$ & $4.60^{\mathrm{D}}$ & $4.52^{\mathrm{D}}$ & $4.63^{\mathrm{D}}$ & $4.72^{\mathrm{D}}$ & 0.127 & $* * *$ \\
\hline EPA & $0.502^{\mathrm{CD}}$ & $0.513^{\mathrm{CD}}$ & $0.636^{\mathrm{A}}$ & $0.641^{\mathrm{AB}}$ & $0.659^{\mathrm{A}}$ & $0.644^{\mathrm{AB}}$ & $0.647^{\mathrm{A}}$ & $0.611^{\mathrm{B}}$ & $0.535^{\mathrm{C}}$ & $0.515^{\mathrm{CD}}$ & $0.488^{\mathrm{D}}$ & $0.484^{\mathrm{D}}$ & 0.0187 & $* * *$ \\
\hline DPA & $0.786^{\mathrm{D}}$ & $0.787^{\mathrm{D}}$ & $0.878^{\mathrm{BC}}$ & $0.895^{\mathrm{BC}}$ & $0.934^{\mathrm{AB}}$ & $0.919^{\mathrm{ABC}}$ & $0.980^{\mathrm{A}}$ & $0.960^{\mathrm{AB}}$ & $0.937^{\mathrm{AB}}$ & $0.856^{\mathrm{CD}}$ & $0.918 \mathrm{~B}^{\mathrm{C}}$ & $0.881 \mathrm{~B}^{\mathrm{C}}$ & 0.0304 & $* * *$ \\
\hline DHA & 0.059 & 0.058 & 0.067 & 0.066 & 0.066 & 0.059 & 0.132 & 0.079 & 0.061 & 0.070 & 0.063 & 0.058 & 0.0174 & ns \\
\hline \multicolumn{15}{|l|}{ FA groups } \\
\hline SFA & $708^{\mathrm{B}}$ & $692^{C}$ & $661^{\mathrm{EF}}$ & $665^{\mathrm{DE}}$ & $668^{\mathrm{D}}$ & $669^{\mathrm{D}}$ & $657^{\mathrm{F}}$ & $670^{\mathrm{D}}$ & $711^{\mathrm{AB}}$ & $718^{\mathrm{A}}$ & $715^{\mathrm{AB}}$ & $709^{\mathrm{AB}}$ & 3.0 & $* * *$ \\
\hline MUFA & $254^{\mathrm{E}}$ & $267^{\mathrm{D}}$ & $292^{\mathrm{AB}}$ & $290^{\mathrm{BC}}$ & $288^{\mathrm{BC}}$ & $287^{\mathrm{BC}}$ & $297^{\mathrm{A}}$ & $286^{\mathrm{C}}$ & $251^{\mathrm{EF}}$ & $246^{\mathrm{E}}$ & $248^{\mathrm{EF}}$ & $253^{\mathrm{EF}}$ & 2.7 & $* * *$ \\
\hline cis MUFA $^{g}$ & $227^{\mathrm{D}}$ & $236^{\mathrm{C}}$ & $250^{\mathrm{B}}$ & $252^{\mathrm{B}}$ & $252^{\mathrm{B}}$ & $251^{\mathrm{B}}$ & $264^{\mathrm{A}}$ & $254^{\mathrm{B}}$ & $225^{\mathrm{D}}$ & $218^{\mathrm{E}}$ & $219^{\mathrm{E}}$ & $224^{\mathrm{DE}}$ & 2.3 & $* * *$ \\
\hline 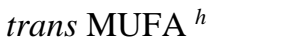 & $27.1^{\mathrm{FG}}$ & $31.1^{\mathrm{DE}}$ & $41.2^{\mathrm{A}}$ & $38.0^{\mathrm{B}}$ & $36.5^{\mathrm{B}}$ & $36.5^{\mathrm{B}}$ & $34.0^{\mathrm{C}}$ & $31.9^{\mathrm{D}}$ & $26.7^{\mathrm{G}}$ & $28.0^{\mathrm{FG}}$ & $28.8^{\mathrm{F}}$ & $29.3^{\mathrm{EF}}$ & 1.02 & $* * *$ \\
\hline PUFA & $37.9^{\mathrm{E}}$ & $41.1^{\mathrm{D}}$ & $47.2^{\mathrm{A}}$ & $44.7^{\mathrm{BC}}$ & $43.6^{\mathrm{C}}$ & $44.3^{\mathrm{BC}}$ & $45.4^{\mathrm{B}}$ & $44.3^{\mathrm{C}}$ & $37.3^{\mathrm{EF}}$ & $36.5^{\mathrm{F}}$ & $36.9^{\mathrm{F}}$ & $37.6^{\mathrm{EF}}$ & 0.51 & $* * *$ \\
\hline cis PUFA $^{i}$ & $26.1^{\mathrm{CD}}$ & $27.5^{\mathrm{AB}}$ & $28.3^{\mathrm{A}}$ & $27.3^{\mathrm{AB}}$ & $26.0^{\mathrm{D}}$ & $26.9^{\mathrm{BC}}$ & $27.8^{\mathrm{AB}}$ & $27.3^{\mathrm{AB}}$ & $24.4^{\mathrm{F}}$ & $25.1^{\mathrm{EF}}$ & $25.1^{\mathrm{EF}}$ & $25.8^{\mathrm{DE}}$ & 0.66 & $* * *$ \\
\hline trans PUFA $^{j}$ & $0.26^{\mathrm{F}}$ & $0.40^{\mathrm{DE}}$ & $0.69^{\mathrm{A}}$ & $0.49^{\mathrm{CD}}$ & $0.54^{\mathrm{BC}}$ & $0.56^{\mathrm{BC}}$ & $0.61^{\mathrm{AB}}$ & $0.52^{\mathrm{BC}}$ & $0.29^{\mathrm{EF}}$ & $0.20^{\mathrm{F}}$ & $0.26^{\mathrm{F}}$ & $0.18^{\mathrm{F}}$ & 0.047 & $* * *$ \\
\hline
\end{tabular}




\begin{tabular}{|c|c|c|c|c|c|c|c|c|c|c|c|c|c|c|}
\hline cis/trans + trans/cis PUFA $^{k}$ & $11.5^{\mathrm{EF}}$ & $13.3^{\mathrm{C}}$ & $18.2^{\mathrm{A}}$ & $16.9^{\mathrm{B}}$ & $17.0^{\mathrm{B}}$ & $16.9^{\mathrm{B}}$ & $17.1^{\mathrm{AB}}$ & $16.5^{\mathrm{B}}$ & $12.6^{\mathrm{DE}}$ & $11.2^{\mathrm{F}}$ & $11.6^{\mathrm{EF}}$ & $11.6^{\mathrm{EF}}$ & 0.55 & $* * *$ \\
\hline $\mathrm{n}-3^{l}$ & $7.74^{\mathrm{F}}$ & $8.76^{\mathrm{D}}$ & $11.71^{\mathrm{A}}$ & $10.80^{\mathrm{B}}$ & $11.01^{\mathrm{B}}$ & $10.75^{\mathrm{B}}$ & $10.99^{\mathrm{B}}$ & $10.02^{\mathrm{C}}$ & $8.10^{\mathrm{EF}}$ & $8.20^{\mathrm{DEF}}$ & F $\quad 8.41^{\mathrm{DEF}}$ & $8.48^{\mathrm{DE}}$ & 0.293 & $* * *$ \\
\hline $\mathrm{n}-6^{m}$ & $20.8^{\mathrm{AB}}$ & $21.7^{\mathrm{A}}$ & $20.9^{\mathrm{ABC}}$ & $20.3^{\mathrm{BCD}}$ & $18.9^{\mathrm{DE}}$ & E $19.9^{\mathrm{BCDE}}$ & $20.6^{\mathrm{ABC}}$ & $20.9^{\mathrm{AB}}$ & $19.0^{\mathrm{E}}$ & $19.4^{\mathrm{DEF}}$ & $\mathrm{F} \quad 19.3^{\mathrm{DEF}}$ & $19.9^{\mathrm{CDEF}}$ & 0.60 & $* * *$ \\
\hline$n-3 / n-6$ & $0.38^{\mathrm{D}}$ & $0.40^{\mathrm{CD}}$ & $0.57^{\mathrm{A}}$ & $0.54^{\mathrm{A}}$ & $0.59^{\mathrm{A}}$ & $0.55^{\mathrm{A}}$ & $0.55^{\mathrm{A}}$ & $0.49^{\mathrm{B}}$ & $0.43^{\mathrm{C}}$ & $0.43 \mathrm{~B}^{\mathrm{C}}$ & $0.44^{\mathrm{BC}}$ & $0.43^{\mathrm{C}}$ & 0.025 & $* * *$ \\
\hline trans $\mathrm{FA}^{n}$ & $2.71^{\mathrm{GH}}$ & $3.13^{\mathrm{DE}}$ & $4.17^{\mathrm{A}}$ & $3.83^{\mathrm{B}}$ & $3.68^{\mathrm{BC}}$ & $3.69^{\mathrm{B}}$ & $3.44^{\mathrm{C}}$ & $3.23^{\mathrm{D}}$ & $2.68^{\mathrm{H}}$ & $2.84^{\mathrm{FGH}}$ & $2.93^{\mathrm{EFG}}$ & $2.97^{\mathrm{EF}}$ & 0.105 & $* * *$ \\
\hline trans FA (exc. VA) & $1.70^{\mathrm{D}}$ & $1.92^{\mathrm{C}}$ & $2.09^{\mathrm{B}}$ & $2.24^{\mathrm{A}}$ & $2.08^{\mathrm{B}}$ & $1.97^{\mathrm{C}}$ & $1.58^{\mathrm{E}}$ & $1.46^{\mathrm{F}}$ & $1.59^{\mathrm{E}}$ & $1.85^{\mathrm{C}}$ & $1.91^{\mathrm{C}}$ & $1.92^{\mathrm{C}}$ & 0.046 & $* * *$ \\
\hline \multicolumn{15}{|l|}{ Indices } \\
\hline \multicolumn{15}{|l|}{ Human health-related } \\
\hline $\mathrm{AI}^{o}$ & $2.90^{\mathrm{B}}$ & $2.63^{\mathrm{C}}$ & $2.24^{\mathrm{E}}$ & $2.26^{\mathrm{E}}$ & $2.32^{\mathrm{DE}}$ & $2.33^{\mathrm{E}}$ & $2.24^{\mathrm{E}}$ & $2.43^{\mathrm{D}}$ & $3.04^{\mathrm{A}}$ & $3.02^{\mathrm{A}}$ & $2.98^{\mathrm{AB}}$ & $2.89^{\mathrm{AB}}$ & 0.048 & $* * *$ \\
\hline $\mathrm{TI}^{p}$ & $3.38^{\mathrm{A}}$ & $3.09^{\mathrm{B}}$ & $2.58^{\mathrm{E}}$ & $2.67^{\mathrm{D}}$ & $2.69^{\mathrm{D}}$ & $2.73^{\mathrm{D}}$ & $2.72^{\mathrm{D}}$ & $2.90^{\mathrm{C}}$ & $3.42^{\mathrm{A}}$ & $3.48^{\mathrm{A}}$ & $3.43^{\mathrm{A}}$ & $3.36^{\mathrm{A}}$ & 0.042 & $* * *$ \\
\hline \multicolumn{15}{|l|}{$\Delta^{9}$-desaturase activity } \\
\hline$\Delta^{9} \mathrm{I}^{r}$ & $0.279^{\mathrm{D}} \mathrm{C}$ & $.293^{\mathrm{C}}$ & $0.317^{\mathrm{A}}$ & $0.318^{\mathrm{A}}$ & $0.317^{\mathrm{A}}$ & $0.314^{\mathrm{A}}$ & $0.319^{\mathrm{A}}$ & $0.308^{\mathrm{B}}$ & $0.277^{\mathrm{D}}$ & $0.269^{\mathrm{E}}$ & $0.271^{\mathrm{E}}$ & $0.276^{\mathrm{DE}}$ & 0.0028 & $* * *$ \\
\hline $\mathrm{C} 14: 1 / \mathrm{C} 14: 0$ & $0.080^{\mathrm{F}}$ & $0.077^{\mathrm{G}}$ & $0.075^{\mathrm{G}}$ & $0.081^{\mathrm{EF}}$ & $0.084^{\mathrm{C}}$ & C $0.084^{\mathrm{CD}}$ & $0.086^{\mathrm{B}}$ & $0.087^{\mathrm{B}}$ & $0.089^{\mathrm{A}}$ & $0.083^{\mathrm{CD}}$ & $0.082^{\mathrm{DE}}$ & $0.081^{\mathrm{EF}}$ & 0.0008 & $* * *$ \\
\hline $\mathrm{C} 16: 1 / \mathrm{C} 16: 0$ & $0.054^{\mathrm{E}}$ & $0.056^{\mathrm{D}}$ & $0.063^{\mathrm{A}}$ & $0.062^{\mathrm{B}}$ & $0.062^{\mathrm{B}}$ & $\begin{array}{l}B \\
{ }^{3}\end{array} 0.060^{C}$ & $0.060^{\mathrm{C}}$ & $0.059^{C}$ & $0.056^{\mathrm{D}}$ & $0.052^{\mathrm{EF}}$ & $0.052^{\mathrm{F}}$ & $0.052^{\mathrm{F}}$ & 0.0006 & $* * *$ \\
\hline OA/C18:0 & $1.918^{\mathrm{DE}}$ & $1.887^{\mathrm{EF}}$ & $=1.940^{\mathrm{C}}$ & $1.926^{\mathrm{CD}}$ & $1.945^{\mathrm{CD}}$ & $1.957^{\mathrm{C}}$ & $2.008^{\mathrm{B}}$ & $2.051^{\mathrm{A}}$ & $2.023^{\mathrm{AB}}$ & $1.841^{\mathrm{G}}$ & $1.838^{\mathrm{G}}$ & $1.853^{\mathrm{FG}}$ & 0.0250 & $* * *$ \\
\hline RA/VA & $0.475^{\mathrm{BC}}$ & $0.476^{\mathrm{BC}}$ & $0.433^{\mathrm{D}}$ & $0.527^{\mathrm{A}}$ & $0.537^{\mathrm{A}}$ & $0.491^{\mathrm{B}}$ & $0.449^{\mathrm{CD}}$ & $0.451^{\mathrm{CD}}$ & $0.528^{\mathrm{A}}$ & $0.483^{\mathrm{B}}$ & $0.489^{\mathrm{B}}$ & $0.474^{\mathrm{BC}}$ & 0.0113 & $* * *$ \\
\hline
\end{tabular}

${ }^{a}$ In September, there was a missing sample of free-range milk in the analysis of basic composition and the mean on this set of parameters was calculated from nine samples

${ }^{b}$ Significances were declared at $* * *, \mathrm{P}<0.001$; **, $\mathrm{P}<0.01 ; *, \mathrm{P}<0.05 ; \%, 0.05<\mathrm{P}<0.10$ (trend); ns, $\mathrm{P}>0.10$ (non-significant). Means for month within a row with different upper case letters are significantly different according to Fisher's Least Significant Difference test $(\mathrm{P}<0.05)$

${ }^{c}$ Somatic cell count

${ }^{d}$ Saturated FA: C4:0, C5:0, C6:0, C7:0, C8:0, C9:0, C10:0, C11:0, C12:0, C13:0, C13:0iso, C13:0anteiso, C13:0, C14:0iso, C14:0, C15:0anteiso, C15:0, C16:0iso, C16:0, C17:0iso, C17:0, C18:0iso, C18:0, C20:0, C22:0, C24:0

${ }^{e}$ Monounsaturated FA: $c 9 \mathrm{C} 10: 1, c 10 \quad \mathrm{C} 11: 1, c 9 \mathrm{C} 12: 1, c 9 \mathrm{C} 13: 1, t 9$ 14:1, $c 9 \mathrm{C} 14: 1, c 10 \mathrm{C} 15: 1, t 7+\mathrm{t} 8 \mathrm{C} 16: 1, t 9 \mathrm{C} 16: 1, t 11+t 12+t 13 \mathrm{C} 16: 1, c 9 \mathrm{C} 16: 1(\mathrm{co}-\mathrm{elutes}$ with C17:0anteiso), $c 11$ C16:1, $c 13$ C16:1, $t 10$ C17:1, $c 9$ C17:1, $t 4$ C18:1, t5 C18:1, t6+t7+t8 C18:1, $t 9$ C18:1, $t 10$ C18:1, $t 11$ C18:1 (VA), $c 6+t 12$ C18:1, $c 9$ C18:1 (OA), $t 15$ C18:1, $c 11$ C18:1, $c 12$ C18:1, $c 13$ C18:1, $t 16+c 14$ C18:1, $c 15$ C18:1 (co-elutes with C19:0), $c 16$ C18:1, $c 5$ C20:1, $c 8$ C20:1, $c 11$ C20:1, $c 13$ C22:1, $c 15$ C24:1

${ }_{f}^{f}$ Polyunsaturated FA: $t 11 t 15 \mathrm{C} 18: 2, t 9 t 12 \mathrm{C} 18: 2, c 9 t 13 \mathrm{C} 18: 2, c 10 t 14 \mathrm{C} 18: 2, c 9 t 14 \mathrm{C} 18: 2, c 9 t 12 \mathrm{C} 18: 2, t 9 c 12 \mathrm{C} 18: 2, t 11 c 15 \mathrm{C} 18: 2, c 9 c 12 \mathrm{C} 18: 2$ (LA), $t 12 c 15 \mathrm{C} 18: 2$ (coelutes with $c 9 \mathrm{C} 19: 1$ ), $c 6 c 9 c 12 \mathrm{C} 18: 3, c 9 c 12 c 15 \mathrm{C} 18: 3$ (ALNA), $c 9 c 11 \mathrm{C} 18: 2$ conjugated (RA) (co-elutes with $t 7 c 9+t 8 c 10+t 6 c 8 \mathrm{C} 18: 2$ ), other C18:2 conjugated FA of unknown isomerism, $c 11 c 14 \mathrm{C} 20: 2, c 8 c 11 c 14 \mathrm{C} 20: 3, c 11 c 14 c 17 \mathrm{C} 20: 3, c 5 c 8 c 11 c 14 \mathrm{C} 20: 4, c 13 c 16 \mathrm{C} 22: 2$, EPA, $c 13 c 16 c 19 \mathrm{C} 22: 3$, DPA, DHA

${ }^{g}$ cis MUFA: $c 9$ C10:1, $c 10$ C11:1, $c 9$ C12:1, $c 9$ C13:1, $c 9$ C14:1, c10 C15:1, $c 9$ C16:1 (co-elutes with C17:0anteiso), $c 11$ C16:1, $c 13$ C16:1, $c 9$ C17:1, $c 6$ C18:1 (co-elutes with $t 12$ C18:1), OA, $c 11$ C18:1, $c 12$ C18:1, $c 13$ C18:1, $c 14$ C18:1 (co-elutes with $t 16$ C18:1), $c 15$ C18:1 (co-elutes with C19:0), $c 16$ C18:1, $c 5$ C20:1, $c 8$ C20:1, $c 11$ C20:1, c13 C22:1, $c 15$ C24:1

${ }^{h}$ trans MUFA: $t 9$ 14:1, $t 7+\mathrm{t} 8 \mathrm{C} 16: 1, t 9 \mathrm{C} 16: 1, t 11+t 12+t 13 \mathrm{C} 16: 1, t 10 \mathrm{C} 17: 1, t 4 \mathrm{C} 18: 1, t 5 \mathrm{C} 18: 1, t 6+t 7+t 8 \mathrm{C} 18: 1, t 9 \mathrm{C} 18: 1, t 10 \mathrm{C} 18: 1, \mathrm{VA}, t 12 \mathrm{C} 18: 1 \mathrm{co-elutes}$ with $\left.c 6 \mathrm{C} 18: 1\right)$ t15 C18:1, $t 16 \mathrm{C} 18: 1$ (co-elutes with $c 14 \mathrm{C} 18: 1$ )

${ }^{i}$ cis PUFA: LA, ALNA, c11c14 C20:2, c8c11c14 C20:3, c11c14c17 C20:3, c5c8c11c14 C20:4, c13c16 C22:2, EPA, c13c16c19 C22:3, DPA, DHA

i trans PUFA: $t 11 t 15 \mathrm{C} 18: 2, t 9 t 12 \mathrm{C} 18: 2$

${ }^{k}$ cis/trans + trans/cis PUFA: $c 9 t 13$ C18:2, $c 10 t 14$ C18:2, $c 9 t 14$ C18:2, $c 9 t 12$ C18:2, $t 9 c 12$ C18:2, $t 11 c 15$ C18:2, $t 12 c 15$ C18:2 (co-elutes with $c 9$ C19:1), RA (co-elutes with $t 7 c 9+t 8 c 10+t 6 c 8 \mathrm{C} 18: 2)$, other $\mathrm{C} 18: 2$ conjugated FA of unknown isomerism

${ }^{l}$ omega-3 PUFA (n-3): $t 11 t 15$ C18:2, $t 11 c 15$ C18:2, $t 12 c 15$ C18:2 (co-elutes with $c 9$ C19:1), ALNA, $c 11 c 14 c 17$ C20:3, EPA, $c 13 c 16 c 19$ C22:3, DPA, DHA

${ }^{m}$ omega-6 PUFA (n-6): $t 9 t 12$ C18:2, $c 9 t 12$ C18:2, $t 9 c 12$ C18:2, LA, $c 6 c 9 c 12$ C18:3, $c 11 c 14$ C20:2, $c 8 c 11 c 14$ C20:3, $c 5 c 8 c 11 c 14$ C $20: 4, c 13 c 16$ C22:2, $c 7 c 10 c 13 c 16$ C22:4 
${ }^{n}$ trans FA: $t 9$ C14:1, $t 9$ C16:1, $t 11+t 12+t 13$ C16:1, $t 10$ C17:1, $t 4$ C18:1, $t 5$ C18:1, $t 6+t 7+t 8$ C18:1, $t 9$ C18:1, $t 10$ C18:1, VA, $t 12$ C18:1, $t 15$ C18:1, $t 16$ C18:1, $t 11 t 15$ C18:2, $t 9 t 12 \mathrm{C} 18: 2, t 12 t 15 \mathrm{C} 18: 2$

${ }^{o}$ Atherogenicity index $=(\mathrm{C} 12: 0+4 \mathrm{x}$ C14:0 + C16:0) $/($ MUFA + PUFA $)$, as described in Srednicka-Tober et al. (2016)

${ }^{p}$ Thrombogenicity index $=(\mathrm{C} 14: 0+\mathrm{C} 16: 0+\mathrm{C} 18: 0) /[(0.5 \times \mathrm{MUFA})+(0.5 \mathrm{x} \mathrm{n}-6)+(3 \times \mathrm{n}-3)+(\mathrm{n}-3 / \mathrm{n}-6)]$, as described in Srednicka-Tober et al. $(2016)$

${ }^{r} \Delta^{9}$-desaturase activity index $=(\mathrm{c} 9 \mathrm{C} 14: 1+\mathrm{c} 9 \mathrm{C} 16: 1+\mathrm{OA}+\mathrm{RA}) /(\mathrm{c} 9 \mathrm{C} 14: 1+\mathrm{c} 9 \mathrm{C} 16: 1+\mathrm{OA}+\mathrm{RA}+\mathrm{C} 14: 0+\mathrm{C} 16: 0+\mathrm{C} 18: 0+\mathrm{VA})$, as proposed by Kay et al. (2004) 
Table 3

Means (and average SE) and ANOVA P-values for the effect of production system (conventional, CON; organic, ORG; free-range, FR) on the estimated intakes of fatty acid (FA) intakes from dairy products, using milk FA profiles measured in this study.

\begin{tabular}{|c|c|c|c|c|c|c|c|c|c|c|c|c|c|c|c|c|}
\hline \multirow{2}{*}{$\frac{\text { Intakes }}{\text { Fat }(\mathbf{g} / \mathbf{d})^{a}}$} & Age group & \multicolumn{5}{|c|}{ Males } & \multicolumn{5}{|c|}{ Females } & \multicolumn{5}{|c|}{ All } \\
\hline & $4-10$ & \multicolumn{5}{|c|}{58.4} & \multicolumn{5}{|c|}{56.2} & \multicolumn{5}{|c|}{57.4} \\
\hline & $11-18$ & \multicolumn{5}{|c|}{73.8} & \multicolumn{5}{|c|}{59.8} & \multicolumn{5}{|c|}{67.0} \\
\hline & $19-64$ & \multicolumn{5}{|c|}{77.7} & \multicolumn{5}{|c|}{60.1} & \multicolumn{5}{|c|}{68.8} \\
\hline & $65+$ & \multicolumn{5}{|c|}{74.1} & \multicolumn{5}{|c|}{57.8} & \multicolumn{5}{|c|}{65.0} \\
\hline Milk fat ${ }^{a}$ & $4-10$ & \multicolumn{5}{|c|}{22.2} & \multicolumn{5}{|c|}{23.0} & \multicolumn{5}{|c|}{22.6} \\
\hline (\% fat) & $11-18$ & \multicolumn{5}{|c|}{15.7} & \multicolumn{5}{|c|}{15.1} & \multicolumn{5}{|c|}{154} \\
\hline & $19-64$ & \multicolumn{5}{|c|}{15.8} & \multicolumn{5}{|c|}{17.2} & & & 16.5 & & \\
\hline & $65+$ & & & 22.4 & & & & & 24.4 & & & & & 23.5 & & \\
\hline & & & & Male & & & & & Femal & & & & & All & & \\
\hline Age group & FA intakes (g/d) & CON & ORG & FR & SE & $\begin{array}{l}\text { ANOVA } \\
\text { P-value }\end{array}$ & CON & ORG & FR & SE & $\begin{array}{l}\text { ANOVA } \\
\text { P-value }\end{array}$ & CON & ORG & FR & SE & $\begin{array}{l}\text { ANOVA } \\
\text { P-value }^{b}\end{array}$ \\
\hline $4-10$ & $\mathrm{SFA}^{c}(\mathrm{~g} / \mathrm{d})$ & 8.3 & 8.3 & 8.4 & 0.05 & $\mathrm{~ns}$ & 8.3 & 8.2 & 8.3 & 0.05 & $\mathrm{~ns}$ & 8.3 & 8.3 & 8.4 & 0.05 & $\mathrm{~ns}$ \\
\hline & $\operatorname{MUFA}^{d}(\mathrm{~g} / \mathrm{d})$ & 3.3 & 3.3 & 3.3 & 0.04 & ns & 3.3 & 3.3 & 3.3 & 0.04 & ns & 3.3 & 3.3 & 3.3 & 0.04 & ns \\
\hline & PUFA $^{e}(\mathrm{mg} / \mathrm{d})$ & $480^{\mathrm{B}}$ & $540^{\mathrm{A}}$ & $464^{\mathrm{B}}$ & 8.5 & $* * *$ & $479^{\mathrm{B}}$ & $539^{\mathrm{A}}$ & $462^{\mathrm{B}}$ & 8.5 & $* * *$ & $480^{\mathrm{B}}$ & $540^{\mathrm{A}}$ & $464^{\mathrm{B}}$ & 8.5 & $* * *$ \\
\hline & $\mathrm{n}-3^{f}(\mathrm{mg} / \mathrm{d})$ & $96^{\mathrm{B}}$ & $141^{\mathrm{A}}$ & $105^{\mathrm{B}}$ & 3.3 & $* * *$ & $96^{\mathrm{B}}$ & $141^{\mathrm{A}}$ & $105^{\mathrm{B}}$ & 3.3 & $* * *$ & $96^{\mathrm{B}}$ & $142^{\mathrm{A}}$ & $105^{\mathrm{B}}$ & 3.3 & $* * *$ \\
\hline & ALNA (mg/d) & $53^{\mathrm{B}}$ & $81^{\mathrm{A}}$ & $58^{\mathrm{B}}$ & 1.7 & $* * *$ & $53^{\mathrm{B}}$ & $81^{\mathrm{A}}$ & $57^{\mathrm{B}}$ & 1.7 & $* * *$ & $53^{\mathrm{B}}$ & $81^{\mathrm{A}}$ & $58^{\mathrm{B}}$ & 1.7 & $* * *$ \\
\hline & $\mathrm{EPA}+\mathrm{DHA}(\mathrm{mg} / \mathrm{d})$ & $7^{\mathrm{B}}$ & $9^{\mathrm{A}}$ & $7^{\mathrm{B}}$ & 0.2 & $* * *$ & $7^{\mathrm{B}}$ & $9^{\mathrm{A}}$ & $7^{\mathrm{B}}$ & 0.2 & $* * *$ & $7^{\mathrm{B}}$ & $9^{\mathrm{A}}$ & $7^{\mathrm{B}}$ & 0.2 & $* * *$ \\
\hline & trans $\mathrm{FA}^{g}(\mathrm{mg} / \mathrm{d})$ & $378^{\mathrm{B}}$ & $429^{\mathrm{A}}$ & $367^{\mathrm{B}}$ & 10.4 & $* * *$ & $377^{\mathrm{B}}$ & $428^{\mathrm{A}}$ & $366^{\mathrm{B}}$ & 10.4 & $* * *$ & $378^{\mathrm{B}}$ & $430^{\mathrm{A}}$ & $367^{\mathrm{B}}$ & 10.4 & $* * *$ \\
\hline & $\operatorname{trans} \mathrm{FA}^{g}($ exc. VA) $(\mathrm{mg} / \mathrm{d})$ & 230 & 223 & 218 & 5.2 & $\mathrm{~ns}$ & 230 & 222 & 218 & 5.2 & ns & 230 & 223 & 218 & 5.2 & $\mathrm{~ns}$ \\
\hline $11-18$ & $\operatorname{SFA}^{c}(\mathrm{~g} / \mathrm{d})$ & 7.4 & 7.4 & 7.5 & 0.05 & ns & 5.8 & 5.8 & 5.8 & 0.04 & ns & 6.6 & 6.6 & 6.7 & 0.04 & $\mathrm{~ns}$ \\
\hline & $\operatorname{MUFA}^{d}(\mathrm{~g} / \mathrm{d})$ & 2.9 & 2.9 & 2.9 & 0.04 & ns & 2.3 & 2.3 & 2.3 & 0.03 & ns & 2.6 & 2.6 & 2.6 & 0.03 & ns \\
\hline & $\mathrm{PUFA}^{e}(\mathrm{mg} / \mathrm{d})$ & $429^{\mathrm{B}}$ & $483^{\mathrm{A}}$ & $414^{\mathrm{B}}$ & 7.6 & $* * *$ & $334^{\mathrm{B}}$ & $376^{\mathrm{A}}$ & $323^{\mathrm{B}}$ & $\begin{array}{r}0.00 \\
5.9\end{array}$ & $* * *$ & $382^{\mathrm{B}}$ & $430^{\mathrm{A}}$ & $369^{\mathrm{B}}$ & 6.8 & $* * *$ \\
\hline & $\mathrm{n}-3^{f}(\mathrm{mg} / \mathrm{d})$ & $86^{\mathrm{B}}$ & $126^{\mathrm{A}}$ & $94^{\mathrm{B}}$ & 3.0 & $* * *$ & $67^{\mathrm{B}}$ & $99^{\mathrm{A}}$ & $73^{\mathrm{B}}$ & 2.3 & $* * *$ & $76^{\mathrm{B}}$ & $113^{\mathrm{A}}$ & $83^{\mathrm{B}}$ & 2.6 & $* * *$ \\
\hline & $\operatorname{ALNA}(\mathrm{mg} / \mathrm{d})$ & $47^{\mathrm{B}}$ & $73^{\mathrm{A}}$ & $51^{\mathrm{B}}$ & 1.5 & $* * *$ & $37^{\mathrm{B}}$ & $57^{\mathrm{A}}$ & $40^{\mathrm{B}}$ & 1.2 & $* * *$ & $42^{\mathrm{B}}$ & $65^{\mathrm{A}}$ & $46^{\mathrm{B}}$ & 1.4 & $* * *$ \\
\hline & $\mathrm{EPA}+\mathrm{DHA}(\mathrm{mg} / \mathrm{d})$ & $6^{\mathrm{B}}$ & $8^{\mathrm{A}}$ & $7^{\mathrm{B}}$ & 0.2 & $* * *$ & $5^{\mathrm{B}}$ & $6^{\mathrm{A}}$ & $5^{\mathrm{B}}$ & 0.1 & $* * *$ & $5^{\mathrm{B}}$ & $7^{\mathrm{A}}$ & $6^{\mathrm{B}}$ & 0.2 & $* * *$ \\
\hline & trans $\mathrm{FA}^{g}(\mathrm{mg} / \mathrm{d})$ & $338^{\mathrm{B}}$ & $384^{\mathrm{A}}$ & $328^{\mathrm{B}}$ & 9.3 & $* * *$ & $263^{\mathrm{B}}$ & $299^{\mathrm{A}}$ & $255^{\mathrm{B}}$ & 7.2 & $* * *$ & $301^{\mathrm{B}}$ & $342^{\mathrm{A}}$ & $292^{\mathrm{B}}$ & 8.3 & $* * *$ \\
\hline & trans $\mathrm{FA}^{g}(\mathrm{exc} . \mathrm{VA})(\mathrm{mg} / \mathrm{d})$ & 206 & 199 & 195 & 4.7 & ns & 160 & 155 & 152 & 3.6 & ns & 183 & 177 & 174 & 4.2 & $\mathrm{~ns}$ \\
\hline $19-64$ & $\mathrm{SFA}^{c}(\mathrm{~g} / \mathrm{d})$ & 7.9 & 7.8 & 7.9 & 0.05 & ns & 6.6 & 6.6 & 6.7 & 0.04 & ns & 7.3 & 7.2 & 7.3 & 0.05 & ns \\
\hline & $\operatorname{MUFA}^{d}(\mathrm{~g} / \mathrm{d})$ & 3.1 & 3.1 & 3.1 & 0.04 & ns & 2.6 & 2.6 & 2.6 & 0.03 & ns & 2.9 & 2.9 & 2.9 & 0.04 & $\mathrm{~ns}$ \\
\hline & PUFA $^{e}(\mathrm{mg} / \mathrm{d})$ & $455^{\mathrm{B}}$ & $511^{\mathrm{A}}$ & $439^{\mathrm{B}}$ & 8.0 & $* * *$ & $383^{\mathrm{B}}$ & $431^{\mathrm{A}}$ & $370^{\mathrm{B}}$ & 6.8 & $* * *$ & $420^{\mathrm{B}}$ & $473^{\mathrm{A}}$ & $406^{\mathrm{B}}$ & 7.4 & $* * *$ \\
\hline & $\mathrm{n}-3^{f}(\mathrm{mg} / \mathrm{d})$ & $91^{\mathrm{B}}$ & $134^{\mathrm{A}}$ & $99^{\mathrm{B}}$ & 3.1 & $* * *$ & $76^{\mathrm{B}}$ & $113^{\mathrm{A}}$ & $84^{\mathrm{B}}$ & 2.6 & $* * *$ & $84^{\mathrm{B}}$ & $124^{\mathrm{A}}$ & $92^{\mathrm{B}}$ & 2.9 & $* * *$ \\
\hline & ALNA & $50^{\mathrm{B}}$ & $77^{\mathrm{A}}$ & $55^{\mathrm{B}}$ & 1.6 & $* * *$ & $42^{\mathrm{B}}$ & $65^{\mathrm{A}}$ & $46^{\mathrm{B}}$ & 1.4 & $* * *$ & $46^{\mathrm{B}}$ & $71^{\mathrm{A}}$ & $50^{\mathrm{B}}$ & 1.5 & $* * *$ \\
\hline
\end{tabular}




\section{$\mathrm{EPA}+\mathrm{DHA}$}

trans $\mathrm{FA}^{g}(\mathrm{mg} / \mathrm{d})$

$65+$

trans ${ }^{g} \mathrm{FA}$

$\mathrm{SFA}^{c}(\mathrm{~g} / \mathrm{d})$

$\operatorname{MUFA}^{d}(\mathrm{~g} / \mathrm{d})$

$\operatorname{PUFA}^{e}(\mathrm{mg} / \mathrm{d})$

$\mathrm{n}-3^{f}(\mathrm{mg} / \mathrm{d})$

ALNA

EPA+DHA

trans $\mathrm{FA}^{g}(\mathrm{mg} / \mathrm{d})$

trans ${ }^{g} \mathrm{FA}($ exc. VA) $(\mathrm{mg} / \mathrm{d})$
$\begin{array}{lllll}6^{\mathrm{B}} & 9^{\mathrm{A}} & 7^{\mathrm{B}} & 0.2 & * * *\end{array}$

$\begin{array}{lllll}358^{\mathrm{B}} & 407^{\mathrm{A}} & 347^{\mathrm{B}} & 9.8 & * * *\end{array}$

$\begin{array}{llllll}218 & 211 & 207 & 5.0 & \text { ns }\end{array}$

$\begin{array}{lllll}10.7 & 10.6 & 10.7 & 0.07 & \text { ns }\end{array}$

$\begin{array}{lllll}4.2 & 4.2 & 4.2 & 0.06 & \text { ns }\end{array}$

$615^{\mathrm{B}} \quad 692^{\mathrm{A}} 593^{\mathrm{B}} 10.9$ ***

$\begin{array}{lllll}123^{\mathrm{B}} & 181^{\mathrm{A}} & 134^{\mathrm{B}} & 4.2 & * * *\end{array}$

$\begin{array}{lllll}68^{\mathrm{B}} & 104^{\mathrm{A}} & 74^{\mathrm{B}} & 2.2\end{array} * * *$

$9^{\mathrm{B}} \quad 12^{\mathrm{A}} \quad 9^{\mathrm{B}} \quad 0.3 \quad * * *$

$\begin{array}{lllll}484^{\mathrm{B}} & 550^{\mathrm{A}} & 469^{\mathrm{B}} & 13.3\end{array}$ ***

$\begin{array}{lllll}295 & 285 & 280 & 6.7 & \mathrm{~ns}\end{array}$

$\begin{array}{rrrrc}5^{\mathrm{B}} & 7^{\mathrm{A}} & 6^{\mathrm{B}} & 0.2 & * * * \\ 301^{\mathrm{B}} & 342^{\mathrm{A}} & 292^{\mathrm{B}} & 8.3 & * * * \\ 184 & 178 & 174 & 4.2 & \mathrm{~ns} \\ 9.0 & 9.0 & 9.1 & 0.06 & \mathrm{~ns} \\ 3.6 & 3.6 & 3.5 & 0.05 & \mathrm{~ns} \\ 522^{\mathrm{B}} & 588^{\mathrm{A}} & 504^{\mathrm{B}} & 9.2 & * * * \\ 104^{\mathrm{B}} & 154^{\mathrm{A}} & 114^{\mathrm{B}} & 3.6 & * * * \\ 58^{\mathrm{B}} & 88^{\mathrm{A}} & 63^{\mathrm{B}} & 1.9 & * * * \\ 7^{\mathrm{B}} & 10^{\mathrm{A}} & 8^{\mathrm{B}} & 0.2 & * * * \\ 411^{\mathrm{B}} & 467^{\mathrm{A}} & 399^{\mathrm{B}} & 11.3 & * * * \\ 251 & 242 & 238 & 5.7 & \mathrm{~ns}\end{array}$

${ }^{a}$ Intake data of fats and fatty acids of Year 1 of the National Diet and Nutrition Survey rolling programme 2008-2009, as presented by Bates et al. (2014). For the purposes of the intake calculations, this study assumes that all dairy products produced in the UK have the same FA profile as the whole milk analysed.

${ }^{b}$ Significances were declared at ***, $\mathrm{P}<0.001$; **, $\mathrm{P}<0.01 ; *, \mathrm{P}<0.05 ; \dagger, 0.05<\mathrm{P}<0.10$ (trend); ns, $\mathrm{P}>0.10$ (non-significant). Means for production system within a row and gender with different upper case letters are significantly different according to Fisher's Least Significant Difference test $(\mathrm{P}<0.05)$

${ }^{d}$ Saturated FA: C4:0, C5:0, C6:0, C7:0, C8:0, C9:0, C10:0, C11:0, C12:0, C13:0, C13:0iso, C13:0anteiso, C13:0, C14:0iso, C14:0, C15:0anteiso, C15:0, C16:0iso, C16:0, C17:0iso, C17:0, C18:0iso, C18:0, C20:0, C22:0, C24:0

$e$ Monounsaturated FA: $c 9 \mathrm{C} 10: 1, c 10 \quad \mathrm{C} 11: 1, c 9 \mathrm{C} 12 \cdot 1, c 9 \mathrm{C} 13: 1, t 914 \cdot 1, c 9 \mathrm{C} 14 \cdot 1, c 10 \mathrm{C} 15 \cdot 1, t 7+\mathrm{t} 8 \mathrm{C} 16 \cdot 1, t 9 \mathrm{C} 16: 1, t 11+t 12+t 13 \mathrm{C} 16: 1$, $c 9 \mathrm{C} 16: 1$ (co-elutes with C17:0anteiso), $c 11 \mathrm{C} 16: 1, c 13 \mathrm{C} 16: 1, t 10 \mathrm{C} 17: 1, c 9 \mathrm{C} 17: 1, t 4 \mathrm{C} 18: 1, t 5 \mathrm{C} 18: 1, t 6+t 7+t 8 \mathrm{C} 18: 1, t 9 \mathrm{C} 18: 1, t 10 \mathrm{C} 18: 1, t 11$ C18:1 (VA), $c 6+t 12$ C18:1, $c 9$ C18:1 (OA), $t 15$ C18:1, $c 11$ C18:1, $c 12$ C18:1, $c 13$ C18:1, $t 16+c 14$ C18:1, $c 15$ C18:1 (co-elutes with C19:0), $c 16$ C18:1, 5 C20:1, 8 C20:1, 11 C20:1, 13 C22:1, 15 C24:1

${ }^{f}$ Polyunsaturated FA: $t 11 t 15$ C18:2, $t 9 t 12$ C18:2, $c 9 t 13$ C18:2, $c 10 t 14$ C18:2, $c 9 t 14$ C18:2, $c 9 t 12$ C18:2, $t 9 c 12$ C18:2, $t 11 c 15$ C18:2, $c 9 c 12$ C18:2 (LA), $t 12 c 15 \mathrm{C} 18: 2$ (co-elutes with $c 9 \mathrm{C} 19: 1), c 6 c 9 c 12 \mathrm{C} 18: 3, c 9 c 12 c 15 \mathrm{C} 18: 3$ (ALNA), $c 9 c 11$ C18:2 conjugated (RA) (co-elutes with

$t 7 c 9+t 8 c 10+t 6 c 8 \mathrm{C} 18: 2)$, other $\mathrm{C} 18: 2$ conjugated FA of unknown isomerism, $c 11 c 14 \mathrm{C} 20: 2, c 8 c 11 c 14 \mathrm{C} 20: 3, c 11 c 14 c 17 \mathrm{C} 20: 3, c 5 c 8 c 11 c 14$

C20:4, $c 13 c 16$ C22:2, EPA, $c 13 c 16 c 19$ C22:3, DPA, DHA

${ }^{g}$ omega-3 PUFA (n-6): $t 11 t 15$ C18:2, $t 11 c 15$ C18:2, $t 12 c 15$ C18:2 (co-elutes with $c 9$ C19:1), ALNA, $c 11 c 14 c 17$ C20:3, EPA, $c 13 c 16 c 19$ C22:3, DPA, DHA

${ }^{h}$ omega-6 PUFA (n-6): $t 9 t 12$ C18:2, $c 9 t 12$ C18:2, $t 9 c 12$ C18:2, LA, $c 6 c 9 c 12$ C18:3, $c 11 c 14$ C20:2, $c 8 c 11 c 14$ C20:3, $c 5 c 8 c 11 c 14$ C20:4, $c 13 c 16$ $\mathrm{C} 22: 2, c 7 c 10 c 13 c 16 \mathrm{C} 22: 4$

${ }^{i}$ trans FA: $t 9 \mathrm{C} 14: 1, t 9 \mathrm{C} 16: 1, t 11+t 12+t 13 \mathrm{C} 16: 1, t 10 \mathrm{C} 17: 1, t 4 \mathrm{C} 18: 1, t 5 \mathrm{C} 18: 1, t 6+t 7+t 8 \mathrm{C} 18: 1, t 9 \mathrm{C} 18: 1, t 10 \mathrm{C} 18: 1, \mathrm{VA}, t 12 \mathrm{C} 18: 1, t 15 \mathrm{C} 18: 1$, $t 16 \mathrm{C} 18: 1, t 11 t 15 \mathrm{C} 18: 2, t 9 t 12 \mathrm{C} 18: 2, t 12 t 15 \mathrm{C} 18: 2$ 

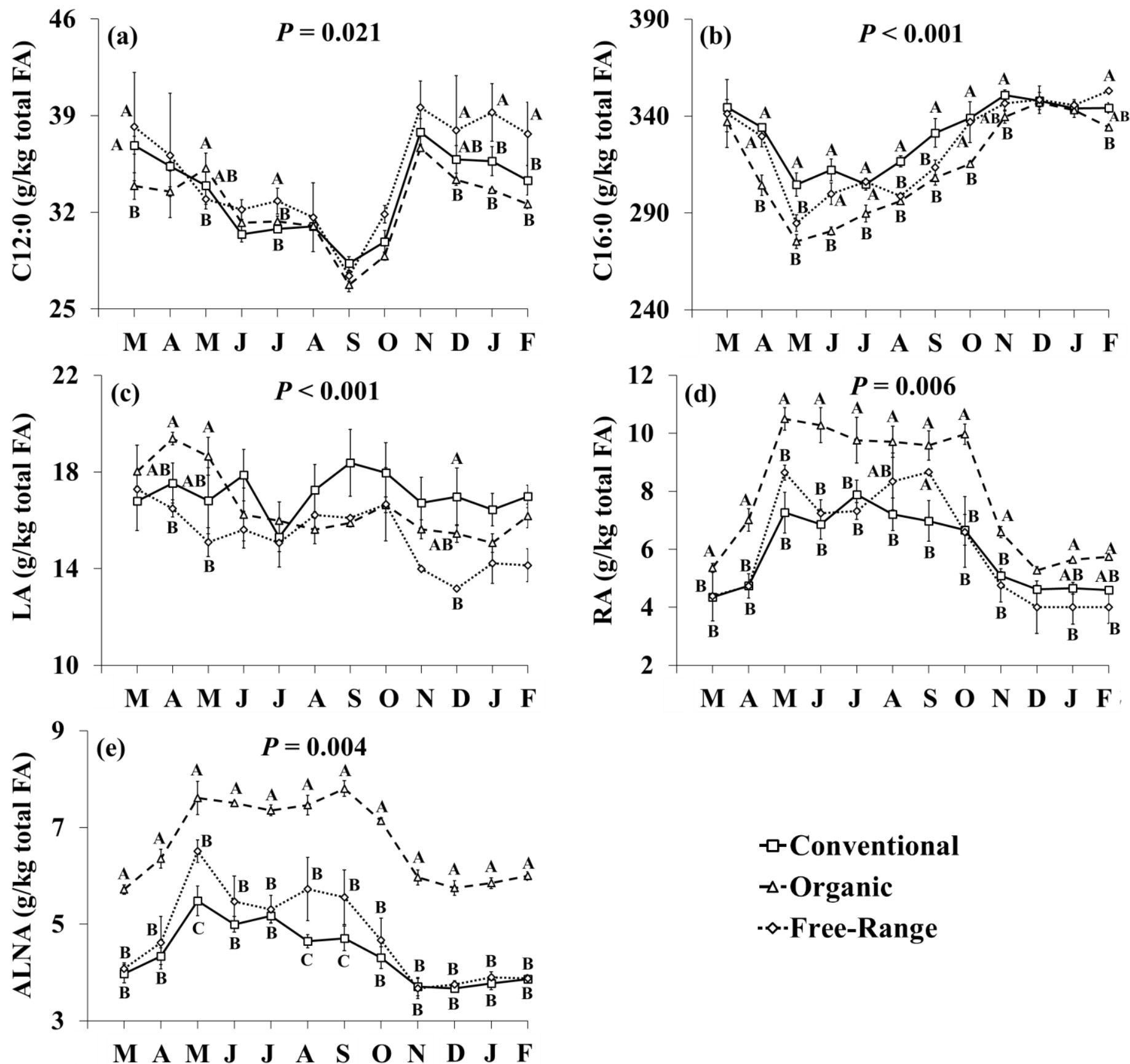

Figure 1. Interaction means $\pm \mathrm{SE}$ (error bars) for the effects of production system (conventional, CON; organic, ORG; free-range, FR) and month (in order of appearance from left to right in Axis Y: M, March; A, April; M, May; J, June; J, July; A, August; S, September; O, October; N, November; D, December; J, January; F, February) on the concentrations of (a) C12:0, (b) C16:0, (c) linoleic acid (LA), (d) rumenic acid (RA) and (e) $\alpha$-linolenic acid (ALNA) of milk collected from retail outlets during the year. P represents the ANOVA Pvalue for the interaction. Means for production system and within a month with different upper case letters are significantly different according to Fisher's Least Significant Difference test $(\mathrm{P}<0.05)$. 

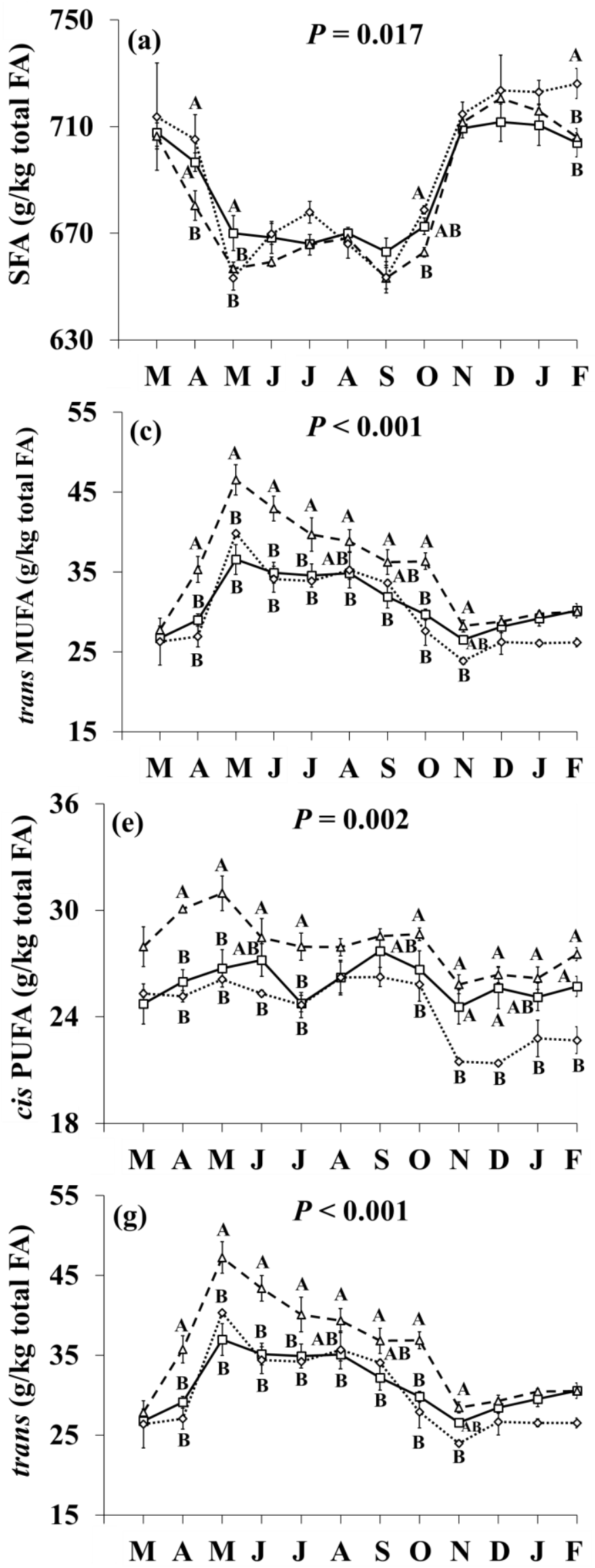
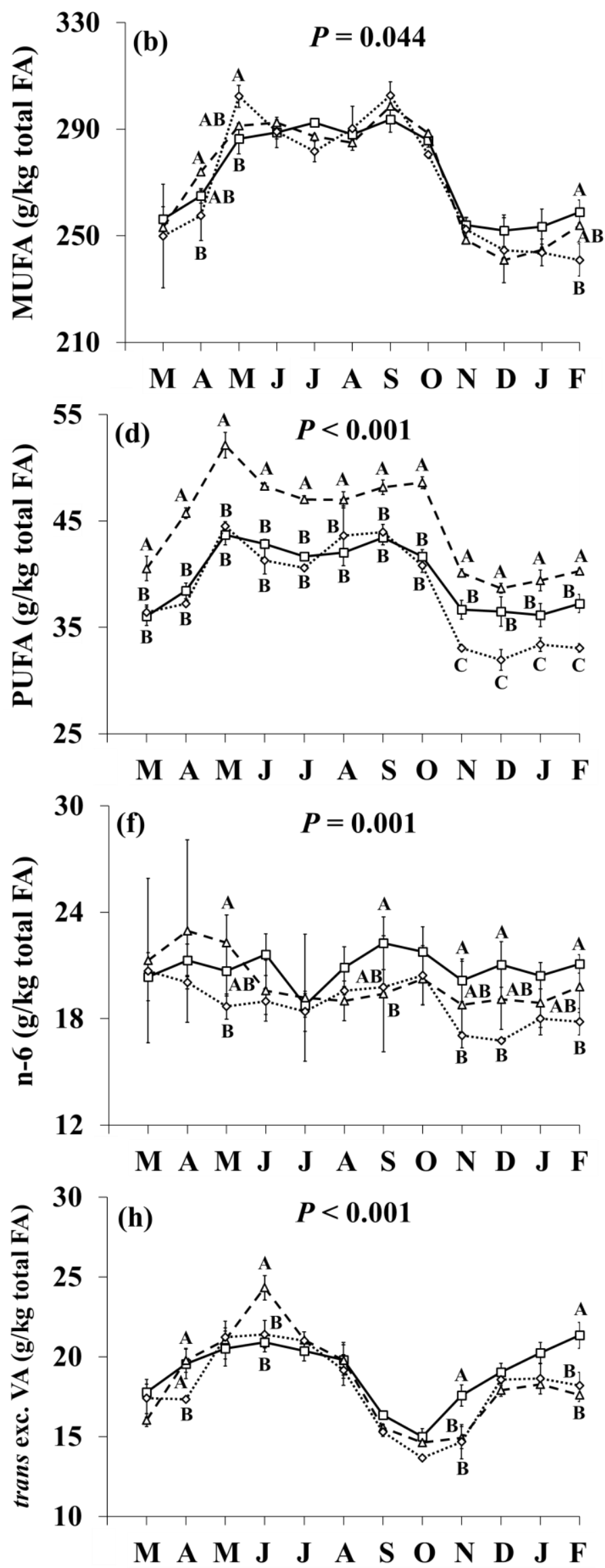


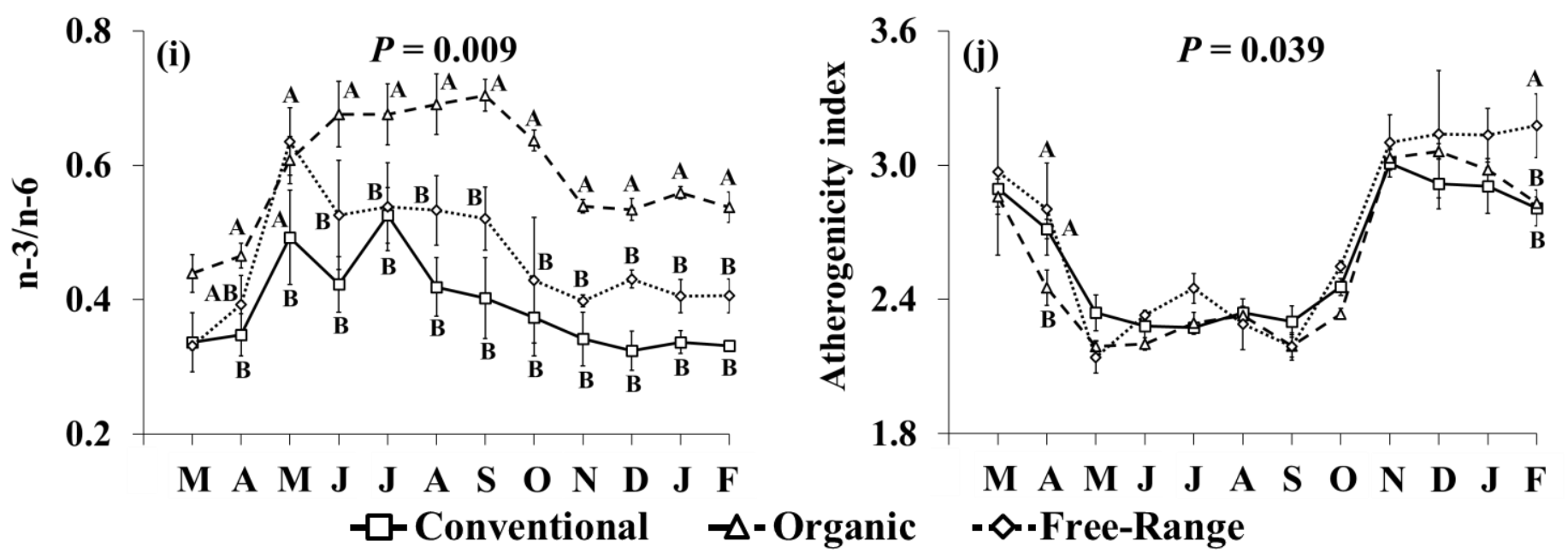

Figure 2. Interaction means \pm SE (error bars) for the effects of production system (conventional, CON; organic, ORG; free-range, FR) and month (in order of appearance from left to right in Axis Y: M, March; A, April; M, May; J, June; J, July; A, August; S, September; O, October; N, November; D, December; J, January; F, February) on the concentrations of (a) saturated fatty acids (SFA), (b) monounsaturated fatty acids (MUFA), (c) trans MUFA, (d) polyunsaturated fatty acids (PUFA), (e) cis PUFA, (f) omega-6 PUFA (n-6), (g) trans FA, trans FA (h) excluding VA, (i) the ratio of omega-3 PUFA/omega-6 PUFA (n-3/n-6) and (j) the atherogenicity index (as proposed by Srednicka-Tober et al. (2016)) of milk collected from retail outlets during the year. P represents the ANOVA P-value for the interaction. Means for production system and within a month with different upper case letters are significantly different according to Fisher's Least Significant Difference test $(\mathrm{P}<0.05)$. 


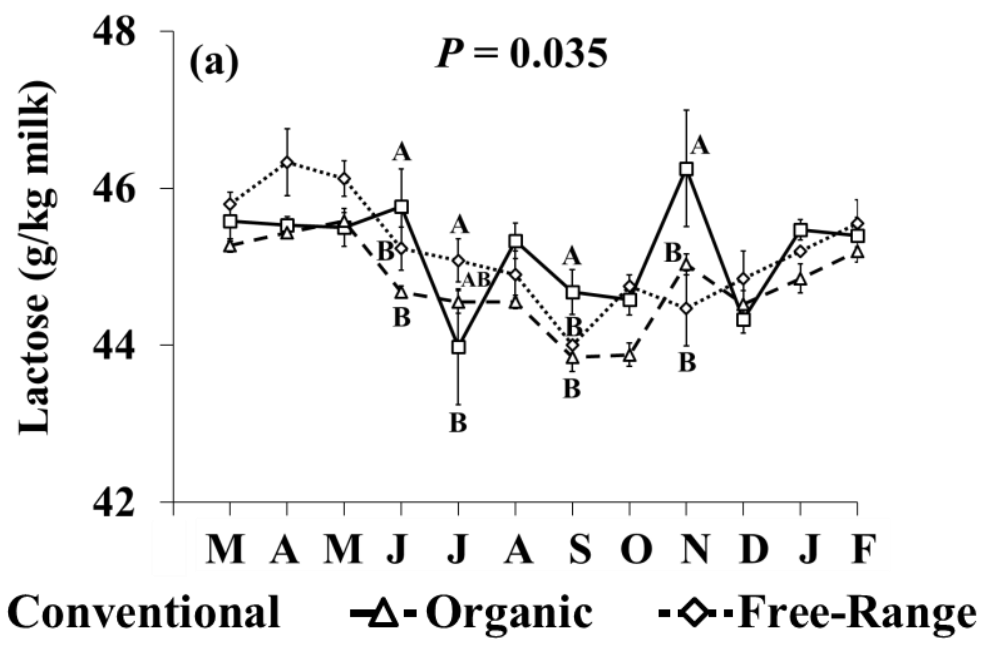

Figure A1. Interaction means \pm SE (error bars) for the effects of production system (conventional, organic, free-range) and month (in order of appearance from left to right in Axis Y: M, March; A, April; M, May; J, June; J, July; A, August; S, September; O, October; N, November; D, December; J, January; F, February) on the concentrations of lactose of milk collected from retail outlets during the year. $\mathrm{P}$ represents the ANOVA P-value for the interaction. Means for production system and within a month with different upper case letters are significantly different according to Fisher's Least Significant Difference test $(\mathrm{P}<0.05)$. 


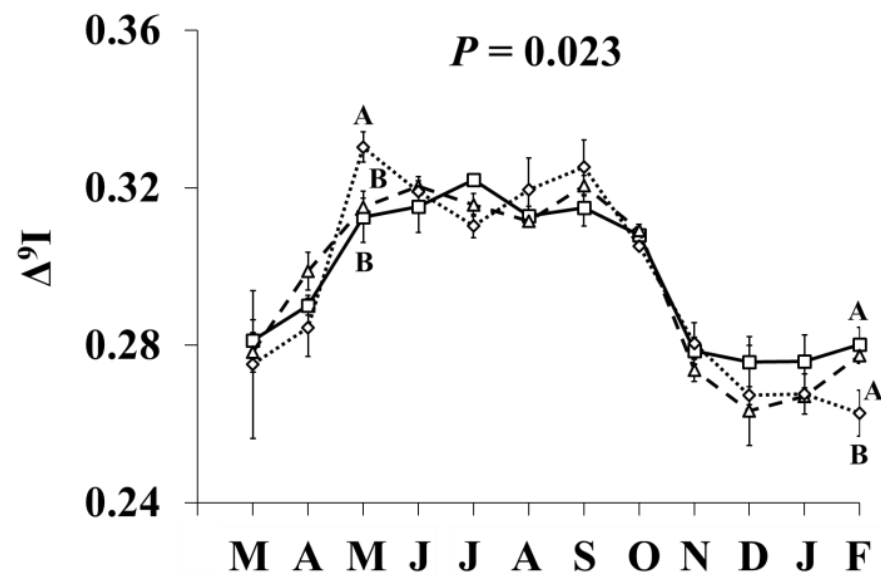

\author{
$-\square-$ Conventional \\ $-\Delta$-Organic \\ $-\diamond$-Free-Range
}
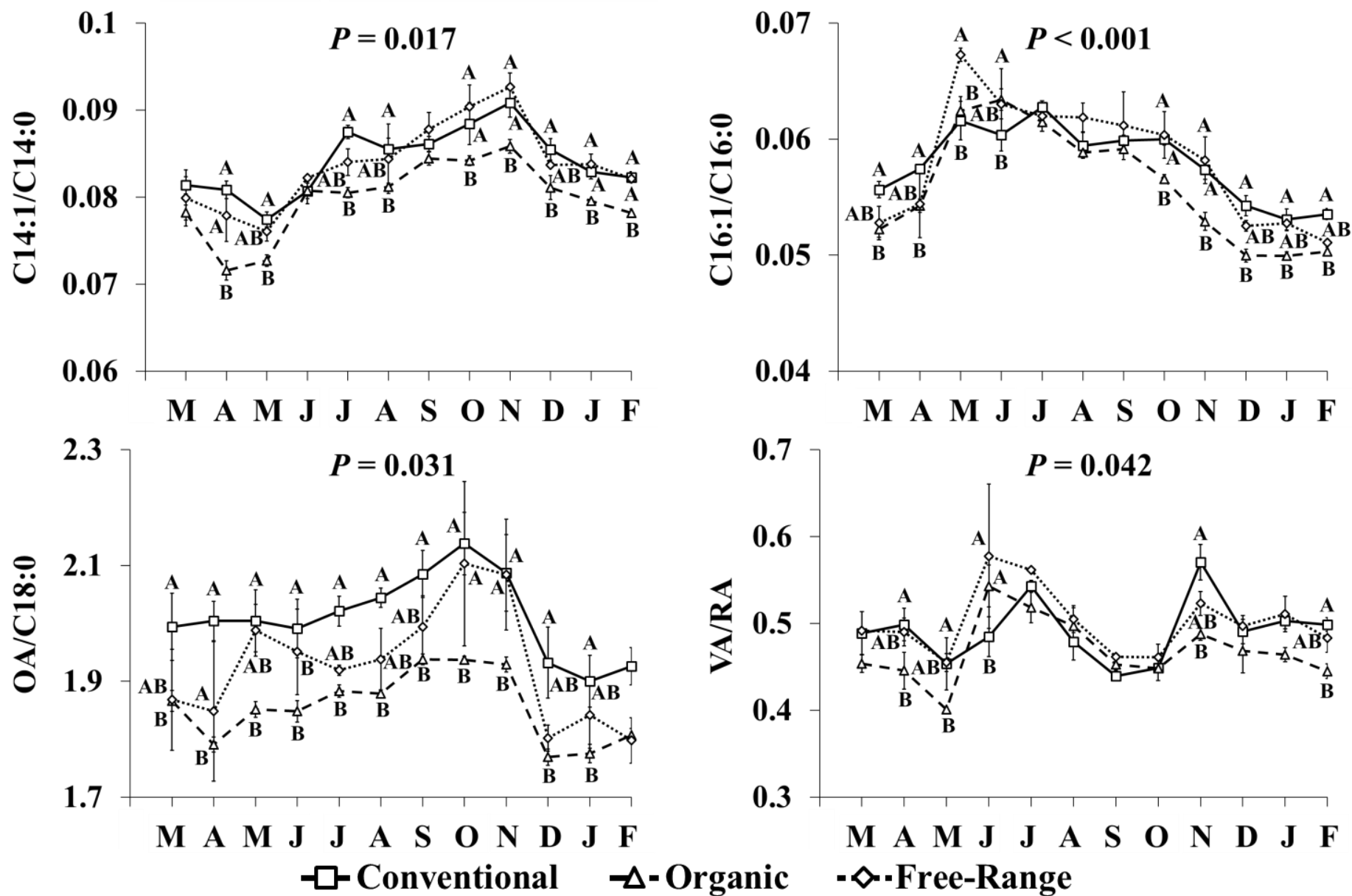

Figure A2. Interaction means $\pm \mathrm{SE}$ (error bars) for the effects of production system (conventional, organic, free-range) and month (in order of appearance from left to right in Axis Y: M, March; A, April; M, May; J, June; J, July; A, August; S, September; O, October; N, November; D, December; J, January; F, February) on the $\Delta^{9}$-desaturase activity indices $\left(\Delta^{9} \mathrm{I}\right.$ as proposed by Kay et al. (2004), and ratios of C14:1/C14:0, C16:1/C16:0, oleic acid (OA)/C18:0 and vaccenic acid (VA)/rumenic acid (RA)) of milk collected from retail outlets during the year. P represents the ANOVA P-value for the interaction. Means for production system and within a month with different upper case letters are significantly different according to Fisher's Least Significant Difference test $(\mathrm{P}<0.05)$.

710 
Table A1

Means (and average SE) and ANOVA P-values for the effect of production system (conventional, CON; organic, ORG; free-range, FR) on the fatty acid profile $(\mathrm{g} / \mathrm{kg}$ total fatty acids) of milk collected from retail outlets during the year

\begin{tabular}{|c|c|c|c|c|c|}
\hline \multirow[b]{2}{*}{ Parameters assessed } & \multicolumn{3}{|c|}{ Production System } & \multirow[b]{2}{*}{ SE } & \multirow[b]{2}{*}{$\begin{array}{l}\text { ANOVA } \\
\text { P-values }\end{array}$} \\
\hline & $\begin{array}{l}\mathrm{CON} \\
\mathrm{n}=48\end{array}$ & $\begin{array}{l}\text { ORG } \\
n=48\end{array}$ & $\begin{array}{c}\mathrm{FR} \\
\mathrm{n}=24^{a}\end{array}$ & & \\
\hline$\overline{\mathrm{C} 4: 0}$ & 20.7 & 21.2 & 20.9 & $\overline{0.54}$ & $t$ \\
\hline C5:0 & 0.207 & 0.230 & 0.194 & 0.0189 & ns \\
\hline C6:0 & $15.3^{\mathrm{B}}$ & $15.9^{\mathrm{A}}$ & $15.5^{\mathrm{AB}}$ & 0.38 & $*$ \\
\hline C7:0 & $0.218^{\mathrm{A}}$ & $0.174^{\mathrm{B}}$ & $0.206^{\mathrm{AB}}$ & 0.0123 & $*$ \\
\hline $\mathrm{C} 8: 0$ & 10.0 & 10.3 & 10.1 & 0.23 & ns \\
\hline C9:0 & 0.288 & 0.244 & 0.270 & 0.0122 & ns \\
\hline C10:0 & 25.1 & 25.7 & 25.5 & 0.55 & ns \\
\hline c9 C10:1 & 2.44 & 2.55 & 2.52 & 0.045 & ns \\
\hline C11:0 & 0.547 & 0.459 & 0.509 & 0.0228 & ns \\
\hline C12:0 & 33.4 & 32.4 & 34.8 & 0.60 & ns \\
\hline $\mathrm{C} 13: 0$ iso & $0.271^{\mathrm{B}}$ & $0.334^{\mathrm{A}}$ & $0.291^{\mathrm{B}}$ & 0.0104 & $* *$ \\
\hline $\mathrm{C} 13: 0$ anteiso & 0.145 & 0.110 & 0.116 & 0.0087 & $\dagger$ \\
\hline c9 C12:1 & 0.830 & 0.799 & 0.861 & 0.0173 & ns \\
\hline C13:0 & 0.908 & 0.870 & 0.848 & 0.0265 & ns \\
\hline $\mathrm{C} 14: 0$ iso & $0.812^{\mathrm{B}}$ & $1.037^{\mathrm{A}}$ & $0.836^{\mathrm{B}}$ & 0.0180 & $* * *$ \\
\hline C14:0 & 111 & 114 & 114 & 1.1 & ns \\
\hline t9 C14:1 & $2.16^{\mathrm{C}}$ & $2.56^{\mathrm{A}}$ & $2.37^{\mathrm{B}}$ & 0.042 & $* * *$ \\
\hline $\mathrm{C} 15: 0$ anteiso & $4.23^{\mathrm{B}}$ & $4.74^{\mathrm{A}}$ & $4.65^{\mathrm{A}}$ & 0.098 & $* *$ \\
\hline c9 C14:1 & 9.31 & 9.09 & 9.56 & 0.138 & $\mathrm{~ns}$ \\
\hline C15:0 & $10.3^{\mathrm{B}}$ & $11.1^{\mathrm{A}}$ & $10.6^{\mathrm{B}}$ & 0.13 & $* *$ \\
\hline $\mathrm{C} 16: 0$ iso & $1.99^{\mathrm{B}}$ & $2.26^{\mathrm{A}}$ & $1.97^{\mathrm{B}}$ & 0.028 & $* * *$ \\
\hline C16:0 & $331^{\mathrm{A}}$ & $314^{\mathrm{B}}$ & $325^{\mathrm{A}}$ & 3.7 & $* * *$ \\
\hline $\mathrm{t} 6+\mathrm{t} 7+\mathrm{t} 8 \mathrm{C} 16: 1$ & $0.316^{\mathrm{A}}$ & $0.293^{\mathrm{B}}$ & $0.290^{\mathrm{B}}$ & 0.0071 & $*$ \\
\hline t9 C16:1 & 0.092 & 0.081 & 0.083 & 0.0030 & ns \\
\hline $\mathrm{C} 17: 0$ iso & $3.84^{\mathrm{B}}$ & $4.28^{\mathrm{A}}$ & $4.09^{\mathrm{AB}}$ & 0.110 & $*$ \\
\hline $\mathrm{t} 11+\mathrm{t} 12+\mathrm{t} 13 \mathrm{C} 16: 1$ & 1.96 & 1.87 & 1.92 & 0.047 & $\mathrm{~ns}$ \\
\hline c9 $\mathrm{C} 16: 1+\mathrm{C} 17$ anteiso & $19.1^{\mathrm{A}}$ & $17.5^{\mathrm{B}}$ & $18.8^{\mathrm{A}}$ & 0.14 & $* * *$ \\
\hline c11 C16:1 & 1.43 & 1.48 & 1.89 & 0.053 & $\dagger$ \\
\hline c13 C16:1 & 1.40 & 1.34 & 1.40 & 0.052 & ns \\
\hline $\mathrm{C} 17: 0$ & $4.87^{\mathrm{B}}$ & $5.69^{\mathrm{A}}$ & $5.02^{\mathrm{B}}$ & 0.070 & $* * *$ \\
\hline $\mathrm{t} 10 \mathrm{c} 17: 1$ & $0.501^{\mathrm{B}}$ & $0.551^{\mathrm{A}}$ & $0.477^{\mathrm{C}}$ & 0.0138 & $* * *$ \\
\hline $\mathrm{C} 18: 0$ iso & 0.571 & 0.636 & 0.706 & 0.0195 & ns \\
\hline c9 C17:1 & $2.11^{\mathrm{B}}$ & $2.27^{\mathrm{A}}$ & $2.15^{\mathrm{AB}}$ & 0.035 & $*$ \\
\hline C18:0 & 100 & 106 & 103 & 1.4 & ns \\
\hline t4 C18:1 & $0.158^{\mathrm{A}}$ & $0.128^{\mathrm{B}}$ & $0.120^{\mathrm{B}}$ & 0.0049 & $* *$ \\
\hline t5 C18:1 & $0.111^{\mathrm{A}}$ & $0.088^{\mathrm{B}}$ & $0.092^{\mathrm{AB}}$ & 0.0039 & $*$ \\
\hline $\mathrm{t} 6+\mathrm{t} 7+\mathrm{t} 8 \mathrm{C} 18: 1$ & 2.76 & 2.55 & 2.40 & 0.048 & $\dagger$ \\
\hline t9 C18:1 & $1.93^{\mathrm{A}}$ & $1.66^{\mathrm{B}}$ & $1.72^{\mathrm{AB}}$ & 0.045 & * \\
\hline $\mathrm{t} 10 \mathrm{C} 18: 1$ & 3.70 & 3.49 & 3.40 & 0.241 & $\mathrm{~ns}$ \\
\hline t11 C18:1 & $12.2^{\mathrm{B}}$ & $17.1^{\mathrm{A}}$ & $12.3^{\mathrm{B}}$ & 0.71 & $* * *$ \\
\hline $\mathrm{c} 6+\mathrm{t} 12 \mathrm{C} 18: 1$ & $2.83^{\mathrm{A}}$ & $2.30^{\mathrm{B}}$ & $2.50^{\mathrm{B}}$ & 0.124 & $* *$ \\
\hline c9 C18:1 & 200 & 197 & 199 & 3.0 & ns \\
\hline t15 C18:1 & $2.08^{\mathrm{A}}$ & $1.89^{\mathrm{B}}$ & $1.97^{\mathrm{AB}}$ & 0.146 & $*$ \\
\hline c11 C18:1 & $5.89^{\mathrm{A}}$ & $4.61^{\mathrm{B}}$ & $4.90^{\mathrm{B}}$ & 0.099 & $*$ \\
\hline c12 C18:1 & 2.24 & 1.94 & 1.90 & 0.057 & ns \\
\hline c13 C18:1 & $0.913^{\mathrm{A}}$ & $0.819^{\mathrm{B}}$ & $0.864^{\mathrm{AB}}$ & 0.0160 & $*$ \\
\hline $\mathrm{t} 16+\mathrm{c} 14 \mathrm{C} 18: 1$ & 3.25 & 3.29 & 3.27 & 0.049 & ns \\
\hline c15 C18:1 + C19:0 & 1.27 & 1.35 & 1.34 & 0.059 & $\dagger$ \\
\hline t11t15 C18:2 & $0.269^{\mathrm{B}}$ & $0.444^{\mathrm{A}}$ & $0.314^{\mathrm{B}}$ & 0.0278 & $*$ \\
\hline t9t12 C18:2 & 0.071 & 0.072 & 0.058 & 0.0072 & ns \\
\hline
\end{tabular}




\begin{tabular}{|c|c|c|c|c|c|}
\hline c9t13 C18:2 & 2.10 & 2.00 & 1.99 & 0.052 & ns \\
\hline c10t14 C18:2 & 1.10 & 1.08 & 1.00 & 0.024 & ns \\
\hline c9t14 C18:2 & $1.25^{\mathrm{A}}$ & $1.14^{\mathrm{B}}$ & $1.18^{\mathrm{AB}}$ & 0.022 & $*$ \\
\hline c9t12 C18:2 & $0.620^{\mathrm{A}}$ & $0.596^{\mathrm{B}}$ & $0.614^{\mathrm{AB}}$ & 0.0087 & $*$ \\
\hline c16 C18:1 & 0.336 & 0.371 & 0.320 & 0.0166 & ns \\
\hline t11c15 C18:2 & $1.50^{\mathrm{B}}$ & $2.23^{\mathrm{A}}$ & $1.71^{\mathrm{B}}$ & 0.101 & $* *$ \\
\hline t9c12 C18:2 & $0.194^{\mathrm{A}}$ & $0.118^{\mathrm{C}}$ & $0.157^{\mathrm{B}}$ & 0.0125 & $* * *$ \\
\hline c9c12 C18:2 & 17.1 & 16.6 & 15.3 & 0.28 & ns \\
\hline t12c15 C18:2 + c9 C19:1 & 0.430 & 0.480 & 0.480 & 0.0461 & ns \\
\hline C20:0 & $1.40^{\mathrm{B}}$ & $1.60^{\mathrm{A}}$ & $1.39^{\mathrm{B}}$ & 0.025 & $* *$ \\
\hline c6c9c12 C18:3 & 0.258 & 0.229 & 0.226 & 0.0069 & ns \\
\hline c8 C20:1 & $1.02^{\mathrm{B}}$ & $1.13^{\mathrm{A}}$ & $1.01^{\mathrm{B}}$ & 0.014 & $* *$ \\
\hline c11 C20:1 & 0.393 & 0.346 & 0.347 & 0.0295 & + \\
\hline c9c12c15 C18:3 & $4.39^{\mathrm{B}}$ & $6.71^{\mathrm{A}}$ & $4.76^{\mathrm{B}}$ & 0.141 & $* * *$ \\
\hline c9t11 C18:2 & $5.91^{\mathrm{B}}$ & $7.95^{\mathrm{A}}$ & $6.06^{\mathrm{B}}$ & 0.315 & $* * *$ \\
\hline Unknown C18:2 conjugated & $0.286^{\mathrm{B}}$ & $0.344^{\mathrm{A}}$ & $0.277^{\mathrm{B}}$ & 0.0172 & $*$ \\
\hline Unknown C18:2 conjugated & $0.265^{\mathrm{B}}$ & $0.413^{\mathrm{A}}$ & $0.288^{\mathrm{B}}$ & 0.0134 & $* * *$ \\
\hline c11c14 C20:2 & $0.196^{\mathrm{B}}$ & $0.220^{\mathrm{A}}$ & $0.196^{\mathrm{B}}$ & 0.0156 & $*$ \\
\hline $\mathrm{C} 22: 0$ & $0.556^{\mathrm{B}}$ & $0.735^{\mathrm{A}}$ & $0.578^{\mathrm{B}}$ & 0.0118 & $* * *$ \\
\hline c8c11c14 C20:3 & 0.809 & 0.704 & 0.713 & 0.0105 & + \\
\hline c13 C22:1 & 0.160 & 0.182 & 0.093 & 0.0129 & ns \\
\hline c11c14c17 C20:3 & $0.105^{\mathrm{B}}$ & $0.186^{\mathrm{A}}$ & $0.102^{\mathrm{B}}$ & 0.0102 & $* * *$ \\
\hline c5c8c11c14 C20:4 & 1.06 & 0.95 & 0.94 & 0.016 & $\dagger$ \\
\hline c13c16 C22:2 & 0.397 & 0.452 & 0.495 & 0.0138 & ns \\
\hline c5c8c11c14c17 C20:5 & $0.484^{\mathrm{B}}$ & $0.674^{\mathrm{A}}$ & $0.551^{\mathrm{B}}$ & 0.0143 & $* * *$ \\
\hline $\mathrm{C} 24: 0$ & $0.345^{\mathrm{B}}$ & $0.457^{\mathrm{A}}$ & $0.362^{\mathrm{B}}$ & 0.0063 & $* * *$ \\
\hline c13c16c19 C22:3 & 0.104 & 0.114 & 0.096 & 0.0070 & $\dagger$ \\
\hline c7c10c13c16 C22:4 & $0.170^{\mathrm{A}}$ & $0.132^{\mathrm{B}}$ & $0.114^{\mathrm{B}}$ & 0.0113 & $*$ \\
\hline c7c10c13c16c19 C22:5 & $0.795^{\mathrm{B}}$ & $1.024^{\mathrm{A}}$ & $0.834^{\mathrm{B}}$ & 0.0161 & $* * *$ \\
\hline $\mathrm{c} 4 \mathrm{c} 7 \mathrm{c} 10 \mathrm{c} 13 \mathrm{c} 16 \mathrm{c} 19 \mathrm{C} 22: 6$ & 0.067 & 0.078 & 0.060 & 0.0051 & ns \\
\hline \multicolumn{6}{|c|}{$\begin{array}{l}{ }^{a} \text { In September, there was a missing sample of free-range milk in the analysis of basic } \\
\text { composition and the mean on this set of parameters was calculated from } 23 \text { samples } \\
{ }^{b} \text { Significances were declared at } * * *, P<0.001 ; * *, P<0.01 ; *, P<0.05 ;+, 0.05<\mathrm{P}<0.10 \\
\text { (trend); ns, } \mathrm{P}>0.10 \text { (non-significant). Means for production system within a row with } \\
\text { different upper case letters are significantly different according to Fisher's Least Significant } \\
\text { Difference test }(\mathrm{P}<0.05)\end{array}$} \\
\hline
\end{tabular}


Table A2

Means (and average SE) and ANOVA P-values for the effect of month on the fatty acid profile ( $\mathrm{g} / \mathrm{kg}$ total fatty acids) of milk collected from retail outlets during the year

\begin{tabular}{|c|c|c|c|c|c|c|c|c|c|c|c|c|c|c|}
\hline \multirow[b]{2}{*}{ Parameters assessed } & & \multirow[b]{2}{*}{ SE } & \multirow[b]{2}{*}{$\begin{array}{l}\text { ANOVA } \\
\text { P-values }\end{array}$} \\
\hline & $\begin{array}{c}\text { March } \\
\mathrm{n}=10\end{array}$ & $\begin{array}{l}\text { April } \\
\mathrm{n}=10\end{array}$ & $\begin{array}{l}\text { May } \\
\mathrm{n}=10\end{array}$ & $\begin{array}{l}\text { June } \\
\mathrm{n}=10\end{array}$ & $\begin{array}{c}\text { July } \\
\mathrm{n}=10\end{array}$ & $\begin{array}{c}\text { August } \\
\mathrm{n}=10\end{array}$ & $\begin{array}{c}\text { September } \\
\mathrm{n}=10^{a}\end{array}$ & $\begin{array}{c}\text { October } \\
n=10\end{array}$ & $\begin{array}{c}\text { November I } \\
n=10\end{array}$ & $\begin{array}{c}\text { December } \\
n=10\end{array}$ & $\begin{array}{c}\text { January } \\
n=10\end{array}$ & $\begin{array}{c}\text { February } \\
n=10\end{array}$ & & \\
\hline$\overline{\mathrm{C} 4: 0}$ & $20.8^{\mathrm{D}}$ & $22.4^{\mathrm{BC}}$ & $22.7^{\mathrm{B}}$ & $23.2^{\mathrm{A}}$ & $23.5^{\mathrm{A}}$ & $22.4^{\mathrm{BC}}$ & $14.7^{\mathrm{F}}$ & $14.3^{\mathrm{F}}$ & $18.3^{\mathrm{E}}$ & $23.3^{\mathrm{A}}$ & $23.6^{\mathrm{A}}$ & $22.0^{C}$ & 0.19 & $* * *$ \\
\hline C5:0 & 0.224 & 0.215 & 0.215 & 0.174 & 0.169 & 0.172 & 0.125 & 0.140 & 0.202 & 0.235 & 0.296 & 0.396 & 0.0258 & ns \\
\hline C6:0 & $16.5^{\mathrm{BC}}$ & $16.7^{\mathrm{B}}$ & $16.5^{\mathrm{C}}$ & $16.6^{\mathrm{BC}}$ & $16.5^{\mathrm{C}}$ & $16.1^{\mathrm{D}}$ & $10.8^{\mathrm{F}}$ & $10.9^{\mathrm{F}}$ & $15.1^{\mathrm{E}}$ & $17.3^{\mathrm{A}}$ & $17.4^{\mathrm{A}}$ & $16.7^{\mathrm{B}}$ & 0.14 & $* * *$ \\
\hline C7:0 & $0.231^{\mathrm{BC}}$ & $0.223^{\mathrm{BC}}$ & $0.219^{\mathrm{C}}$ & $0.163^{\mathrm{D}}$ & $0.151^{\mathrm{DE}}$ & $0.155^{\mathrm{D}}$ & $0.115^{\mathrm{E}}$ & $0.141^{\mathrm{DE}}$ & $0.208^{\mathrm{C}}$ & $0.245^{\mathrm{BC}}$ & $0.274^{\mathrm{A}}$ & $0.253^{\mathrm{B}}$ & 0.0136 & $* * *$ \\
\hline C8:0 & $10.9^{\mathrm{AB}}$ & $11.0^{\mathrm{AB}}$ & $11.0^{\mathrm{AB}}$ & $10.6^{\mathrm{CD}}$ & $10.4^{\mathrm{DE}}$ & $10.2^{\mathrm{E}}$ & $7.1^{\mathrm{G}}$ & $7.4^{\mathrm{F}}$ & $10.4^{\mathrm{DE}}$ & $11.1^{\mathrm{A}}$ & $11.0^{\mathrm{A}}$ & $10.7^{\mathrm{BC}}$ & 0.13 & $* * *$ \\
\hline C9:0 & $0.317^{\mathrm{AB}}$ & $0.303^{\mathrm{B}}$ & $0.311^{\mathrm{B}}$ & $0.217^{\mathrm{C}}$ & $0.210^{\mathrm{C}}$ & $0.215^{\mathrm{C}}$ & $0.173^{\mathrm{D}}$ & $0.208^{\mathrm{C}}$ & $0.308^{\mathrm{AB}}$ & $0.318^{\mathrm{AB}}$ & $0.326^{\mathrm{A}}$ & $0.297^{\mathrm{B}}$ & 0.0138 & $* * *$ \\
\hline C10:0 & $27.6^{\mathrm{A}}$ & $27.5^{\mathrm{AB}}$ & $27.5^{\mathrm{AB}}$ & $25.3^{\mathrm{C}}$ & $24.9^{\mathrm{C}}$ & $24.5^{\mathrm{C}}$ & $18.9^{\mathrm{E}}$ & $20.3^{\mathrm{D}}$ & $27.7^{\mathrm{A}}$ & $27.3^{\mathrm{AB}}$ & $27.2^{\mathrm{AB}}$ & $26.4^{\mathrm{B}}$ & 0.44 & $* * *$ \\
\hline c9 C10:1 & $2.62^{\mathrm{BCD}}$ & $2.50^{\mathrm{EF}}$ & $2.43^{\mathrm{G}}$ & $2.46^{\mathrm{FG}}$ & $2.56^{\mathrm{DEF}}$ & $2.54^{\mathrm{DEF}}$ & $1.99^{\mathrm{I}}$ & $2.10^{\mathrm{H}}$ & $2.85^{\mathrm{A}}$ & $2.69^{\mathrm{B}}$ & $2.65^{\mathrm{BC}}$ & $2.58^{\mathrm{CDE}}$ & 0.041 & $* * *$ \\
\hline C11:0 & $0.587^{\mathrm{A}}$ & $0.552^{\mathrm{A}}$ & $0.584^{\mathrm{A}}$ & $0.394^{\mathrm{BC}}$ & $0.381^{\mathrm{C}}$ & $0.391^{\mathrm{BC}}$ & $0.348^{\mathrm{C}}$ & $0.429^{\mathrm{B}}$ & $0.607^{\mathrm{A}}$ & $0.610^{\mathrm{A}}$ & $0.594^{\mathrm{A}}$ & $0.573^{\mathrm{A}}$ & 0.0267 & $* * *$ \\
\hline C12:0 & $35.9^{\mathrm{B}}$ & $34.8^{\mathrm{BCD}}$ & $34.2^{\mathrm{D}}$ & $31.1^{\mathrm{EF}}$ & $31.4^{\mathrm{E}}$ & $31.1^{\mathrm{EF}}$ & $27.5^{\mathrm{G}}$ & $29.9^{\mathrm{F}}$ & $37.7^{\mathrm{A}}$ & $35.7^{\mathrm{BC}}$ & $35.6^{\mathrm{BC}}$ & $34.3^{\mathrm{CD}}$ & 0.62 & $* * *$ \\
\hline $\mathrm{C} 13: 0$ iso & $0.280^{\mathrm{E}}$ & $0.280^{\mathrm{E}}$ & $0.306^{\mathrm{C}}$ & $0.377^{\mathrm{A}}$ & $0.380^{\mathrm{A}}$ & $0.380^{\mathrm{A}}$ & $0.332^{\mathrm{B}}$ & $0.300^{\mathrm{CD}}$ & $0.288^{\mathrm{DE}}$ & $0.221^{\mathrm{F}}$ & $0.229^{\mathrm{F}}$ & $0.227^{\mathrm{F}}$ & 0.0125 & $* * *$ \\
\hline $\mathrm{C} 13: 0$ anteiso & $0.113^{\mathrm{B}}$ & $0.105^{\mathrm{B}}$ & $0.098^{\mathrm{B}}$ & $0.111^{\mathrm{B}}$ & $0.118^{\mathrm{B}}$ & $0.291^{\mathrm{A}}$ & $0.096^{\mathrm{B}}$ & $0.098^{\mathrm{B}}$ & $0.116^{\mathrm{B}}$ & $0.115^{\mathrm{B}}$ & $0.120^{\mathrm{B}}$ & $0.123^{\mathrm{B}}$ & 0.0105 & $* * *$ \\
\hline c9 C12:1 & $0.868^{\mathrm{B}}$ & $0.812^{\mathrm{CD}}$ & $0.812^{\mathrm{CDE}}$ & $0.759^{\mathrm{E}}$ & $0.796^{\mathrm{CDE}}$ & $0.787^{\mathrm{CDE}}$ & $0.697^{\mathrm{F}}$ & $0.773^{\mathrm{DE}}$ & $0.995^{\mathrm{A}}$ & $0.881^{\mathrm{B}}$ & $0.876^{\mathrm{B}}$ & $0.827^{\mathrm{BC}}$ & 0.0210 & $* * *$ \\
\hline C13:0 & $0.976^{\mathrm{ABC}}$ & $0.927^{\mathrm{CD}}$ & $0.935^{\mathrm{DE}}$ & $0.752^{\mathrm{F}}$ & $0.745^{\mathrm{F}}$ & $0.768^{\mathrm{F}}$ & $0.713^{\mathrm{F}}$ & $0.824^{\mathrm{E}}$ & $1.026^{\mathrm{A}}$ & $0.970^{\mathrm{ABCD}}$ & $1.001^{\mathrm{AB}}$ & $0.933^{\mathrm{BCD}}$ & 0.0316 & $*$ \\
\hline $\mathrm{C} 14: 0$ iso & $0.837^{\mathrm{DE}}$ & $0.818^{\mathrm{E}}$ & $0.846^{\mathrm{CDE}}$ & $1.008^{\mathrm{A}}$ & $1.048^{\mathrm{A}}$ & $1.004^{\mathrm{A}}$ & $0.907^{\mathrm{B}}$ & $0.882^{\mathrm{BCD}}$ & $0.913^{\mathrm{BC}}$ & $0.864^{\mathrm{CDE}}$ & $0.863^{\mathrm{CDE}}$ & $0.891^{\mathrm{BCDE}}$ & 0.0416 & $* * *$ \\
\hline $\mathrm{C} 14: 0$ & $116^{\mathrm{B}}$ & $113^{\mathrm{C}}$ & $109^{\mathrm{DE}}$ & $107^{\mathrm{E}}$ & $109^{\mathrm{D}}$ & $109^{\mathrm{DE}}$ & $105^{\mathrm{F}}$ & $110^{\mathrm{D}}$ & $123^{\mathrm{A}}$ & $117^{\mathrm{B}}$ & $117^{\mathrm{B}}$ & $116^{\mathrm{B}}$ & 1.1 & $* *$ \\
\hline t9 C14:1 & $2.23^{\mathrm{DEF}}$ & $2.23^{\mathrm{DE}}$ & $2.40^{\mathrm{BC}}$ & $2.65^{\mathrm{A}}$ & $2.74^{\mathrm{A}}$ & $2.63^{\mathrm{A}}$ & $2.41^{\mathrm{B}}$ & $2.31^{\mathrm{CD}}$ & $2.27^{\mathrm{DE}}$ & $2.10^{\mathrm{F}}$ & $2.17^{\mathrm{EF}}$ & $2.21^{\mathrm{DEF}}$ & 0.072 & $* * *$ \\
\hline $\mathrm{C} 15: 0$ anteiso & $4.26^{\mathrm{BCD}}$ & $4.36^{\mathrm{BCD}}$ & $5.07^{\mathrm{A}}$ & $5.14^{\mathrm{A}}$ & $5.23^{\mathrm{A}}$ & $4.50^{\mathrm{B}}$ & $4.52^{\mathrm{BC}}$ & $4.48^{\mathrm{BC}}$ & $4.34^{\mathrm{BCD}}$ & $4.00^{\mathrm{D}}$ & $4.15^{\mathrm{CD}}$ & $4.18^{\mathrm{BCD}}$ & 0.120 & $* * *$ \\
\hline c9 C14:1 & $9.29^{\mathrm{DE}}$ & $8.64^{\mathrm{F}}$ & $8.17^{\mathrm{G}}$ & $8.66^{\mathrm{F}}$ & $9.18^{\mathrm{DE}}$ & $9.08^{\mathrm{E}}$ & $8.99^{\mathrm{E}}$ & $9.61^{\mathrm{B}}$ & $10.99^{\mathrm{A}}$ & $9.73^{\mathrm{B}}$ & $9.57^{\mathrm{BC}}$ & $9.32^{\mathrm{CD}}$ & 0.136 & $* * *$ \\
\hline $\mathrm{C} 15: 0$ & $10.8^{\mathrm{CD}}$ & $10.1^{\mathrm{E}}$ & $10.0^{\mathrm{EF}}$ & $9.8^{\mathrm{F}}$ & $10.1^{\mathrm{EF}}$ & $10.1^{\mathrm{E}}$ & $10.6^{\mathrm{E}}$ & $11.0^{\mathrm{BC}}$ & $11.9^{\mathrm{A}}$ & $11.4^{\mathrm{B}}$ & $11.4^{\mathrm{B}}$ & $11.1^{\mathrm{B}}$ & 0.17 & $* * *$ \\
\hline $\mathrm{C} 16: 0$ iso & $2.00^{\mathrm{EFG}}$ & $2.02^{\mathrm{EFG}}$ & $2.04^{\mathrm{DE}}$ & $2.26^{\mathrm{AB}}$ & $2.32^{\mathrm{A}}$ & $2.23^{\mathrm{B}}$ & $2.11^{\mathrm{E}}$ & $2.10^{\mathrm{CD}}$ & $2.02^{\mathrm{EFG}}$ & $1.98^{\mathrm{FG}}$ & $1.96^{\mathrm{G}}$ & $2.06^{\mathrm{EF}}$ & 0.056 & $* * *$ \\
\hline $\mathrm{C} 16: 0$ & $341^{\mathrm{A}}$ & $321^{\mathrm{C}}$ & $289^{\mathrm{E}}$ & $297^{\mathrm{D}}$ & $299^{\mathrm{D}}$ & $305^{\mathrm{D}}$ & $319^{\mathrm{C}}$ & $329^{\mathrm{B}}$ & $346^{\mathrm{A}}$ & $348^{\mathrm{A}}$ & $344^{\mathrm{A}}$ & $342^{\mathrm{A}}$ & 3.6 & $* * *$ \\
\hline $\mathrm{t} 6+\mathrm{t} 7+\mathrm{t} 8 \mathrm{C} 16: 1$ & $0.309^{\mathrm{CDE}}$ & $0.303^{\mathrm{DE}}$ & $0.318^{\mathrm{BCD}}$ & $0.322^{\mathrm{BC}}$ & $0.333^{\mathrm{AB}}$ & $0.339^{\mathrm{A}}$ & $0.337^{\mathrm{A}}$ & $0.341^{\mathrm{A}}$ & $0.300^{\mathrm{E}}$ & $0.233^{\mathrm{F}}$ & $0.239^{\mathrm{F}}$ & $0.245^{\mathrm{F}}$ & 0.0068 & $* * *$ \\
\hline t9 C16:1 & $0.077^{\mathrm{C}}$ & $0.089^{\mathrm{BC}}$ & $0.105^{\mathrm{A}}$ & $0.094^{\mathrm{AB}}$ & $0.086^{\mathrm{BC}}$ & $0.098^{\mathrm{AB}}$ & $0.081^{\mathrm{C}}$ & $0.077^{\mathrm{CD}}$ & $0.096^{\mathrm{AB}}$ & $0.063^{\mathrm{D}}$ & $0.077^{\mathrm{C}}$ & $0.089^{\mathrm{BC}}$ & 0.0050 & $* * *$ \\
\hline $\mathrm{C} 17: 0$ iso & $3.50^{\mathrm{F}}$ & $3.76^{\mathrm{E}}$ & $4.78^{\mathrm{AB}}$ & $4.82^{\mathrm{AB}}$ & $4.91^{\mathrm{A}}$ & $4.65^{\mathrm{BC}}$ & $4.49^{\mathrm{C}}$ & $4.18^{\mathrm{D}}$ & $3.52^{\mathrm{F}}$ & $3.34^{\mathrm{F}}$ & $3.37^{\mathrm{F}}$ & $3.46^{\mathrm{F}}$ & 0.095 & $* * *$ \\
\hline $\mathrm{t} 11+\mathrm{t} 12+\mathrm{t} 13 \mathrm{C} 16: 1$ & $1.72^{\mathrm{F}}$ & $1.87^{\mathrm{E}}$ & $2.32^{\mathrm{A}}$ & $2.18^{\mathrm{BC}}$ & $2.19^{\mathrm{BC}}$ & $2.18^{\mathrm{B}}$ & $2.09^{\mathrm{C}}$ & $1.97^{\mathrm{D}}$ & $1.72^{\mathrm{F}}$ & $1.56^{\mathrm{G}}$ & $1.58^{\mathrm{G}}$ & $1.61^{\mathrm{G}}$ & 0.037 & $* * *$ \\
\hline c9 $\mathrm{C} 16: 1+\mathrm{C} 17$ anteiso & $18.3^{\mathrm{CDE}}$ & $17.9^{\mathrm{EFG}}$ & $18.2^{\mathrm{DC}}$ & $18.4^{\mathrm{DC}}$ & $18.6^{\mathrm{C}}$ & $18.2^{\mathrm{CDEF}}$ & $19.1^{\mathrm{B}}$ & $19.3^{\mathrm{A}}$ & $19.3^{\mathrm{AB}}$ & $18.1^{\mathrm{DEF}}$ & $17.8^{\mathrm{FG}}$ & $17.7^{\mathrm{G}}$ & 0.31 & $* * *$ \\
\hline c11 C16:1 & $1.66^{\mathrm{BC}}$ & $1.71^{\mathrm{AB}}$ & $1.66^{\mathrm{BC}}$ & $1.42^{\mathrm{EF}}$ & $1.54^{\mathrm{DE}}$ & $1.58^{\mathrm{CD}}$ & $1.82^{\mathrm{A}}$ & $1.70^{\mathrm{BC}}$ & $1.56^{\mathrm{CD}}$ & $1.25^{\mathrm{F}}$ & $1.32^{\mathrm{F}}$ & $1.28^{\mathrm{F}}$ & 0.097 & $* * *$ \\
\hline
\end{tabular}




\begin{tabular}{|c|c|c|c|c|c|c|c|c|c|c|c|c|c|c|}
\hline c13 C16:1 & $1.45^{\mathrm{BC}}$ & $1.32^{\mathrm{BC}}$ & $1.30^{\mathrm{BC}}$ & $1.15^{\mathrm{C}}$ & $1.24^{\mathrm{BC}}$ & $1.17^{\mathrm{C}}$ & $1.22^{\mathrm{BC}}$ & $1.39^{\mathrm{BC}}$ & $1.87^{\mathrm{A}}$ & $1.50^{\mathrm{B}}$ & $1.47^{\mathrm{B}}$ & $1.40^{\mathrm{BC}}$ & 0.069 & $* * *$ \\
\hline C17:0 & $5.21^{\mathrm{AB}}$ & $5.17^{\mathrm{AB}}$ & $5.38^{\mathrm{AB}}$ & $5.56^{\mathrm{A}}$ & $5.48^{\mathrm{AB}}$ & $5.36^{\mathrm{AB}}$ & $5.41^{\mathrm{AB}}$ & $5.34^{\mathrm{AB}}$ & $4.57^{\mathrm{C}}$ & $5.07^{\mathrm{BC}}$ & $5.07^{\mathrm{BC}}$ & $5.10^{\mathrm{AB}}$ & 0.160 & $* * *$ \\
\hline $\mathrm{t} 10 \mathrm{c} 17: 1$ & $0.529^{\mathrm{E}}$ & $0.546^{\mathrm{DE}}$ & $0.589^{\mathrm{A}}$ & $0.590^{\mathrm{AB}}$ & $0.582^{\mathrm{ABC}}$ & $0.561^{\mathrm{BCD}}$ & $0.566^{\mathrm{BCD}}$ & $0.561^{\mathrm{CD}}$ & $0.499^{\mathrm{F}}$ & $0.409^{\mathrm{G}}$ & $0.368^{\mathrm{H}}$ & $0.395^{\mathrm{GH}}$ & 0.0126 & $* * *$ \\
\hline $\mathrm{C} 18: 0$ iso & $0.582^{\mathrm{EFG}}$ & $0.609^{\mathrm{CDE}}$ & $0.726^{\mathrm{A}}$ & $0.711^{\mathrm{AB}}$ & $0.753^{\mathrm{A}}$ & $0.658^{\mathrm{BC}}$ & $0.646^{\mathrm{BCD}}$ & $0.608^{\mathrm{DEF}}$ & $0.560^{\mathrm{FG}}$ & $0.549^{\mathrm{FG}}$ & $0.543^{\mathrm{G}}$ & $0.547^{\mathrm{G}}$ & 0.0325 & $* * *$ \\
\hline c9 C17:1 & $2.15^{\mathrm{D}}$ & $2.15^{\mathrm{D}}$ & $2.38^{\mathrm{A}}$ & $2.37^{\mathrm{A}}$ & $2.38^{\mathrm{A}}$ & $2.27^{\mathrm{BC}}$ & $2.35^{\mathrm{AB}}$ & $2.25^{\mathrm{C}}$ & $2.11^{\mathrm{D}}$ & $1.94^{\mathrm{E}}$ & $1.92^{\mathrm{E}}$ & $1.92^{\mathrm{E}}$ & 0.041 & $* * *$ \\
\hline C18:0 & $97^{\mathrm{D}}$ & $104^{\mathrm{C}}$ & $108^{\mathrm{B}}$ & $110^{\mathrm{AB}}$ & $109^{\mathrm{B}}$ & $108^{\mathrm{B}}$ & $111^{\mathrm{A}}$ & $104^{\mathrm{C}}$ & $90^{\mathrm{E}}$ & $97^{\mathrm{D}}$ & $97^{\mathrm{D}}$ & $99^{\mathrm{D}}$ & 1.8 & $* * *$ \\
\hline t4 C18:1 & $0.129^{\mathrm{DEF}}$ & $0.130^{\mathrm{DEF}}$ & $0.141^{\mathrm{BCD}}$ & $0.125^{\mathrm{DEF}}$ & $0.110^{\mathrm{EF}}$ & $0.134^{\mathrm{CDE}}$ & $0.135^{\mathrm{CDE}}$ & $0.149^{\mathrm{BCD}}$ & $0.105^{\mathrm{F}}$ & $0.166^{\mathrm{AB}}$ & $0.157^{\mathrm{ABC}}$ & $0.179^{\mathrm{A}}$ & 0.0099 & $* * *$ \\
\hline t5 C18:1 & $0.102^{\mathrm{CDE}}$ & $0.110^{\mathrm{BCD}}$ & $0.116^{\mathrm{AB}}$ & $0.112^{\mathrm{ABC}}$ & $0.095^{\mathrm{E}}$ & $0.100^{\mathrm{DE}}$ & $0.064^{\mathrm{G}}$ & $0.062^{\mathrm{G}}$ & $0.080^{\mathrm{F}}$ & $0.117^{\mathrm{AB}}$ & $0.095^{\mathrm{E}}$ & $0.122^{\mathrm{A}}$ & 0.0055 & $* * *$ \\
\hline $\mathrm{t} 6+\mathrm{t} 7+\mathrm{t} 8 \mathrm{C} 18: 1$ & $2.42^{\mathrm{D}}$ & $2.65^{\mathrm{BC}}$ & $2.83^{\mathrm{A}}$ & $2.76^{\mathrm{AB}}$ & $2.48^{\mathrm{CD}}$ & $2.65^{\mathrm{B}}$ & $2.86^{\mathrm{A}}$ & $2.92^{\mathrm{A}}$ & $2.46^{\mathrm{CD}}$ & $2.33^{\mathrm{D}}$ & $2.37^{\mathrm{D}}$ & $2.50^{\mathrm{CD}}$ & 0.083 & $* * *$ \\
\hline t9 C18:1 & $1.60^{\mathrm{E}}$ & $1.82^{\mathrm{CDE}}$ & $2.01^{\mathrm{A}}$ & $1.87^{\mathrm{ABC}}$ & $1.80^{\mathrm{BCD}}$ & $1.83^{\mathrm{BCD}}$ & $1.44^{\mathrm{F}}$ & $1.37^{\mathrm{F}}$ & $1.68^{\mathrm{DE}}$ & $1.94^{\mathrm{ABC}}$ & $1.96^{\mathrm{AB}}$ & $2.04^{\mathrm{A}}$ & 0.074 & $* * *$ \\
\hline t10 C18:1 & $2.94^{\mathrm{E}}$ & $4.07^{\mathrm{BC}}$ & $4.10^{\mathrm{B}}$ & $6.03^{\mathrm{A}}$ & $5.29^{\mathrm{A}}$ & $3.88^{\mathrm{BCD}}$ & $1.97^{\mathrm{F}}$ & $1.66^{\mathrm{F}}$ & $3.00^{\mathrm{E}}$ & $3.17^{\mathrm{DE}}$ & $3.31^{\mathrm{CDE}}$ & $3.25^{\mathrm{CDE}}$ & 0.288 & $* * *$ \\
\hline t11 C18:1 & $10.1^{\mathrm{E}}$ & $12.2^{\mathrm{D}}$ & $20.9^{\mathrm{A}}$ & $15.9^{\mathrm{C}}$ & $16.1^{\mathrm{C}}$ & $17.2^{\mathrm{BC}}$ & $18.6^{\mathrm{B}}$ & $17.7^{\mathrm{BC}}$ & $10.9^{\mathrm{DE}}$ & $9.9^{\mathrm{E}}$ & $10.2^{\mathrm{E}}$ & $10.5^{\mathrm{DE}}$ & 1.00 & $* * *$ \\
\hline $\mathrm{c} 6+\mathrm{t} 12 \mathrm{C} 18: 1$ & $2.91^{\mathrm{B}}$ & $3.02^{\mathrm{B}}$ & $2.96^{\mathrm{B}}$ & $3.05^{\mathrm{B}}$ & $2.42^{\mathrm{C}}$ & $2.46^{\mathrm{C}}$ & $1.49^{\mathrm{E}}$ & $1.23^{\mathrm{E}}$ & $1.83^{\mathrm{D}}$ & $2.91^{\mathrm{B}}$ & $3.32^{\mathrm{A}}$ & $3.00^{\mathrm{AB}}$ & 0.134 & $* * *$ \\
\hline c9 C18:1 & $186^{\mathrm{D}}$ & $195^{\mathrm{C}}$ & $209^{\mathrm{B}}$ & $212^{\mathrm{B}}$ & $211^{\mathrm{B}}$ & $211^{\mathrm{B}}$ & $223^{A}$ & $213^{\mathrm{B}}$ & $183^{\mathrm{DE}}$ & $178^{\mathrm{E}}$ & $179^{\mathrm{E}}$ & $184^{\mathrm{DE}}$ & 2.3 & $* * *$ \\
\hline t15 C18:1 & $1.84^{\mathrm{B}}$ & $1.87^{\mathrm{B}}$ & $2.07^{\mathrm{B}}$ & $2.07^{\mathrm{B}}$ & $1.82^{\mathrm{B}}$ & $1.98^{\mathrm{B}}$ & $0.95^{\mathrm{C}}$ & $0.58^{\mathrm{D}}$ & $1.27^{\mathrm{C}}$ & $3.07^{\mathrm{A}}$ & $3.13^{\mathrm{A}}$ & $3.12^{\mathrm{A}}$ & 0.111 & $* * *$ \\
\hline c11 C18:1 & $4.82^{\mathrm{FG}}$ & $5.36^{\mathrm{BCD}}$ & $5.75^{\mathrm{A}}$ & $5.43^{\mathrm{B}}$ & $5.08^{\mathrm{CDEF}}$ & $5.14^{\mathrm{CDEF}}$ & $5.38^{\mathrm{BC}}$ & $5.41^{\mathrm{B}}$ & $4.58^{\mathrm{G}}$ & $4.95^{\mathrm{EF}}$ & $5.03^{\mathrm{DEF}}$ & $5.21^{\mathrm{BCDE}}$ & 0.251 & $* * *$ \\
\hline c12 C18:1 & $2.23^{\mathrm{AB}}$ & $2.27^{\mathrm{AB}}$ & $1.91^{\mathrm{C}}$ & $1.93^{\mathrm{C}}$ & $1.66^{\mathrm{D}}$ & $1.87^{\mathrm{C}}$ & $1.88^{\mathrm{C}}$ & $1.95^{\mathrm{C}}$ & $1.93^{\mathrm{C}}$ & $2.26^{\mathrm{B}}$ & $2.30^{\mathrm{AB}}$ & $2.43^{\mathrm{A}}$ & 0.100 & $* * *$ \\
\hline c13 C18:1 & $0.809^{\mathrm{EF}}$ & $0.902^{\mathrm{BCD}}$ & $1.019^{\mathrm{A}}$ & $0.886^{\mathrm{BC}}$ & $0.824^{\mathrm{DE}}$ & $0.897^{\mathrm{BC}}$ & $0.939^{\mathrm{B}}$ & $0.901^{\mathrm{B}}$ & $0.750^{\mathrm{F}}$ & $0.833^{\mathrm{CDE}}$ & $0.785^{\mathrm{EF}}$ & $0.837^{\mathrm{CDE}}$ & 0.0250 & $* * *$ \\
\hline $\mathrm{t} 16+\mathrm{c} 14 \mathrm{C} 18: 1$ & $3.16^{\mathrm{DE}}$ & $3.51^{\mathrm{B}}$ & $3.72^{\mathrm{A}}$ & $3.44^{\mathrm{BC}}$ & $3.33^{\mathrm{CD}}$ & $3.39^{\mathrm{BC}}$ & $3.52^{\mathrm{B}}$ & $3.28^{\mathrm{D}}$ & $2.85^{\mathrm{G}}$ & $2.93^{\mathrm{FG}}$ & $3.04^{\mathrm{EF}}$ & $3.06^{\mathrm{EF}}$ & 0.049 & $* * *$ \\
\hline c15 C18:1 + C19:0 & $1.43^{\mathrm{B}}$ & $1.50^{\mathrm{AB}}$ & $1.59^{\mathrm{AB}}$ & $1.59^{\mathrm{AB}}$ & $1.58^{\mathrm{AB}}$ & $1.41^{\mathrm{B}}$ & $1.63^{\mathrm{A}}$ & $1.55^{\mathrm{AB}}$ & $1.18^{\mathrm{C}}$ & $0.75^{\mathrm{D}}$ & $0.78^{\mathrm{D}}$ & $0.77^{\mathrm{D}}$ & 0.042 & $* * *$ \\
\hline t11t15 C18:2 & $0.215^{\mathrm{EF}}$ & $0.330^{\mathrm{D}}$ & $0.583^{\mathrm{A}}$ & $0.435^{\mathrm{BC}}$ & $0.479^{\mathrm{BC}}$ & $0.474^{\mathrm{BC}}$ & $0.493^{\mathrm{AB}}$ & $0.418^{\mathrm{C}}$ & $0.242^{\mathrm{DE}}$ & $0.155^{\mathrm{EF}}$ & $0.199^{\mathrm{EF}}$ & $0.150^{\mathrm{F}}$ & 0.0387 & $* * *$ \\
\hline t9t12 C18:2 & $0.042^{\mathrm{E}}$ & $0.073^{\mathrm{BCDE}}$ & $0.110^{\mathrm{AB}}$ & $0.057^{\mathrm{DE}}$ & $0.064^{\mathrm{BCDE}}$ & $0.085^{\mathrm{ABCD}}$ & $0.114^{\mathrm{A}}$ & $0.098^{\mathrm{ABC}}$ & $0.048^{\mathrm{DE}}$ & $0.042^{\mathrm{DE}}$ & $0.060^{\mathrm{CDE}}$ & $0.035^{\mathrm{E}}$ & 0.0124 & $* * *$ \\
\hline c9t13 C18:2 & $1.84^{\mathrm{D}}$ & $2.07^{\mathrm{C}}$ & $2.58^{\mathrm{A}}$ & $2.17^{\mathrm{BC}}$ & $2.16^{\mathrm{BC}}$ & $2.22^{\mathrm{B}}$ & $2.30^{\mathrm{B}}$ & $2.22^{\mathrm{B}}$ & $1.85^{\mathrm{D}}$ & $1.61^{\mathrm{E}}$ & $1.68^{\mathrm{DE}}$ & $1.74^{\mathrm{DE}}$ & 0.052 & $* * *$ \\
\hline c10t14 C18:2 & $1.13^{\mathrm{AB}}$ & $1.18^{\mathrm{A}}$ & $1.14^{\mathrm{ABC}}$ & $1.07^{\mathrm{BCD}}$ & $1.03^{\mathrm{BCD}}$ & $1.04^{\mathrm{D}}$ & $1.04^{\mathrm{D}}$ & $1.12^{\mathrm{AB}}$ & $1.04^{\mathrm{BCD}}$ & $1.01^{\mathrm{D}}$ & $1.03^{\mathrm{D}}$ & $1.03^{\mathrm{CD}}$ & 0.040 & $* *$ \\
\hline c9t14 C18:2 & $1.13^{\mathrm{E}}$ & $1.22^{\mathrm{D}}$ & $1.31^{\mathrm{AB}}$ & $1.25^{\mathrm{BCD}}$ & $1.23^{\mathrm{CD}}$ & $1.27^{\mathrm{BC}}$ & $1.35^{\mathrm{A}}$ & $1.31^{\mathrm{AB}}$ & $1.14^{\mathrm{E}}$ & $0.98^{\mathrm{G}}$ & $1.04^{\mathrm{F}}$ & $1.04^{\mathrm{FG}}$ & 0.026 & $* * *$ \\
\hline c9t12 C18:2 & $0.579^{\mathrm{DEF}}$ & $0.656^{\mathrm{AB}}$ & $0.679^{\mathrm{A}}$ & $0.629^{\mathrm{BC}}$ & $0.590^{\mathrm{DE}}$ & $0.610^{\mathrm{CD}}$ & $0.669^{\mathrm{A}}$ & $0.639^{\mathrm{BC}}$ & $0.555^{\mathrm{F}}$ & $0.551^{\mathrm{F}}$ & $0.569^{\mathrm{EF}}$ & $0.586^{\mathrm{DEF}}$ & 0.0121 & $* * *$ \\
\hline c16 C18:1 & $0.256^{\mathrm{D}}$ & $0.352^{\mathrm{C}}$ & $0.500^{\mathrm{A}}$ & $0.427^{\mathrm{B}}$ & $0.404^{\mathrm{B}}$ & $0.393^{\mathrm{B}}$ & $0.424^{\mathrm{B}}$ & $0.413^{\mathrm{B}}$ & $0.312^{\mathrm{C}}$ & $0.209^{\mathrm{E}}$ & $0.239^{\mathrm{DE}}$ & $0.232^{\mathrm{DE}}$ & 0.0173 & $* * *$ \\
\hline $\mathrm{t} 11 \mathrm{c} 15 \mathrm{C} 18: 2$ & $1.22^{\mathrm{E}}$ & $1.56^{\mathrm{D}}$ & $2.64^{\mathrm{A}}$ & $2.29^{\mathrm{BC}}$ & $2.44^{\mathrm{B}}$ & $2.31^{\mathrm{B}}$ & $2.25^{\mathrm{BC}}$ & $2.09^{\mathrm{C}}$ & $1.44^{\mathrm{DE}}$ & $1.26^{\mathrm{E}}$ & $1.28^{\mathrm{E}}$ & $1.22^{\mathrm{E}}$ & 0.143 & $* * *$ \\
\hline t9c12 C18:2 & $0.224^{\mathrm{A}}$ & $0.250^{\mathrm{A}}$ & $0.140^{\mathrm{BC}}$ & $0.154^{\mathrm{B}}$ & $0.109^{\mathrm{CD}}$ & $0.113^{\mathrm{CD}}$ & $0.170^{\mathrm{B}}$ & $0.225^{\mathrm{A}}$ & $0.239^{\mathrm{A}}$ & $0.080^{\mathrm{D}}$ & $0.095^{\mathrm{D}}$ & $0.073^{\mathrm{D}}$ & 0.0180 & $* * *$ \\
\hline c9c12 C18:2 & $17.4^{\mathrm{AB}}$ & $18.1^{\mathrm{A}}$ & $17.2^{\mathrm{ABC}}$ & $16.8^{\mathrm{BCD}}$ & $15.5^{\mathrm{EF}}$ & $16.4^{\mathrm{CDE}}$ & $16.9^{\mathrm{BC}}$ & $17.2^{\mathrm{ABC}}$ & $15.7^{\mathrm{EF}}$ & $15.6^{\mathrm{F}}$ & $15.5^{\mathrm{F}}$ & $16.1^{\mathrm{DEF}}$ & 0.56 & $* * *$ \\
\hline t12c15 C18:2 + c9 C19:1 & $0.237^{\mathrm{G}}$ & $0.290^{\mathrm{DEF}}$ & $0.350^{\mathrm{C}}$ & $0.339^{\mathrm{CD}}$ & $0.330^{\mathrm{CDE}}$ & $0.275^{\mathrm{EFG}}$ & $0.319^{\mathrm{CDE}}$ & $0.312^{\mathrm{CDE}}$ & $0.253^{\mathrm{FG}}$ & $0.894^{\mathrm{B}}$ & $0.938^{\mathrm{AB}}$ & $0.986^{\mathrm{A}}$ & 0.0220 & $* * *$ \\
\hline C20:0 & $1.54^{\mathrm{B}}$ & $1.44^{\mathrm{CD}}$ & $1.33^{\mathrm{E}}$ & $1.51^{\mathrm{BC}}$ & $1.42^{\mathrm{D}}$ & $1.30^{\mathrm{E}}$ & $1.48^{\mathrm{BCD}}$ & $1.48^{\mathrm{CD}}$ & $1.32^{\mathrm{E}}$ & $1.62^{\mathrm{A}}$ & $1.66^{\mathrm{A}}$ & $1.68^{\mathrm{A}}$ & 0.043 & $* * *$ \\
\hline c6c9c12 C18:3 & $0.221^{\mathrm{BC}}$ & $0.239^{\mathrm{ABC}}$ & $0.306^{\mathrm{A}}$ & $0.244^{\mathrm{ABC}}$ & $0.230^{\mathrm{BC}}$ & $0.223^{\mathrm{BC}}$ & $0.227^{\mathrm{BC}}$ & $0.231^{\mathrm{BC}}$ & $0.196^{\mathrm{C}}$ & $0.274^{\mathrm{AB}}$ & $0.239^{\mathrm{ABC}}$ & $0.250^{\mathrm{ABC}}$ & 0.0120 & $*$ \\
\hline c8 C20:1 & $1.03^{\mathrm{CD}}$ & $1.00^{\mathrm{D}}$ & $0.93^{\mathrm{E}}$ & $1.08^{\mathrm{BC}}$ & $1.09^{\mathrm{B}}$ & $1.07^{\mathrm{BC}}$ & $1.14^{\mathrm{A}}$ & $1.16^{\mathrm{A}}$ & $1.04^{\mathrm{BCD}}$ & $1.03^{\mathrm{BCD}}$ & $1.07^{\mathrm{BC}}$ & $1.10^{\mathrm{B}}$ & 0.026 & $* * *$ \\
\hline c11 C20:1 & $0.428^{\mathrm{D}}$ & $0.471^{\mathrm{BC}}$ & $0.465^{\mathrm{BC}}$ & $0.478^{\mathrm{AB}}$ & $0.438^{\mathrm{CD}}$ & $0.446^{\mathrm{CD}}$ & $0.497^{\mathrm{AB}}$ & $0.516^{\mathrm{A}}$ & $0.442^{\mathrm{CD}}$ & $0.079^{\mathrm{E}}$ & $0.075^{\mathrm{E}}$ & $0.046^{\mathrm{E}}$ & 0.0147 & $* * *$ \\
\hline c9c12c15 C18:3 & $4.69^{\mathrm{D}}$ & $5.20^{\mathrm{C}}$ & $6.54^{\mathrm{A}}$ & $6.09^{\mathrm{B}}$ & $6.07^{\mathrm{B}}$ & $5.99^{\mathrm{B}}$ & $6.11^{\mathrm{B}}$ & $5.51^{\mathrm{C}}$ & $4.60^{\mathrm{D}}$ & $4.52^{\mathrm{D}}$ & $4.63^{\mathrm{D}}$ & $4.72^{\mathrm{D}}$ & 0.380 & $* * *$ \\
\hline
\end{tabular}




\begin{tabular}{|c|c|c|c|c|c|c|c|c|c|c|c|c|c|c|}
\hline c9t11 C18:2 & $4.76^{\mathrm{E}}$ & $5.65^{\mathrm{C}}$ & $8.83^{\mathrm{A}}$ & $8.31^{\mathrm{AB}}$ & $8.52^{\mathrm{AB}}$ & $8.44^{\mathrm{AB}}$ & $8.36^{\mathrm{AB}}$ & $7.97^{\mathrm{B}}$ & $5.62^{\mathrm{CD}}$ & $4.76^{\mathrm{E}}$ & $4.92^{\mathrm{DE}}$ & $4.93^{\mathrm{DE}}$ & 0.409 & $* * *$ \\
\hline Unknown C18:2 conjugated & $0.289^{\mathrm{C}}$ & $0.282^{\mathrm{C}}$ & $0.356^{\mathrm{B}}$ & $0.484^{\mathrm{A}}$ & $0.383^{\mathrm{B}}$ & $0.352^{\mathrm{B}}$ & $0.385^{\mathrm{B}}$ & $0.352^{\mathrm{B}}$ & $0.294^{\mathrm{C}}$ & $0.197^{\mathrm{D}}$ & $0.167^{\mathrm{DE}}$ & $0.146^{\mathrm{E}}$ & 0.0185 & $* * *$ \\
\hline Unknown $\mathrm{C} 18: 2$ conjugated & $0.223^{\mathrm{F}}$ & $0.249^{\mathrm{EF}}$ & $0.372^{\mathrm{CBA}}$ & $0.351^{\mathrm{BCD}}$ & $0.392^{\mathrm{AB}}$ & $0.384^{\mathrm{A}}$ & $0.385^{\mathrm{AB}}$ & $0.382^{\mathrm{ABC}}$ & $0.268^{\mathrm{EF}}$ & $0.275^{\mathrm{E}}$ & $0.324^{\mathrm{D}}$ & $0.344^{\mathrm{CD}}$ & 0.0283 & $* * *$ \\
\hline c11c14 C20:2 & $0.103^{\mathrm{F}}$ & $0.116^{\mathrm{EF}}$ & $0.125^{\mathrm{E}}$ & $0.125^{\mathrm{EF}}$ & $0.126^{\mathrm{EF}}$ & $0.170^{\mathrm{D}}$ & $0.227^{\mathrm{C}}$ & $0.222^{\mathrm{C}}$ & $0.188^{\mathrm{D}}$ & $0.349^{\mathrm{B}}$ & $0.338^{\mathrm{B}}$ & $0.375^{\mathrm{A}}$ & 0.0091 & $* * *$ \\
\hline $\mathrm{C} 22: 0$ & $0.617^{\mathrm{DE}}$ & $0.622^{\mathrm{CD}}$ & $0.623^{\mathrm{CD}}$ & $0.678^{\mathrm{AB}}$ & $0.583^{\mathrm{EF}}$ & $0.536^{\mathrm{G}}$ & $0.709^{\mathrm{A}}$ & $0.712^{\mathrm{A}}$ & $0.569^{\mathrm{FG}}$ & $0.665^{\mathrm{BC}}$ & $0.618^{\mathrm{DE}}$ & $0.652^{\mathrm{BCD}}$ & 0.0320 & $* * *$ \\
\hline c8c11c14 C20:3 & $0.764^{\mathrm{AB}}$ & $0.768^{\mathrm{AB}}$ & $0.753^{\mathrm{AB}}$ & $0.745^{\mathrm{ABC}}$ & $0.699^{\mathrm{CD}}$ & $0.729^{\mathrm{BC}}$ & $0.749^{\mathrm{AB}}$ & $0.772^{\mathrm{A}}$ & $0.685^{\mathrm{D}}$ & $0.764^{\mathrm{AB}}$ & $0.764^{\mathrm{AB}}$ & $0.782^{\mathrm{A}}$ & 0.0265 & $* * *$ \\
\hline c13 C22:1 & 0.115 & 0.131 & 0.149 & 0.136 & 0.123 & 0.125 & 0.128 & 0.221 & 0.175 & 0.167 & 0.246 & 0.150 & 0.0266 & $\dagger$ \\
\hline c11c14c17 C20:3 & $0.078^{\mathrm{E}}$ & $0.089^{\mathrm{CDE}}$ & $0.111^{\mathrm{CD}}$ & $0.118^{\mathrm{C}}$ & $0.116^{\mathrm{CD}}$ & $0.109^{\mathrm{CDE}}$ & $0.117^{\mathrm{C}}$ & $0.101^{\mathrm{CDE}}$ & $0.083^{\mathrm{DE}}$ & $0.189^{\mathrm{B}}$ & $0.221^{\mathrm{B}}$ & $0.307^{\mathrm{A}}$ & 0.0155 & $* * *$ \\
\hline c5c8c11c14 C20:4 & $0.98^{\mathrm{BC}}$ & $0.99^{\mathrm{BC}}$ & $0.97^{\mathrm{CD}}$ & $0.96^{\mathrm{CD}}$ & $0.91^{\mathrm{D}}$ & $0.95^{\mathrm{CD}}$ & $1.00^{\mathrm{BC}}$ & $1.03^{\mathrm{AB}}$ & $0.91^{\mathrm{D}}$ & $1.09^{\mathrm{A}}$ & $1.10^{\mathrm{A}}$ & $1.05^{\mathrm{AB}}$ & 0.033 & $* * *$ \\
\hline c13c16 C22:2 & $0.364^{\mathrm{FG}}$ & $0.398^{\mathrm{EF}}$ & $0.521^{\mathrm{A}}$ & $0.470^{\mathrm{BCD}}$ & $0.493^{\mathrm{AB}}$ & $0.426^{\mathrm{DE}}$ & $0.458^{\mathrm{BC}}$ & $0.435^{\mathrm{CDE}}$ & $0.340^{\mathrm{G}}$ & $0.433^{\mathrm{CDE}}$ & $0.467^{\mathrm{BC}}$ & $0.459^{\mathrm{BC}}$ & 0.0233 & $* * *$ \\
\hline c5c8c11c14c17 C20:5 & $0.502^{\mathrm{CD}}$ & $0.513^{\mathrm{CD}}$ & $0.636^{\mathrm{A}}$ & $0.641^{\mathrm{AB}}$ & $0.659^{\mathrm{A}}$ & $0.644^{\mathrm{AB}}$ & $0.647^{\mathrm{A}}$ & $0.611^{\mathrm{B}}$ & $0.535^{\mathrm{C}}$ & $0.515^{\mathrm{CD}}$ & $0.488^{\mathrm{D}}$ & $0.484^{\mathrm{D}}$ & 0.0327 & ** \\
\hline $\mathrm{C} 24: 0$ & $0.360^{\mathrm{E}}$ & $0.366^{\mathrm{DE}}$ & $0.377^{\mathrm{CDE}}$ & $0.428^{\mathrm{A}}$ & $0.411^{\mathrm{AB}}$ & $0.425^{\mathrm{A}}$ & $0.423^{\mathrm{A}}$ & $0.410^{\mathrm{AB}}$ & $0.333^{\mathrm{F}}$ & $0.409^{\mathrm{AB}}$ & $0.388^{\mathrm{CD}}$ & $0.394^{\mathrm{BC}}$ & 0.0192 & $* * *$ \\
\hline c13c16c19 C22:3 & $0.071^{\mathrm{E}}$ & $0.078^{\mathrm{DE}}$ & $0.080^{\mathrm{DE}}$ & $0.091^{\mathrm{CDE}}$ & $0.079^{\mathrm{DE}}$ & $0.109^{\mathrm{C}}$ & $0.095^{\mathrm{CDE}}$ & $0.096^{\mathrm{CD}}$ & $0.075^{\mathrm{DE}}$ & $0.184^{\mathrm{A}}$ & $0.154^{\mathrm{B}}$ & $0.163^{\mathrm{AB}}$ & 0.0071 & $* * *$ \\
\hline c7c10c13c16 C22:4 & $0.129^{\mathrm{CDE}}$ & $0.148^{\mathrm{CD}}$ & $0.124^{\mathrm{DE}}$ & $0.118^{\mathrm{DEF}}$ & $0.102^{\mathrm{EFG}}$ & $0.181^{\mathrm{BC}}$ & $0.081^{\mathrm{FG}}$ & $0.071^{\mathrm{G}}$ & $0.090^{\mathrm{FG}}$ & $0.231^{\mathrm{A}}$ & $0.242^{\mathrm{A}}$ & $0.205^{\mathrm{AB}}$ & 0.0155 & $* * *$ \\
\hline $\mathrm{c} 7 \mathrm{c} 10 \mathrm{c} 13 \mathrm{c} 16 \mathrm{c} 19 \mathrm{C} 22: 5$ & $0.786^{\mathrm{D}}$ & $0.787^{\mathrm{D}}$ & $0.878^{\mathrm{BC}}$ & $0.895^{\mathrm{BC}}$ & $0.934^{\mathrm{AB}}$ & $0.919^{\mathrm{ABC}}$ & $0.980^{\mathrm{A}}$ & $0.960^{\mathrm{AB}}$ & $0.937^{\mathrm{AB}}$ & $0.856^{\mathrm{CD}}$ & $0.918^{\mathrm{BC}}$ & $0.881^{\mathrm{BC}}$ & 0.0441 & $* * *$ \\
\hline c4c7c10c13c16c19 C22:6 & 0.059 & 0.058 & 0.067 & 0.066 & 0.066 & 0.059 & 0.132 & 0.079 & 0.061 & 0.070 & 0.063 & 0.058 & 0.0087 & $\mathrm{~ns}$ \\
\hline
\end{tabular}

${ }^{a}$ In September, there was a missing sample of free-range milk in the analysis of basic composition and the mean on this set of parameters was calculated from nine samples

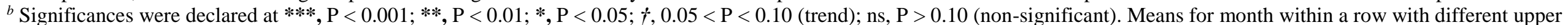
case letters are significantly different according to Fisher's Least Significant Difference test $(\mathrm{P}<0.05)$ 